\title{
QUALITY OF WATER IN THE RED RIVER ALLUVIAL AQUIFER, POOL 1, RED RIVER WATERWAY AREA, Vick, LOUISIANA
}

By Charles W. Smoot, Ronald C. Seanor, and G.F. Huff

U.S. Geological Survey

Water-Resources Investigations Report 93-4184

Prepared in cooperation with the

U.S. ARMY CORPS OF ENGINEERS, VICKSBURG DISTRICT

Baton Rouge, Louisiana 
U.S. DEPARTMENT OF THE INTERIOR

BRUCE BABBITT, Secretary

U.S. GEOLOGICAL SURVEY

Gordon P. Eaton, Director

For additional information write to:

Copies of this report can be purchased from:

District Chief

U.S. Geological Survey

U.S. Geological Survey

3535 S. Sherwood Forest Blvd., Suite 120

Baton Rouge, LA 70816

Earth Science Information Center

Open-File Reports Section

Box 25286, MS 517

Denver Federal Center

Denver, CO 80225

Chief, Engineering Division

U.S. Army Corps of Engineers

Vicksburg District

P.O. Box 60, CELMK-ED-FT

Vicksburg, MS 39181 


\section{CONTENTS}

Page

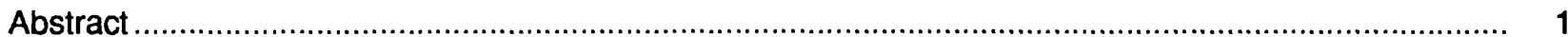

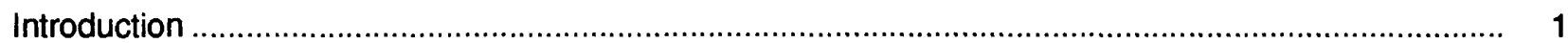

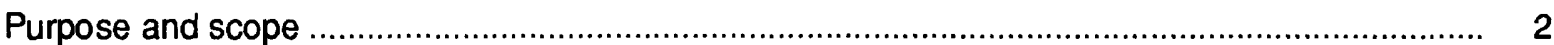

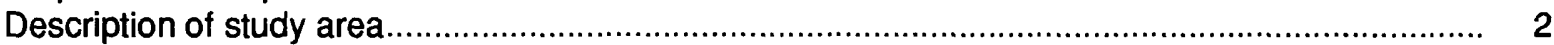

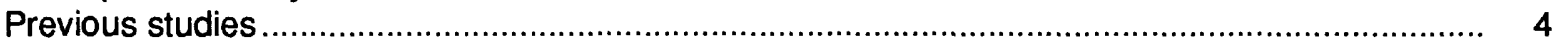

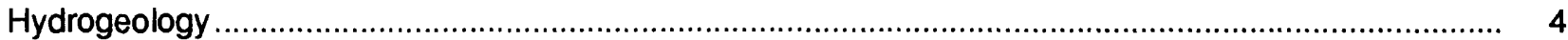

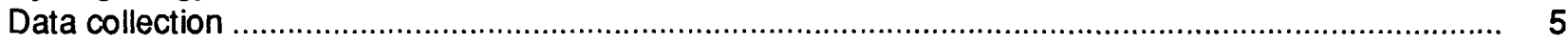

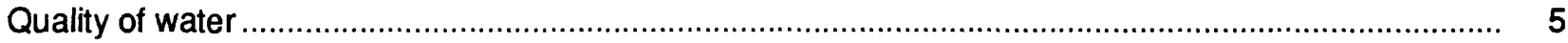

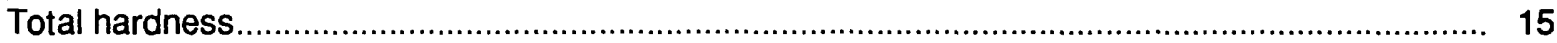

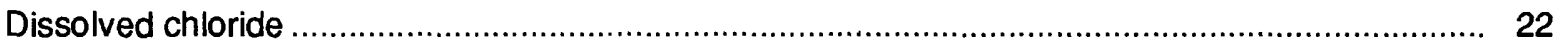

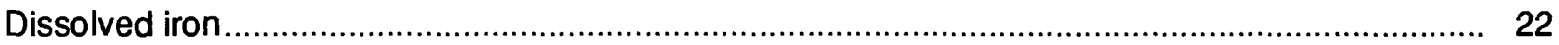

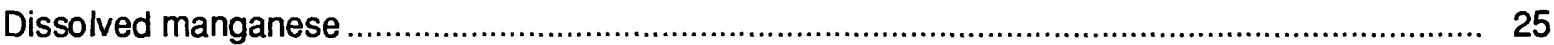

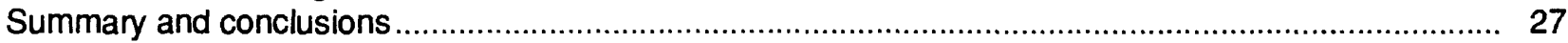

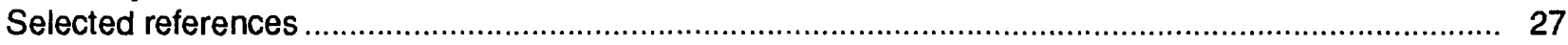

\section{ILLUSTRATIONS}

Figure 1. Map showing location of pool 1 study area and selected wells completed in the Red River alluvial aquifer, Louisiana....

2-19. Graphs showing total hardness and concentrations of dissolved chloride, iron, and manganese in water from well:

2. Av-153 completed in the Red River alluvial aquifer, from pre-construction (1974-78) to post-construction (1984-92) of Lock and Dam 1 on the Red River, La.

3. Av-331 completed in the Red River alluvial aquifer, during the pre-construction (1974-78) and post-construction (1984-92) periods of Lock and Dam 1 on the Red River, La.

4. Av-334 completed in the Red River alluvial aquifer, from pre-construction (1974-78) to post-construction (1984-92) of Lock and Dam 1 on the Red River, La.

5. Av-339 completed in the Red River alluvial aquifer, during the pre-construction (1974-78) and post-construction (1984-92) periods of Lock and Dam 1 on the Red River, La.......

6. Av-364 completed in the Red River alluvial aquifer, during pre-construction (1974-78) of Lock and Dam 1 on the Red River, La

7. Av-370 completed in the Red River alluvial aquifer, from pre-construction (1974-78) to post-construction (1984-92) of Lock and Dam 1 on the Red River, La

8. Av-371 completed in the Red River alluvial aquifer, from pre-construction (1974-78) to post-construction (1984-92) of Lock and Dam 1 on the Red River, La...

9. Av-372A completed in the Red River alluvial aquifer, from pre-construction (1974-78) to post-construction (1984-92) of Lock and Dam 1 on the Red River, La.

10. Av-381 completed in the Red River alluvial aquifer, from pre-construction (1976-78) to post-construction (1984-92) of Lock and Dam 1 on the Red River, La.

11. Av-382 completed in the Red River alluvial aquifer, from pre-construction (1976-78) to post-construction (1984-92) of Lock and Dam 1 on the Red River, La.................... 10

12. Ct-74 completed in the Red River alluvial aquifer, from pre-construction (1974-78) to post-construction (1984-92) of Lock and Dam 1 on the Red River, La....

13. Ct-75 completed in the Red River alluvial aquifer, from pre-construction (1974-78) to post-construction (1984-92) of Lock and Dam 1 on the Red River, La.

14. Ct-81 completed in the Red River alluvial aquifer, from pre-construction (1974-78) to post-construction (1984-92) of Lock and Dam 1 on the Red River, La. 
Figures--Continued

Page

15. Ct-96 completed in the Red River alluvial aquifer, during the pre-construction (1974-78) and post-construction (1984-92) periods of Lock and Dam 1 on the Red River, La.

16. R-733 completed in the Red River alluvial aquifer, during the construction (1980-83) and post-construction (1984-92) periods of Lock and Dam 1 on the Red River, La..... 13

17. R-744 completed in the Red River alluvial aquifer, from pre-construction (1974-78) to post-construction (1984-92) of Lock and Dam 1 on the Red River, La.

18. R-963 completed in the Red River alluvial aquifer, from pre-construction (1974-78) to post-construction (1984-92) of Lock and Dam 1 on the Red River, La.

19. R-1102 completed in the Red River alluvial aquifer, from pre-construction (1974-78) to post-construction (1984-92) of Lock and Dam 1 on the Red River, La

20. Map showing changes in median values of total hardness of water from wells completed in the Red River alluvial aquifer, from pre-construction (1974-78) to postconstruction (1984-92) of Lock and Dam 1 on the Red River, La.

21. Map showing changes in median concentration of dissolved chloride in water from wells completed in the Red River alluvial aquifer, from pre-construction (1974-78) to post-construction (1984-92) of Lock and Dam 1 on the Red River, La.

22. Map showing changes in median concentration of dissolved iron in water from wells completed in the Red River alluvial aquifer, from pre-construction (1974-78) to post-construction (1984-92) of Lock and Dam 1 on the Red River, La

23. Map showing changes in median concentration of dissolved manganese in water from wells completed in the Red River alluvial aquifer, from pre-construction (1974-78) to post-construction (1984-92) of Lock and Dam 1 on the Red River, La.

\section{TABLES}

Table 1. Summary of chemical and physical analyses of water from wells completed in the Red River alluvial aquifer, Louisiana, 1965-92. at back

2. Statistical analysis of total hardness and concentrations of dissolved chloride, iron, and manganese in water from selected wells completed in the Red River alluvial aquifer, during pre-construction (1974-78) and post-construction (1984-92) periods of Lock and Dam 1 on the Red River, Louisiana...

3. Summary of changes in median values of total hardness and median concentrations of dissolved chloride, iron, and manganese in water from selected wells completed in the Red River alluvial aquifer, from pre-construction (1974-78) to postconstruction (1984-92) of Lock and Dam 1 on the Red River, Louisiana...... 
CONVERSION FACTORS, VERTICAL DATUM, AND ABBREVIATED WATER-QUALITY UNITS

\begin{tabular}{rcl}
\hline Multiply & By & To obtain \\
\hline foot (ft) & 0.3048 & meter \\
inch (in.) & 25.4 & millimeter \\
mile (mi) & 1.609 & kilometer \\
million gallons per day (Mgal/d) & 0.04381 & cubic meters per second \\
\hline
\end{tabular}

Temperature in degrees Celsius $\left({ }^{\circ} \mathrm{C}\right)$ can be converted to degrees Fahrenheit $\left({ }^{\circ} \mathrm{F}\right)$ as follows: ${ }^{\circ} \mathrm{F}=1.8\left({ }^{\circ} \mathrm{C}\right)+32$.

Sea level: In this report, "sea level" refers to the National Geodetic Vertical Datum of 1929 (NGVD of 1929)-a geodetic datum derived from a general adjustment of the first-order level nets of both the United States and Canada, formerly called Sea Level Datum of 1929.
Abbreviated water-quality units:
micrograms per liter $(\mu \mathrm{g} / \mathrm{L})$
microsiemens per centimeter at 25 degrees Celsius $(\mu \mathrm{S} / \mathrm{cm})$
milligrams per liter $(\mathrm{mg} / \mathrm{L})$ 


\title{
QUALITY OF WATER IN THE RED RIVER ALLUVIAL AQUIFER, POOL 1, RED RIVER WATERWAY AREA, Vick, LOUISIANA
}

\author{
By Charles W. Smoot, Ronald C. Seanor, and G.F. Huff
}

\begin{abstract}
Water-quality changes in the Red River alluvial aquifer within the area affected by pool 1 near Vick, Louisiana, were monitored during pre-construction (1974-78) and post-construction (1984-92) of Lock and Dam 1. Changes greater or less than background values have occurred in an area within 2 miles of Lock and Dam 1, and in one well located about 10 miles west of Lock and Dam 1.

Comparison between the pre-construction and post-construction water-quality analyses indicated the total hardness as calcium carbonate and concentrations of dissolved chloride, iron, and manganese generally have decreased in the Red River alluvial aquifer south of the Red River and near Lock and Dam 1. The maximum decrease of the median total hardness as calcium carbonate was from 730 to $330 \mathrm{mg} / \mathrm{L}$ (milligrams per liter), dissolved chloride from 77 to $46 \mathrm{mg} / \mathrm{L}$, dissolved iron from 18 to $6.9 \mathrm{mg} / \mathrm{L}$, and dissolved manganese from 1.4 to $0.56 \mathrm{mg} / \mathrm{L}$. Analyses of water from wells west of Lock and Dam 1 indicated an increase of the median total hardness as calcium carbonate was from 200 to $260 \mathrm{mg} / \mathrm{L}$, and dissolved iron concentration was from 0.33 to $1.4 \mathrm{mg} / \mathrm{L}$. North of the river and 1 mile west of Lock and Dam 1, the median concentration of dissolved chloride increased from 45 to $130 \mathrm{mg} / \mathrm{L}$ in water from one well, and median total hardness as calcium cabonate and concentrations of dissolved iron and manganese also increased. Because well $\mathrm{Ct}-74$ is completed in a sand that is in contact with a saltwater sand of Tertiary age, this increase is probably a temporal increase due to upconing after lowering the water level in the alluvial aquifer by pumping of dewatering wells during construction of Lock and Dam 1.
\end{abstract}

\section{INTRODUCTION}

The Red River alluvial aquifer is the only source of fresh ground water within the Red River Valley in the area affected by the impoundment of water by Lock and Dam 1 (pool 1). The structure was completed on the Red River waterway near Vick, Louisiana, in March 1984. The aquifer provides water for irrigation and domestic use, but the water for public supply or industrial use requires treatment (reduction or removal of hardness and iron) before use. In addition, water from the aquifer has a relatively low and constant temperature, which makes it suitable for other uses such as industrial cooling.

The Red River alluvial aquifer is an important resource in the valley, and knowledge of the effects of the construction and operation of Lock and Dam 1 on its quality of water is needed. In response to this need, the U.S. Geological Survey, in cooperation with the U.S. Army Corps of 
Engineers, began a study in 1974 to determine the quality of water in the aquifer. The study included the systematic collection and analysis of selected water-quality samples from the Red River alluvial aquifer during the following periods: (1) Prior to construction (pre-construction, 1974-78), (2) during construction (1979-83), and (3) after construction (post-construction, 1984-92) of a lock and dam structure on the Red River waterway. In 1978, 64 wells with a combined pumping rate of more than $100 \mathrm{Mgal} / \mathrm{d}$ were installed to dewater the Red River alluvial aquifer at the construction site for Lock and Dam 1. About half of these wells were pumped, most of the time, from January 1979 to March 1984 (Adolfo Ramirez, U.S. Army Corps of Engineers, oral commun., 1992).

\section{Purpose and Scope}

This report describes the effects of construction and operation of Lock and Dam 1 on the Red River on water quality in the Red River alluvial aquifer in the pool 1 area. Specifically, water-quality changes were evaluated from analyses of hardness and three constituents in water from wells completed in the Red River alluvial aquifer. The three constituents are dissolved chloride, dissolved iron, and dissolved manganese. The changes were determined by statistical analysis of data collected from 1974 to 1978 (pre-construction) and from 1984 to 1992 (post-construction). Graphs also were used to evaluate water-quality changes in the aquifer. The graphs illustrate the changes from 1974 to 1992 in values of total hardness and concentrations of dissolved chloride, iron, and manganese in selected wells.

Results of an extensive suite of water-quality analyses of water samples collected from 88 wells in the pool 1 area from 1974 to 1992 also are tabulated. These water-quality analyses establish a broad water-quality data base for the Red River alluvial aquifer. Periodic sampling of 18 of these wells in the study area was continued through 1990 and sampling of 5 of these wells was continued through 1992 to document the quality of water in the Red River alluvial aquifer during the preconstruction, construction, and post-construction periods of Lock and Dam 1. Water-quality analyses for samples collected from 18 selected wells completed in the Red River alluvial aquifer (located between Lock and Dams 1 and 2) are presented in a table. Analyses for water-quality samples collected prior to 1974 also are included in this table. All data are on file at the U.S. Geological Survey.

\section{Description of Study Area}

The pool 1 study area (fig. 1) for this report is within the Red River Valley in the State of Louisiana and extends from Lock and Dam 1, in Catahoula Parish, upstream to Lock and Dam 2, in Rapides Parish. Lock and Dam 1 is located about 10 mi upstream (west) of the confluence of the Black and Red Rivers. Lock and Dam 1 is located about 40 mi downstream from Lock and Dam 2. The pool 1 study area includes parts of Avoyelles, Catahoula, and Rapides Parishes. Normal design operating conditions for Lock and Dam 1 call for an upstream pool altitude of $40 \mathrm{ft}$ and a downstream river altitude of about $4 \mathrm{ft}$ (Smoot and Martin, 1991, sheet 1).

The flood plain in this area ranges from $10 \mathrm{mi}$ to more than $20 \mathrm{mi}$ wide. The altitude of land surface in the valley ranges from an average of $40 \mathrm{ft}$ in Avoyelles Parish to an average of $65 \mathrm{ft}$ above sea level in southeastern Rapides Parish. The annual precipitation ranges from 45 to 65 in. The primary land use is agriculture. 


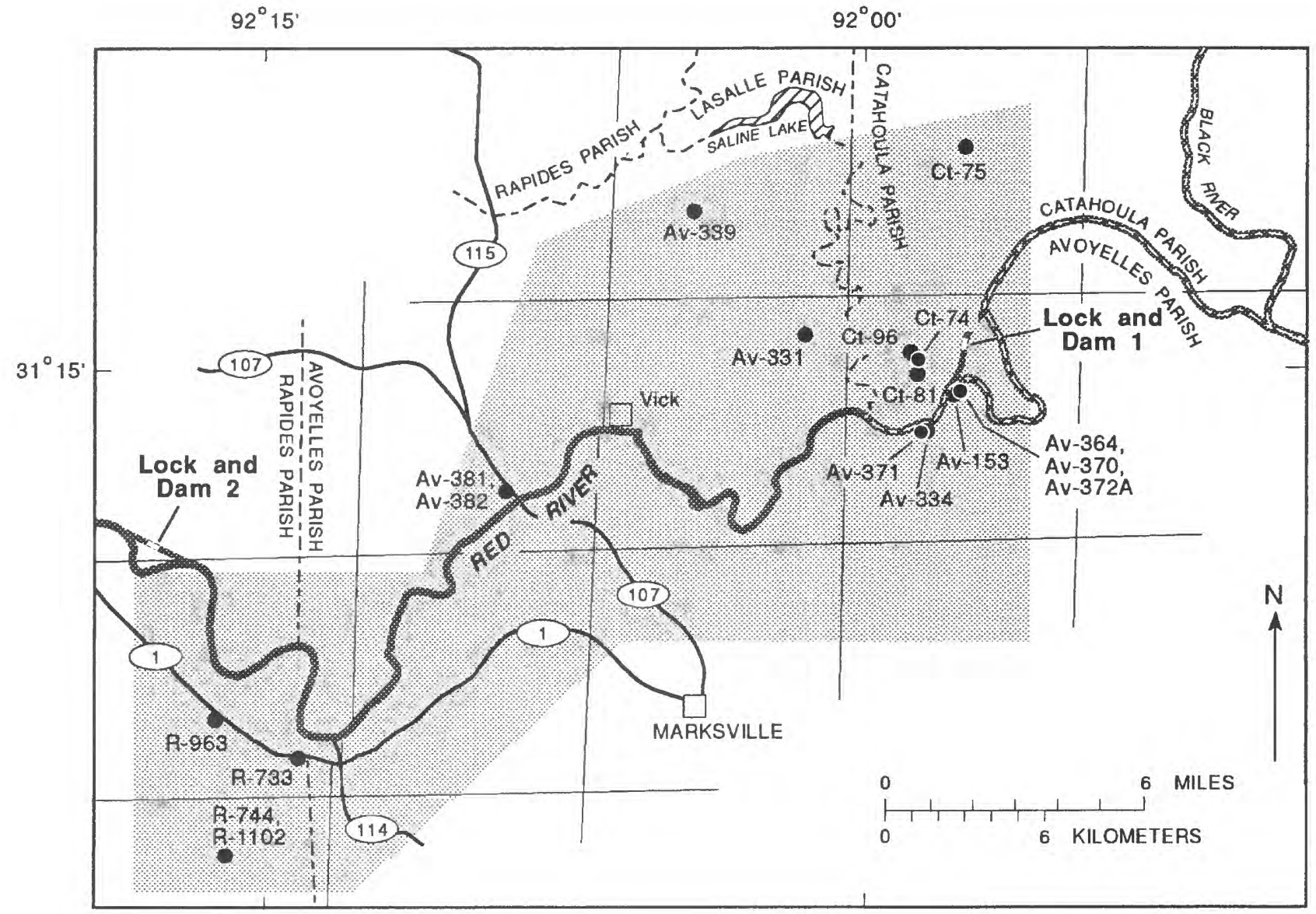

T. $4 \mathrm{~N}$.

T. $3 \mathrm{~N}$

T. $2 \mathrm{~N}$.
R. $2 \mathrm{E}$.
R. $3 E$
A. $4 \mathrm{E}$.
R. $5 \mathrm{E}$.
R. $6 \mathrm{E}$.

\section{EXPLANATION}

\section{AV-339 OBSERVATION WELL AND \\ WELL NUMBER}

STUDY AREA

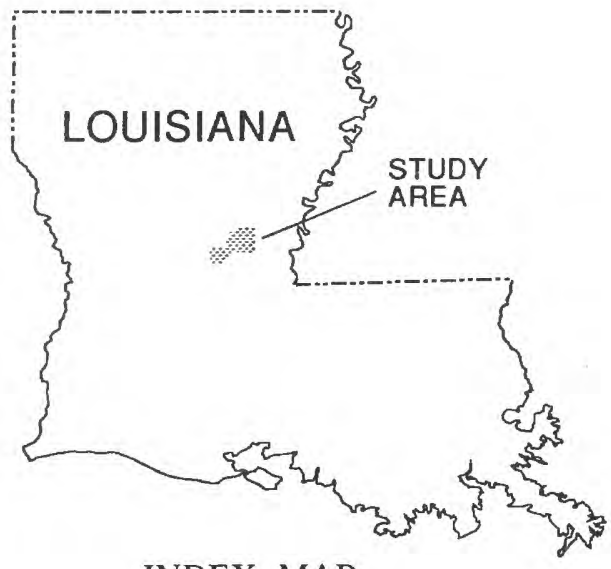

INDEX MAP

Figure 1. Location of pool 1 study area and selected wells completed in the Red River alluvial aquifer, Louisiana. 


\section{Previous Studies}

Water-quality analyses from wells in the Red River alluvial aquifer collected through 1978 were compiled in a report by Whitfield (1980). Also in Whitfield's report are maps showing areal distribution of selected water-quality properties and constituents in water from wells in the aquifer. Tabulation of water-quality data collected from 1978 to 1985 was compiled by Smoot and Guillot (1988). Potentiometric surfaces of the Red River alluvial aquifer, pool 1, are illustrated in a map report by Smoot and Martin (1991).

\section{HYDROGEOLOGY}

The Red River alluvium lies unconformably on the eroded surface of sediments of Tertiary age and ranges from about 100 to $200 \mathrm{ft}$ in thickness within the study area. The alluvium grades downward from clay and silt at the surface to sand and gravel at the base. The overlying surficial clay and silt of Holocene age ranges in thickness from a few feet to more than $50 \mathrm{ft}$.

The lower, coarse-grained section of the alluvium is the Red River alluvial aquifer of Pleistocene age. Gravel is common near the base of the aquifer, and the base of the aquifer generally is marked by the deepest occurrence of gravel (Whitfield, 1980, p. 6). The alluvial aquifer ranges in thickness from 40 to $170 \mathrm{ft}$ within the study area. At places, the Red River alluvial aquifer is hydraulically connected to a sand of Tertiary age, as the drillers log of well Ct-74 indicates (Smoot, 1983, p. 79). Chemical analysis and electric log interpretations indicate the water from this sand is salty.

Water in the alluvial aquifer generally is confined by overlying beds of clay and silt. Water enters the aquifer by infiltration of precipitation through these confining units. Because of large differences of hydraulic conductivity between the confining units and the aquifer, the aquifer acts according to artesian principles. This is confirmed by the low coefficients of storage calculated from pumping tests (Whitfield, 1980, p. 6). Locally, confining units are absent, and water-table conditions prevail. In areas where confining units are thin, water-table conditions can prevail during periods of low water level.

The direction of ground-water flow under average conditions is similar to flow prior to and after construction of the lock and dam structure for most of the study area. However, the postconstruction flow near and upstream from the structure is from the river to the aquifer, a reversal of the pre-construction gradient. The reversal of gradient occurs along the south side of the Red River in Avoyelles Parish, from 4 mi upstream of the structure to about $2 \mathrm{mi}$ east of the Avoyelles-Rapides Parish boundary line. Potentiometric surface maps indicate the direction of flow is away from the river in a band about 3 mi wide when the direction becomes down valley. (See Smoot and Martin, 1991.)

The Red River alluvial aquifer is recharged by infiltration of rainfall in the valley, by lateral movement of water from adjacent hydrogeologic units of Pleistocene and Tertiary age, and by upward movement of water from underlying hydrogeologic units of Tertiary age. Also, the Red River and its major tributaries recharge the aquifer in local zones near the river during high stream stages (Whitfield, 1980, p. 1).

Higher average river stage resulting from the operation of Lock and Dam 1 near Vick, La., can cause higher ground-water levels in the alluvial aquifer. Relation between the higher stages of the river and water quality in the aquifer is not known at this time. However, in places where the waterlevel head in the Red River alluvial aquifer is higher than the underlying saltwater aquifer the 
discharge from the underlying aquifer would be reduced. In these places the chloride concentration can decrease and the hardness and iron concentrations can increase.

\section{DATA COLLECTION}

Within the study area 15 observation wells located at 8 sites have been sampled periodically between 1974 and 1990. From 1974 through 1987 most of these wells were sampled two times per year; once in the spring (high water) and once in the fall (low water). From 1988 to 1990 these wells were sampled once in the spring. Five of these wells (Av-370, Av-372A, Ct-74, Ct-96 and R-963) also were sampled in 1991 and 1992. In addition to these 15 wells, two other wells (Av-331 and Av339) were sampled three times during the period 1974-76, and were sampled two more times during the period 1988-89. Also, well R-733 has been sampled periodical since 1980, but was only sampled three times prior to the start of construction of the lock and dam, with two of these samples being collected in 1958.

All the water-quality samples were collected from observation wells, using a suction-type pump or by pumping with air. All the wells except Av-372A and Ct-96 are finished with 3-foot long screen with a slot size of 0.010 or 0.012 in. Wells Av-372A and Ct-96 are finished with 10- and 5-foot long screens. The samples were collected and processed according to standard methods established for ground-water sampling (American Public Health Association and others, 1980; Brown and others, 1970). Samples were filtered and acidified in the field for later analysis by a U.S. Geological Survey laboratory. Temperature and $\mathrm{pH}$ were determined in the field using procedures described by Wood (1976). Also field determination of alkalinity as calcium carbonate and specific conductance were determined on selected samples. Most of the water-quality samples were analyzed in the laboratory for selected properties and constituents, including total hardness as calcium carbonate and concentrations of dissolved calcium, magnesium, sulfate, chloride, iron, and manganese. The samples were analyzed according to standard methods established for determination of inorganic substances in water (Brown and others, 1970; Fishman and Friedman, 1989).

\section{QUALITY OF WATER}

The analyses for 18 wells completed in the Red River alluvial aquifer are presented in table 1 (at back of this report). Water-quality changes were evaluated for 17 of the 18 wells. Well R-733 was not evaluated because of insufficient data. Changes in total hardness and concentrations of dissolved chloride, iron, and manganese for these 18 wells are shown in graphs (figs. 2-19).

Data are missing for some wells because the screens were incrusted or the water levels in the wells were below the screen setting. Also, concentrations of dissolved iron and manganese are not shown when the sample was collected by pumping with air because aeration alters these constituents.

Median values of total hardness and median concentrations of dissolved chloride, iron, and manganese were calculated using data from pre-construction (1974-78) and post-construction (198492) sampling periods for 18 wells shown in figure 1 . Given relatively small data sets, particularly during the post-construction sampling period, a median value gives a more representative timeaveraged value than would a mean value, by minimizing the effect of outlying data points. A minimum of six data points were required to justify calculation of a median value. Data sets containing less than six points were insufficient for statistical analysis. 


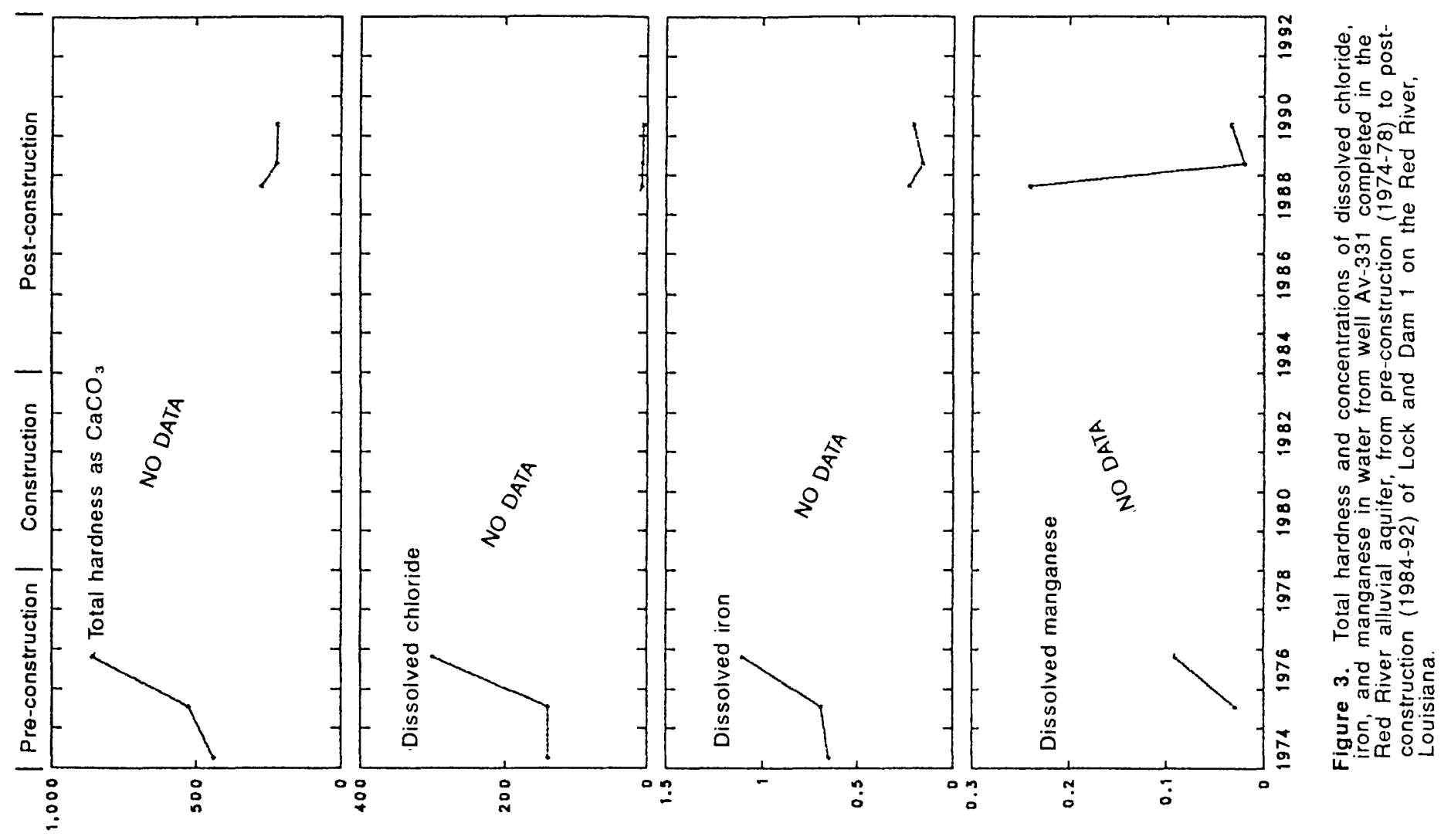

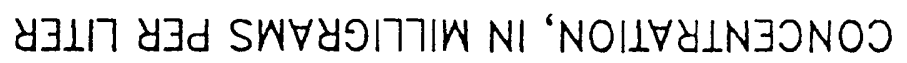

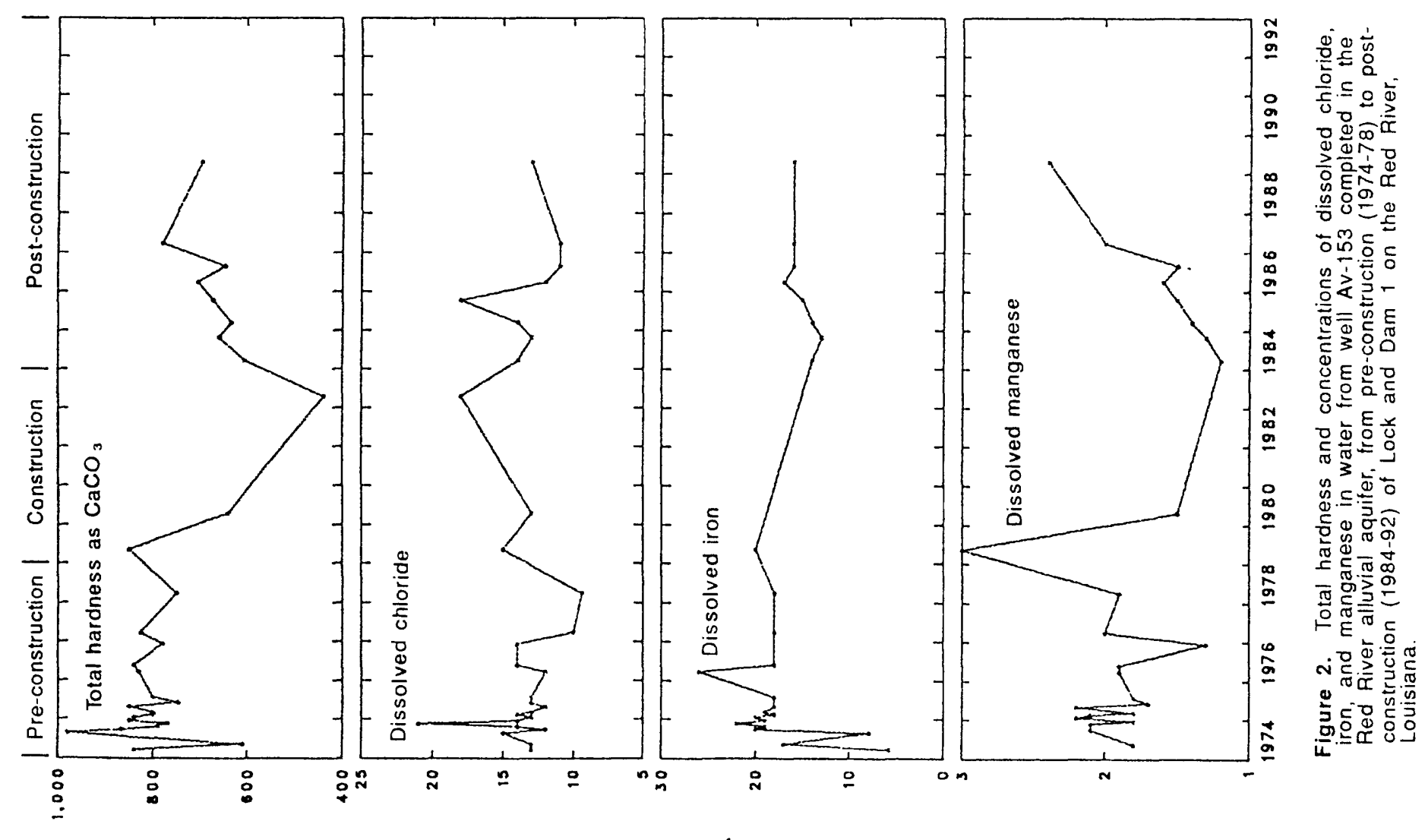

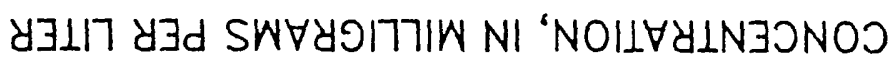



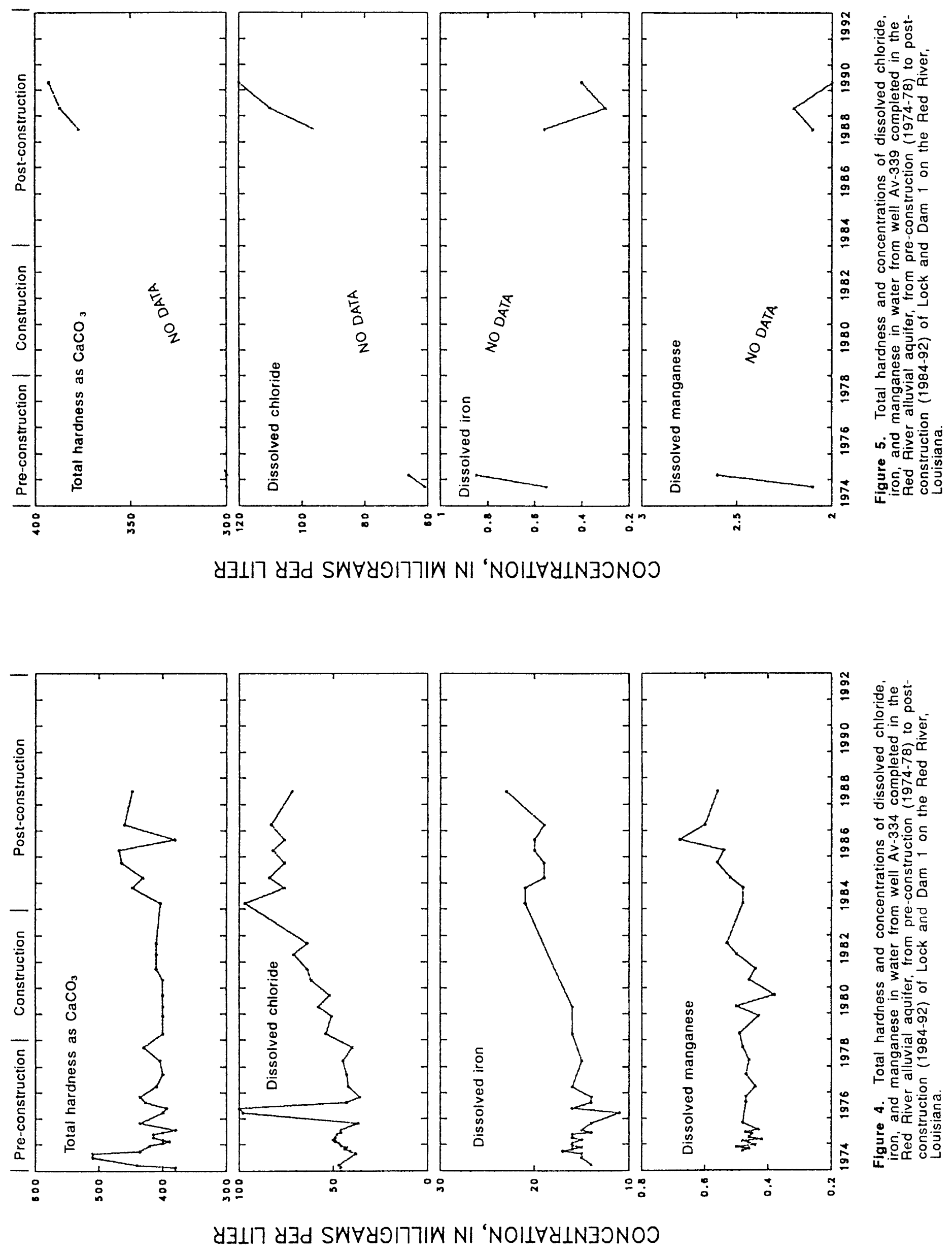


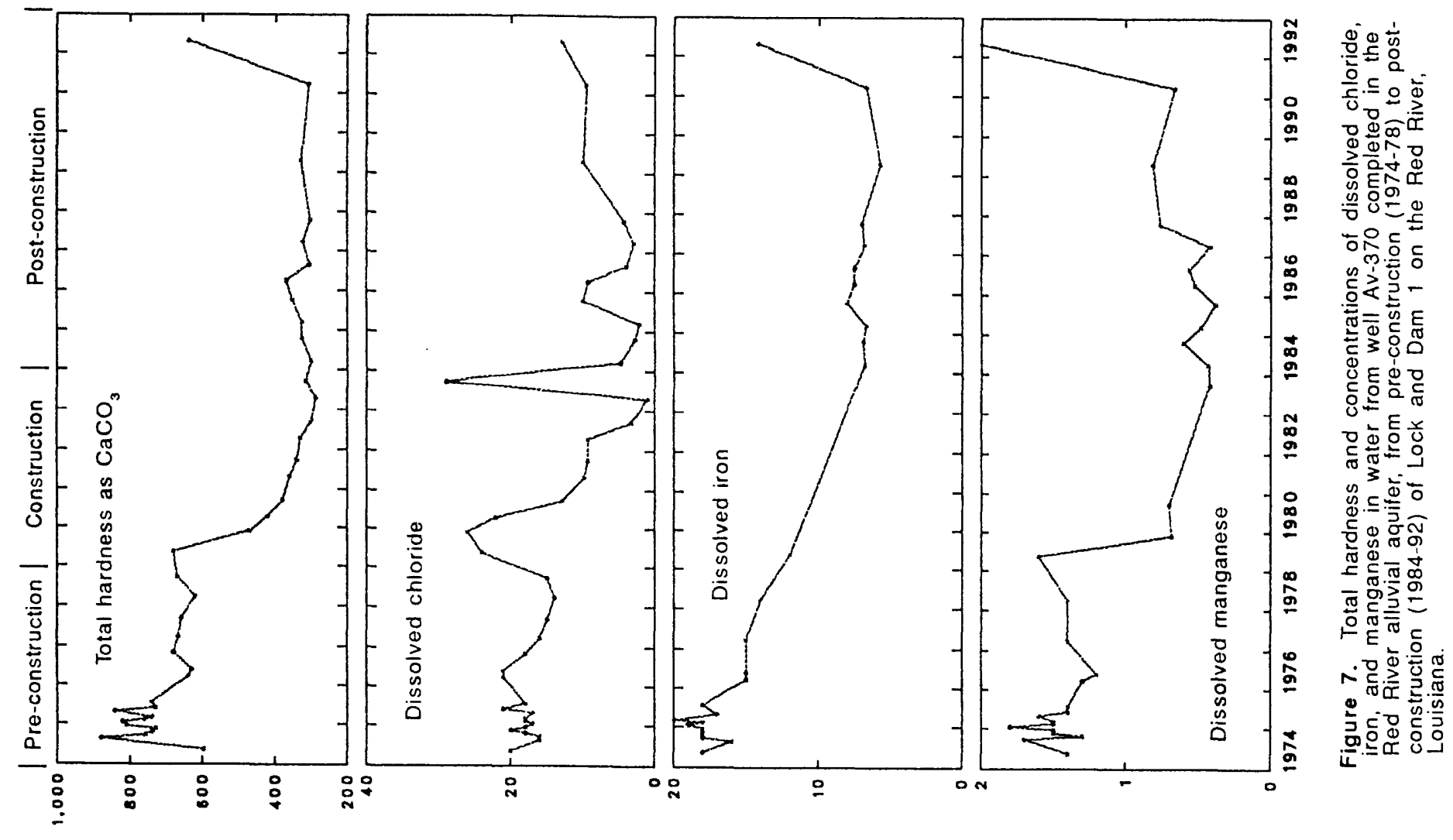

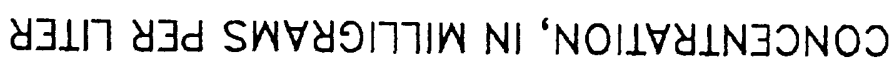
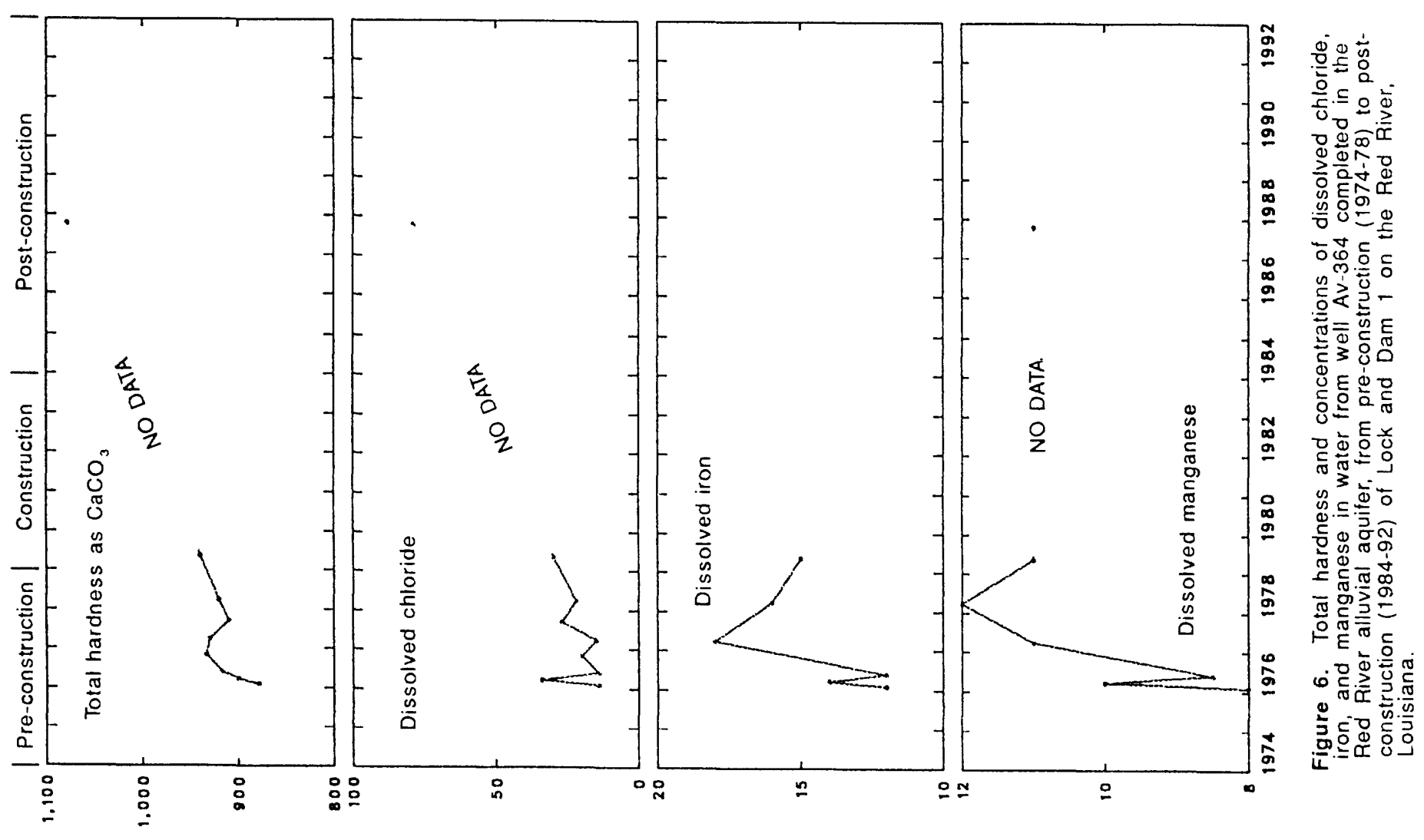

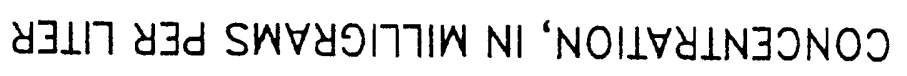




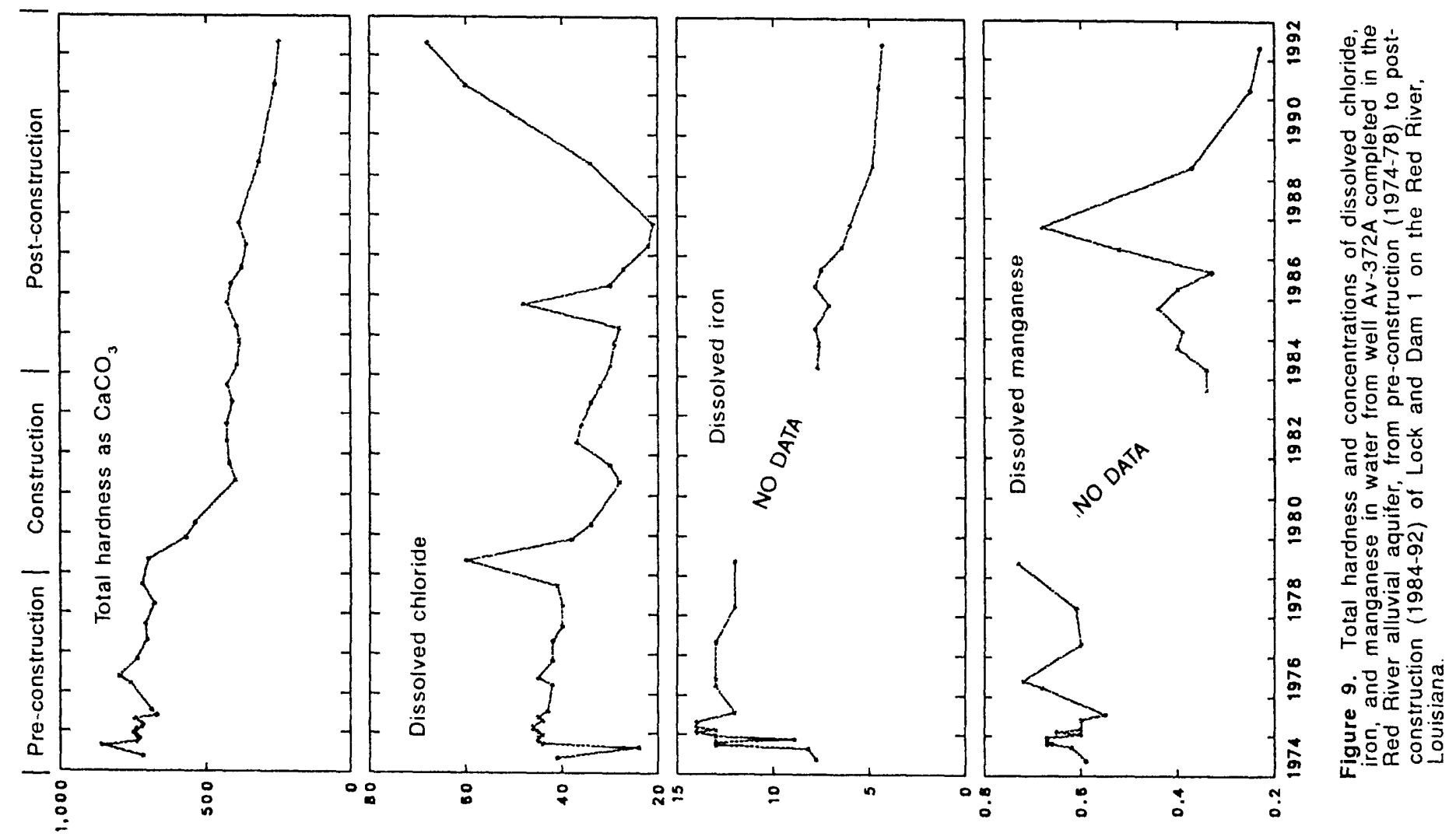

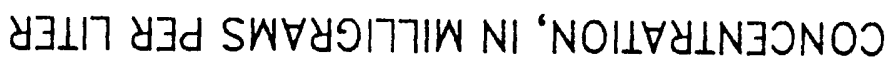
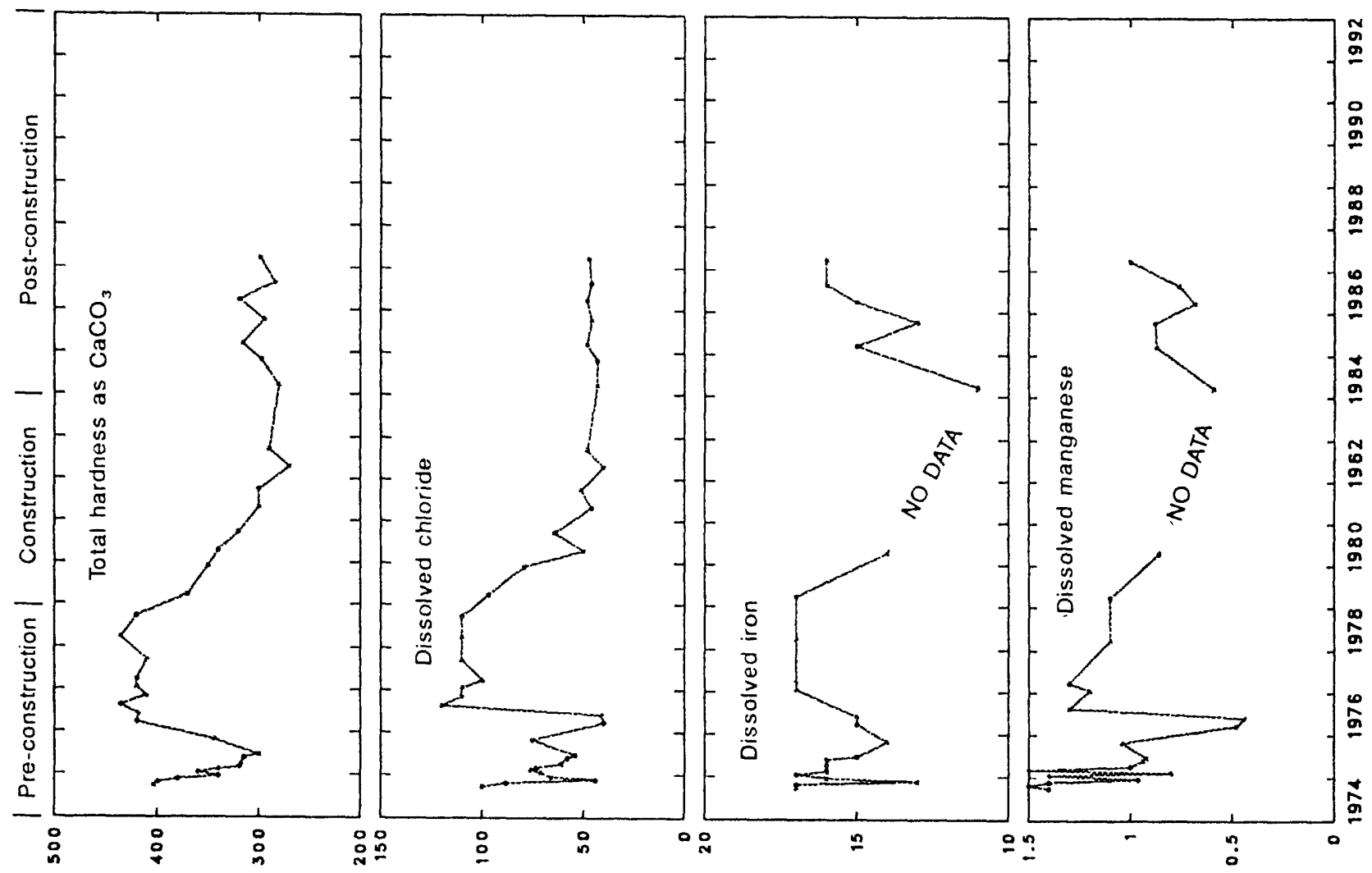

을 혼

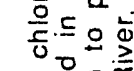

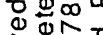

$\geq \frac{0}{2}+0$

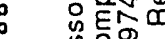

2

훙.응

这安全-

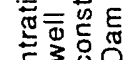
드응ㅎㅁ은

落

-

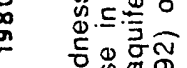

的.

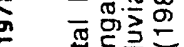

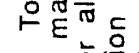

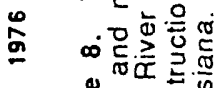

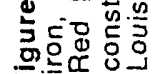




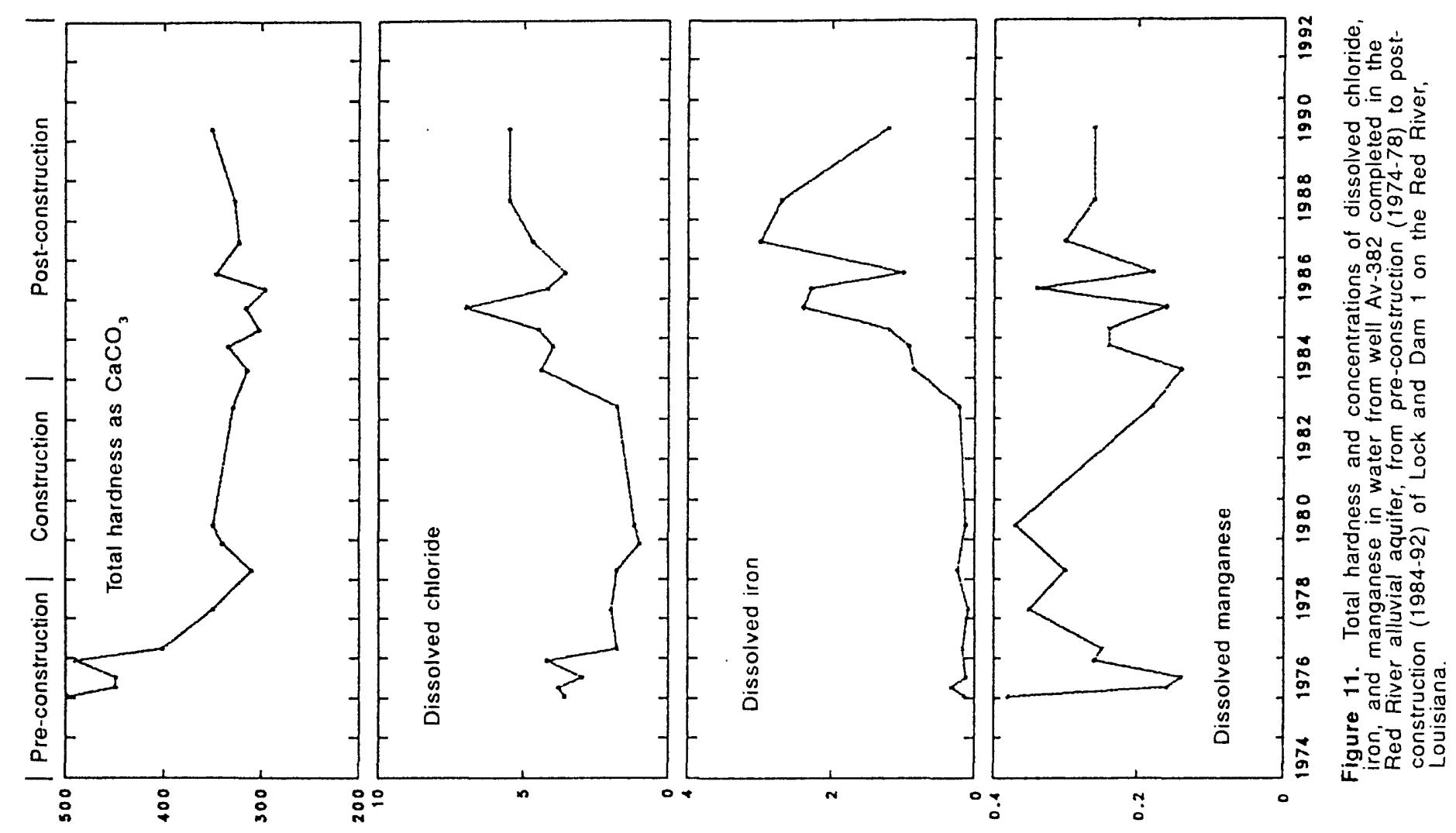

y $\exists \perp 17$ y $y$ d SW

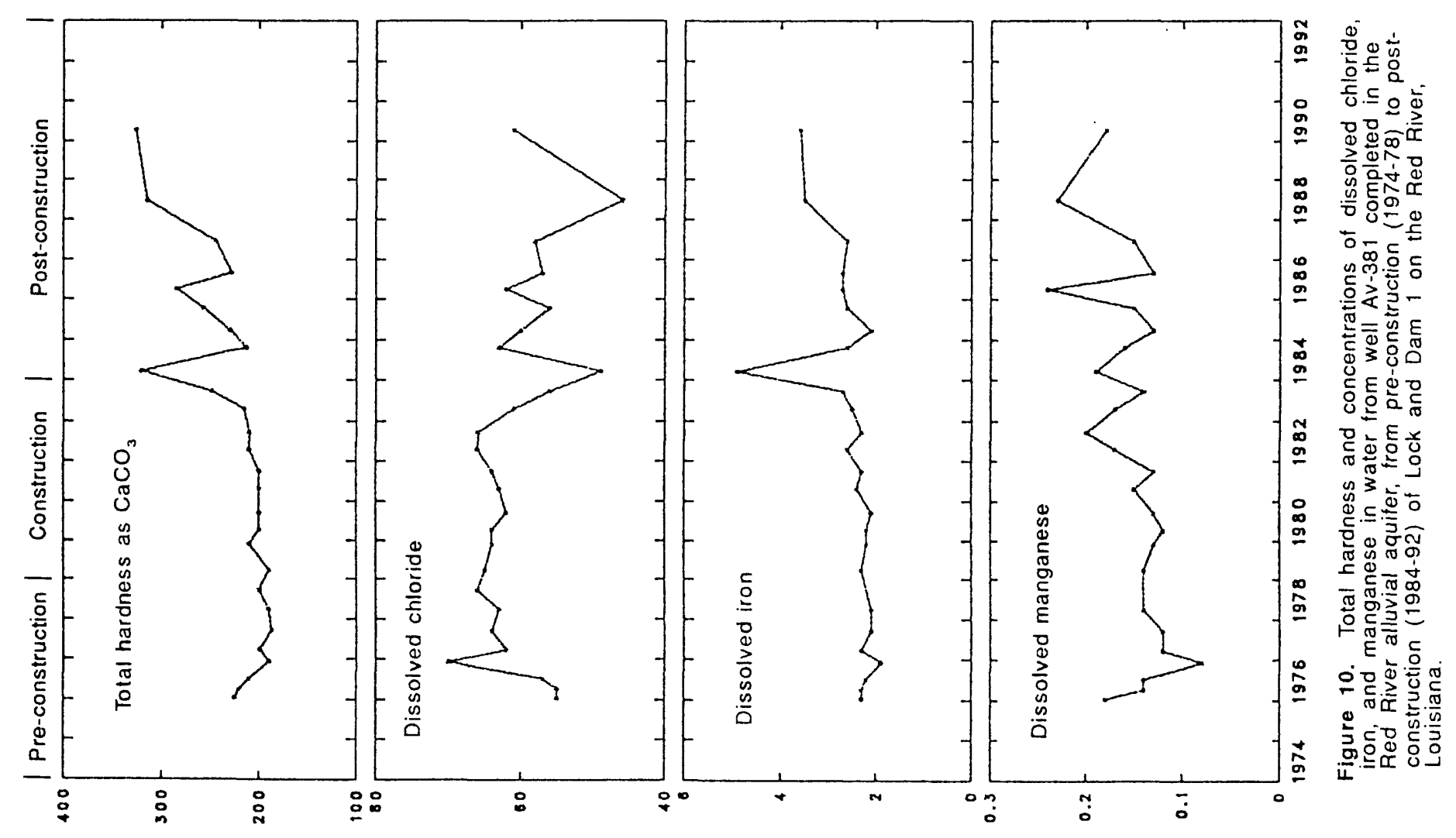

y $\exists I I 7$ d $\mathrm{d}$ d SW 


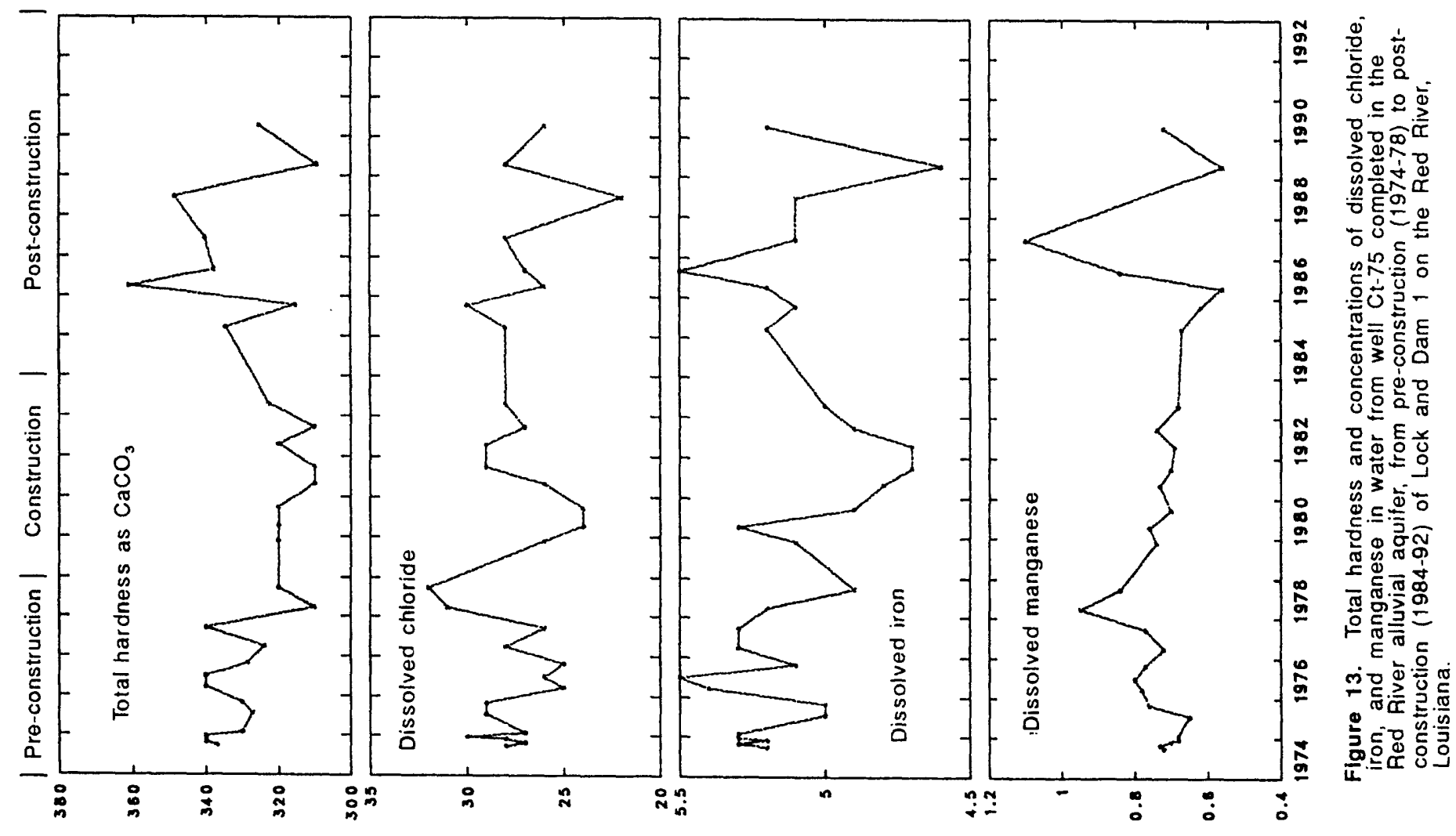

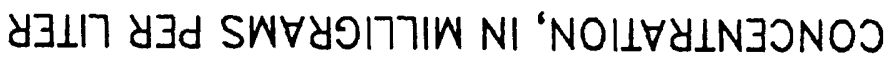
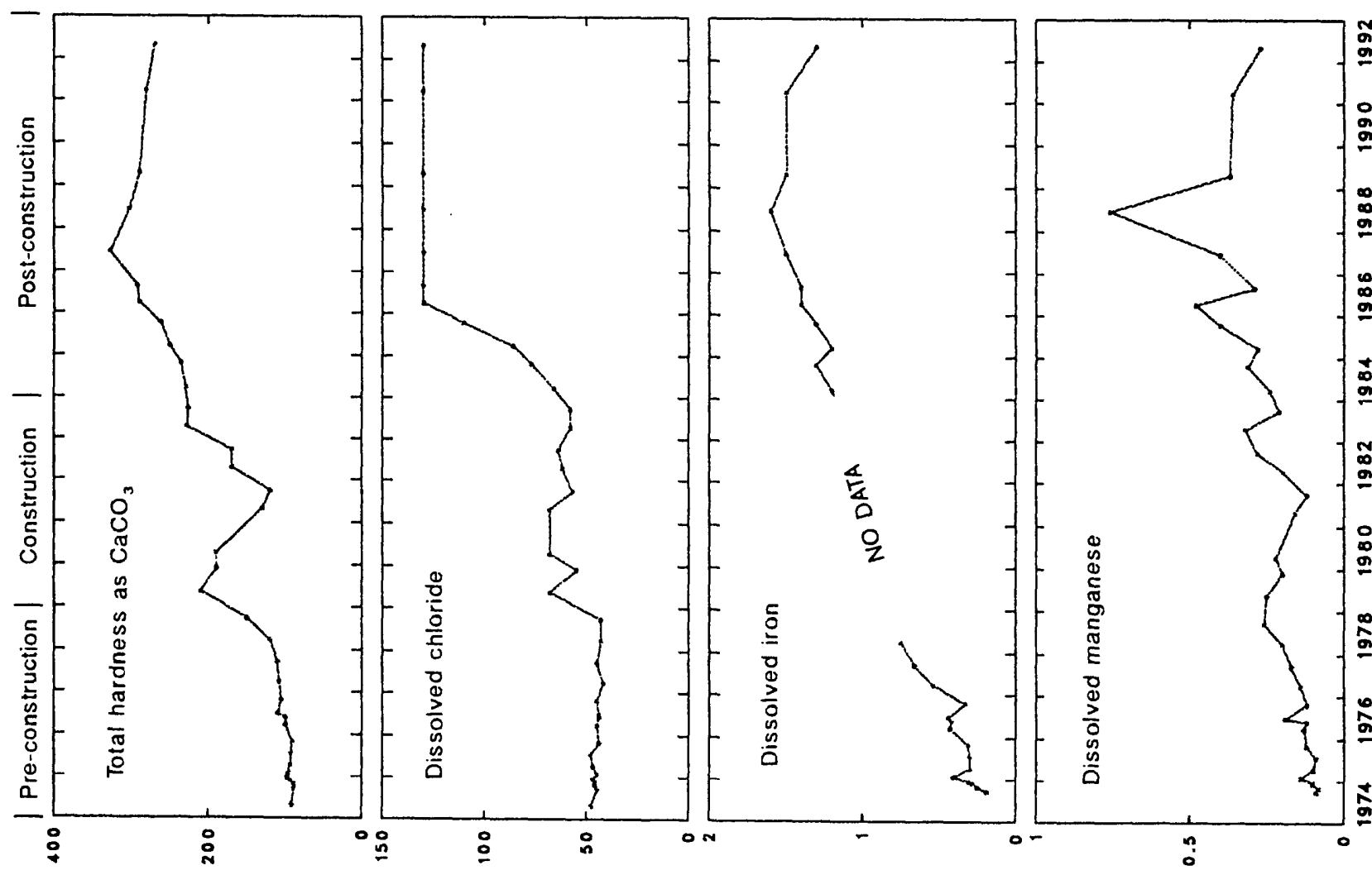

은 을

:

产过

$\infty$ 号这罂

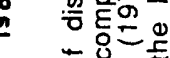

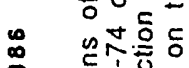

- 은인-

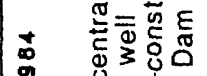

당링혀음

N D

- 要这

\$

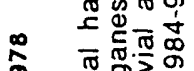

뜡유옹

ह

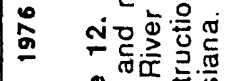

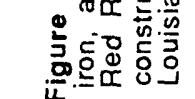

y 3117 y3d SW 

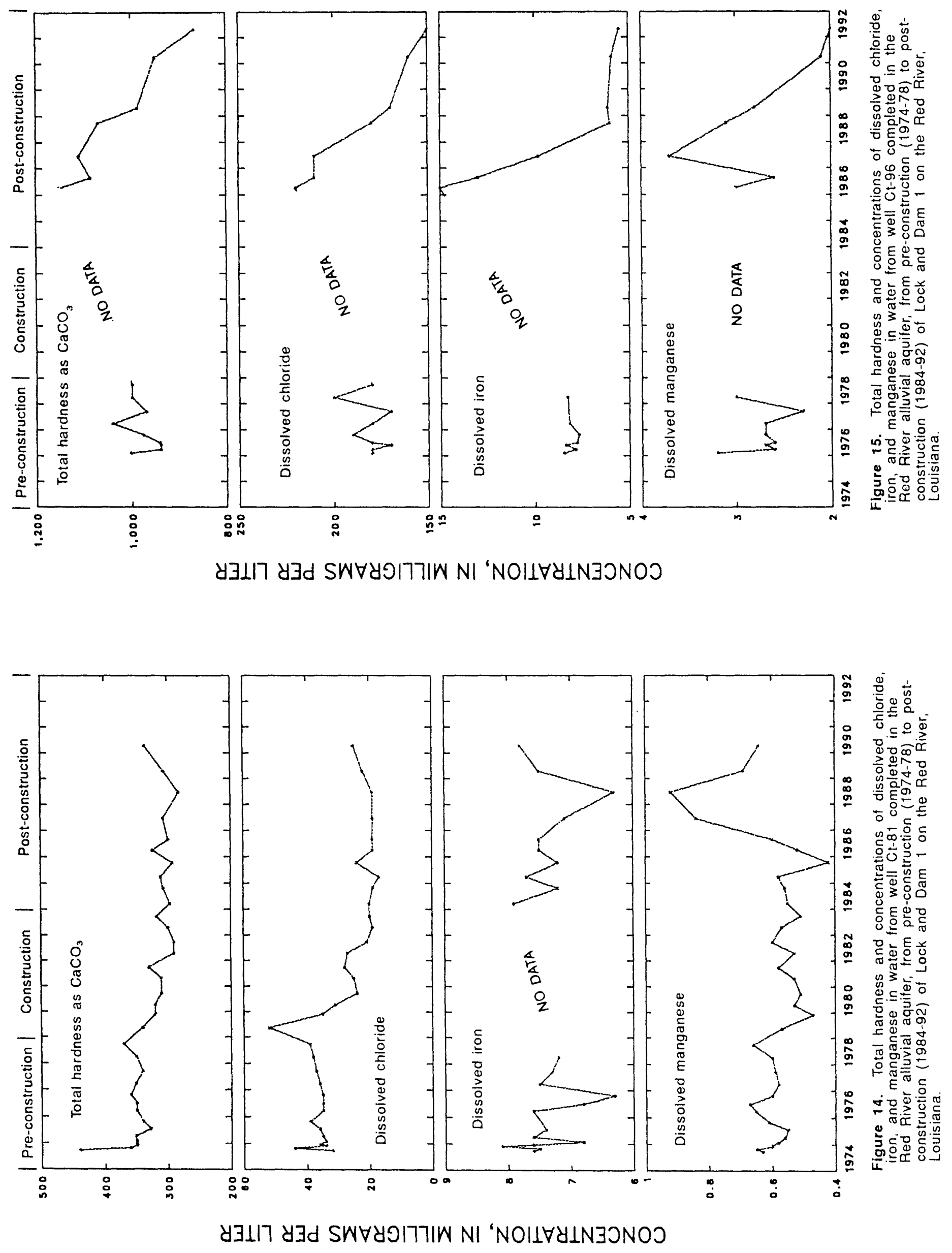

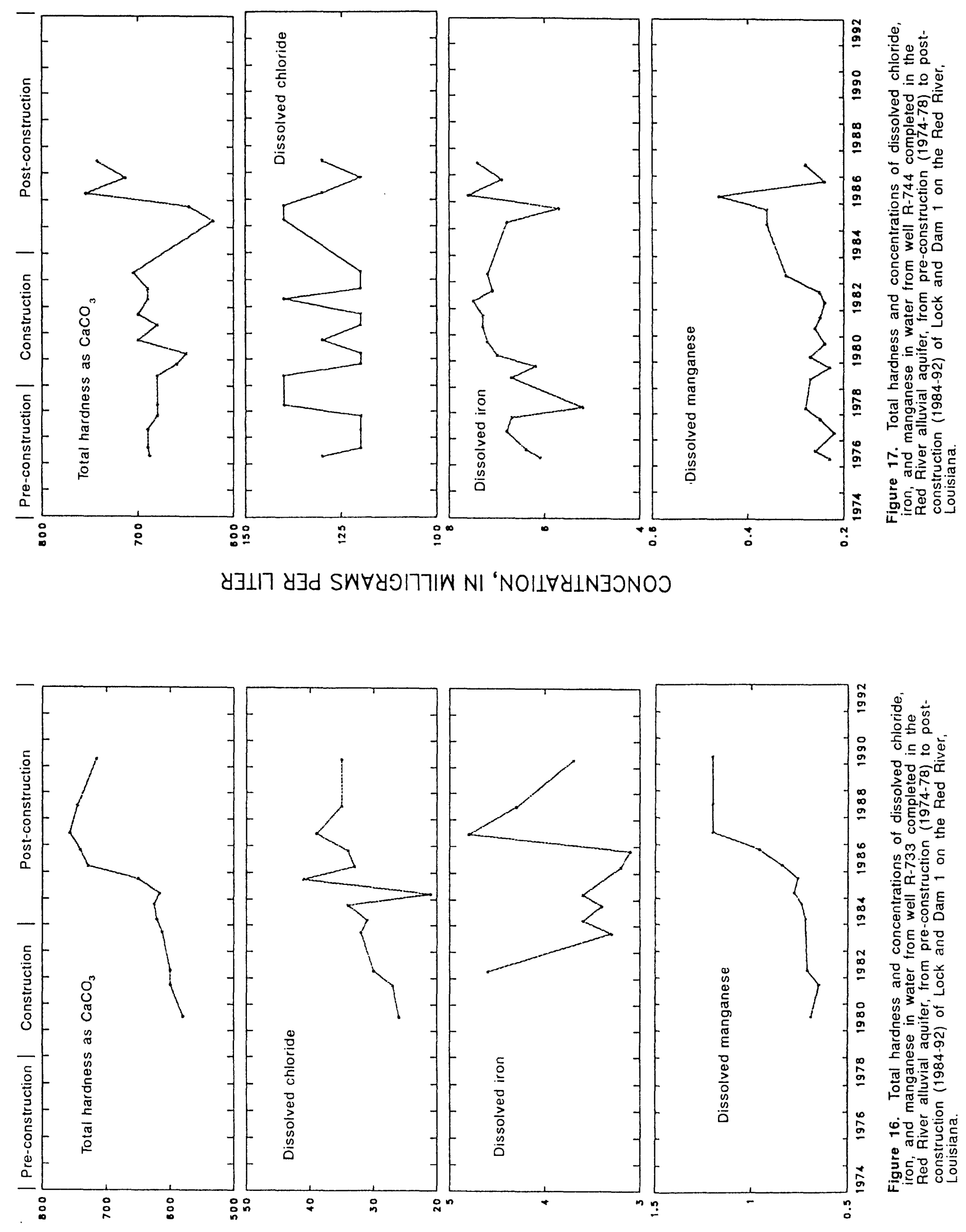

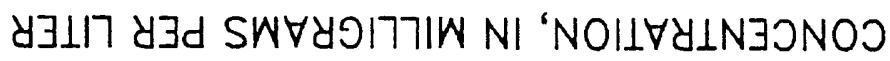




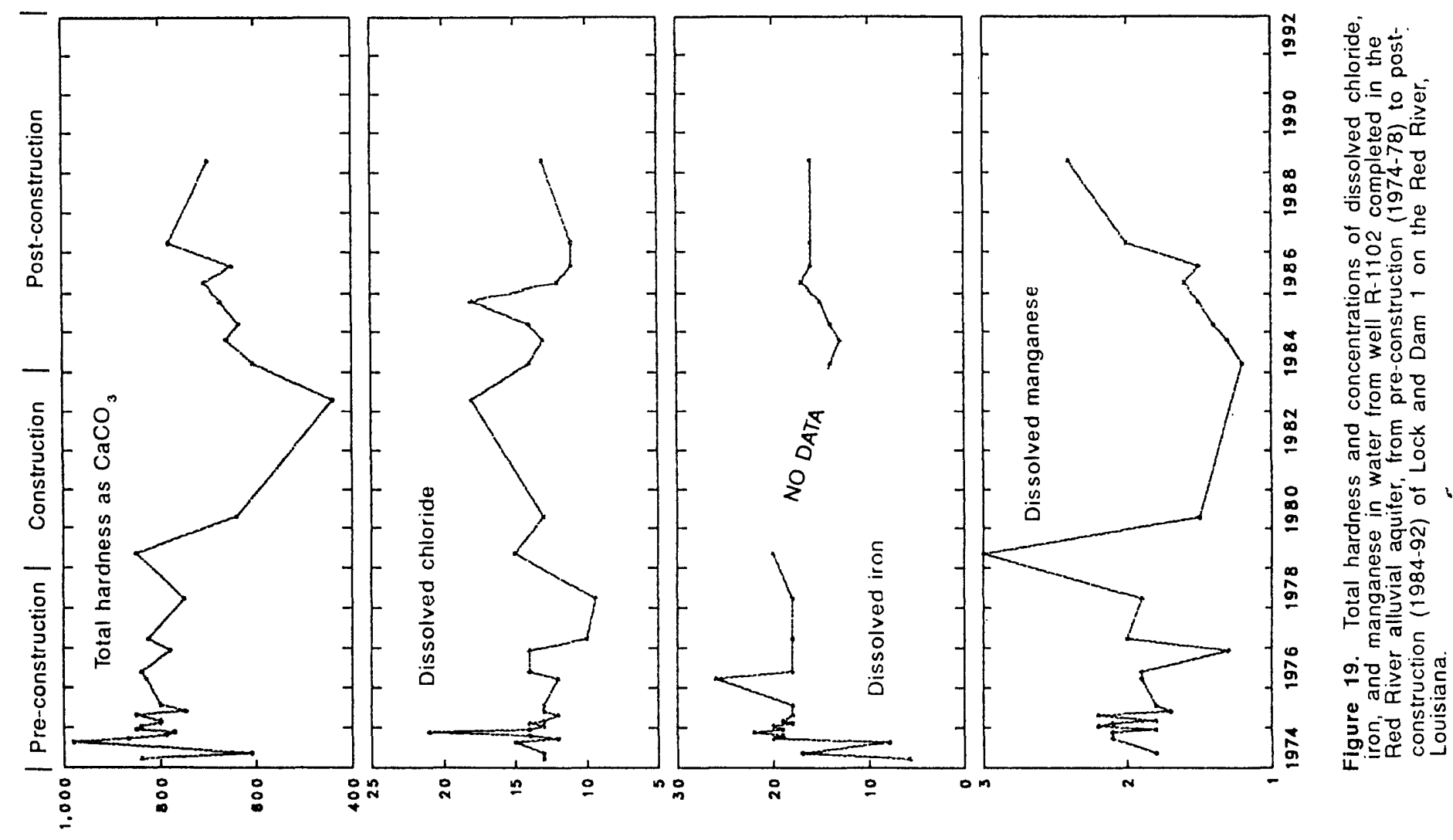

y3117 yבd SW
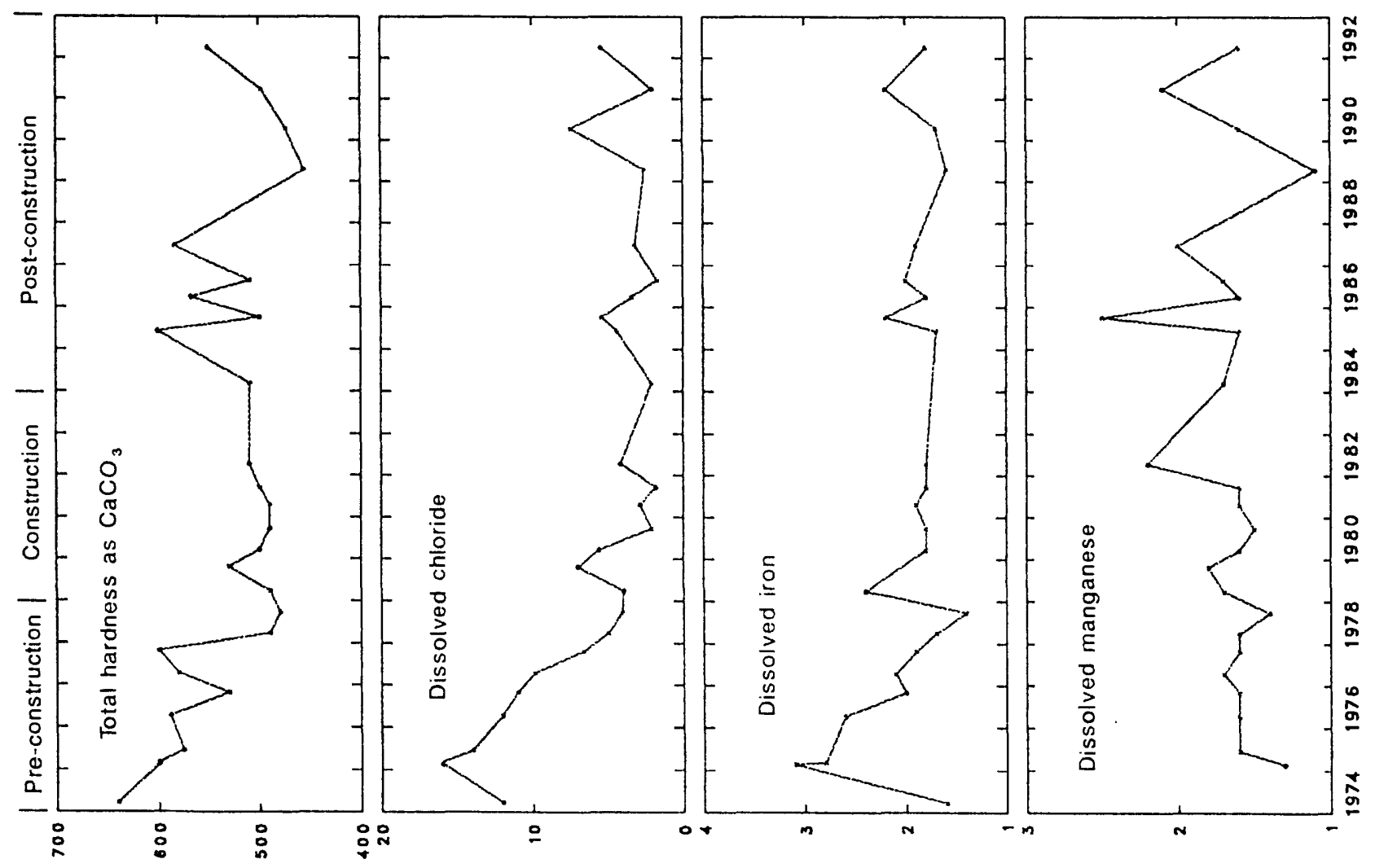

은

U. $\subseteq 9 \stackrel{0}{ \pm}$

कृष्ठ

年定

등요요

당

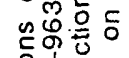

$\because$

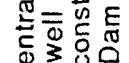

동흥등

을

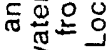

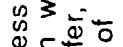

这完命

돌

으 옹를

है

車它离导

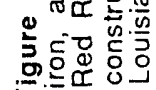


Table 2 lists well numbers, median values and concentrations, a range of values around the median value corresponding to the indicated confidence level, and the number of data points contained in the data sets for total hardness and dissolved chloride, iron, and manganese during preconstruction and post-construction sampling periods for most wells shown in figure 1. Because of insufficient data points, table 2 does not include wells Av-331, Av-339, R-733, and R-744. The target confidence level for calculated ranges around the median value in table 2 was 95 percent. Variability in the confidence level is inherent in the use of median rather than mean values. The technique used in calculating ranges around median values and in establishing the exact corresponding confidence levels listed in table 3 is discussed in greater detail by Iman and Conover (1983, p. 198-202).

The procedure used to establish documentable changes (an increase or decrease as shown in table 3) between pre-construction and post-construction sampling periods uses the calculated range of values around the median value shown in table 2 . If the calculated ranges around the median values of pre-construction and post-construction sampling periods overlap, then no documentable difference exists between pre-construction and post-construction sampling periods. If the calculated ranges around the median values of pre-construction and post-construction sampling periods do not overlap and the median value of the post-construction sampling period is greater than the median value of the pre-construction sampling period then an increase (+ value in table 3 ) has occurred. If the calculated ranges around the median values of pre-construction and post-construction sampling periods do not overlap and the median value of the post-construction sampling period is less than the median value of the pre-construction sampling period then a decrease (- value in table 3 ) has occurred. In instances where a change has occurred between pre-construction and post-construction sampling periods, the magnitude of the change can be approximated by subtracting the pre-construction sampling period median value from the post-construction sampling period median value. This approach to statistical analysis of data is not applicable to data sets that show temporal trends. Data sets showing change between pre-construction and post-construction sampling periods and showing temporal trends in either pre-construction or post-construction sampling periods will be discussed on an individual basis.

The results of statistical analysis of total hardness and dissolved chloride, iron, and manganese data collected during pre-construction and post-construction sampling periods for wells shown in figure 1 are summarized in table 3 . Table 3 lists 8 increases between pre-construction and postconstruction sampling periods, 15 decreases between pre-construction and post-construction sampling periods, 27 instances of no documentable difference between pre-construction and postconstruction sampling periods, and 18 instances of insufficient data on which to base a decision.

\section{Total Hardness}

Analyses of water from wells Av-381 (fig. 10) and Ct-74 (fig. 12) indicated increases and water from wells Av-153 (fig. 2), Av-370 (fig. 7), Av-371 (fig. 8), Av-372A (fig. 9), Av-382 (fig. 11), and Ct-81 (fig. 14) indicated decreases in the median hardness between pre-construction and postconstruction sampling periods (table 3 ). Wells containing water that indicated a change and a no detectable difference in median hardness between pre-construction and post-construction sampling periods are shown in figure 20.

Analysis of water from well Ct-74 indicated an increasing temporal trend in hardness during the pre-construction and post-construction sampling periods. The trend began about 1976, continued into 1987, and became essentially constant through 1992. Wells Av-370 and Av-372A indicated a decreasing temporal trend in hardness during pre-construction and post-construction sampling periods. The trend began in about 1976 for well Av-372A and continued into 1992. The trend for 


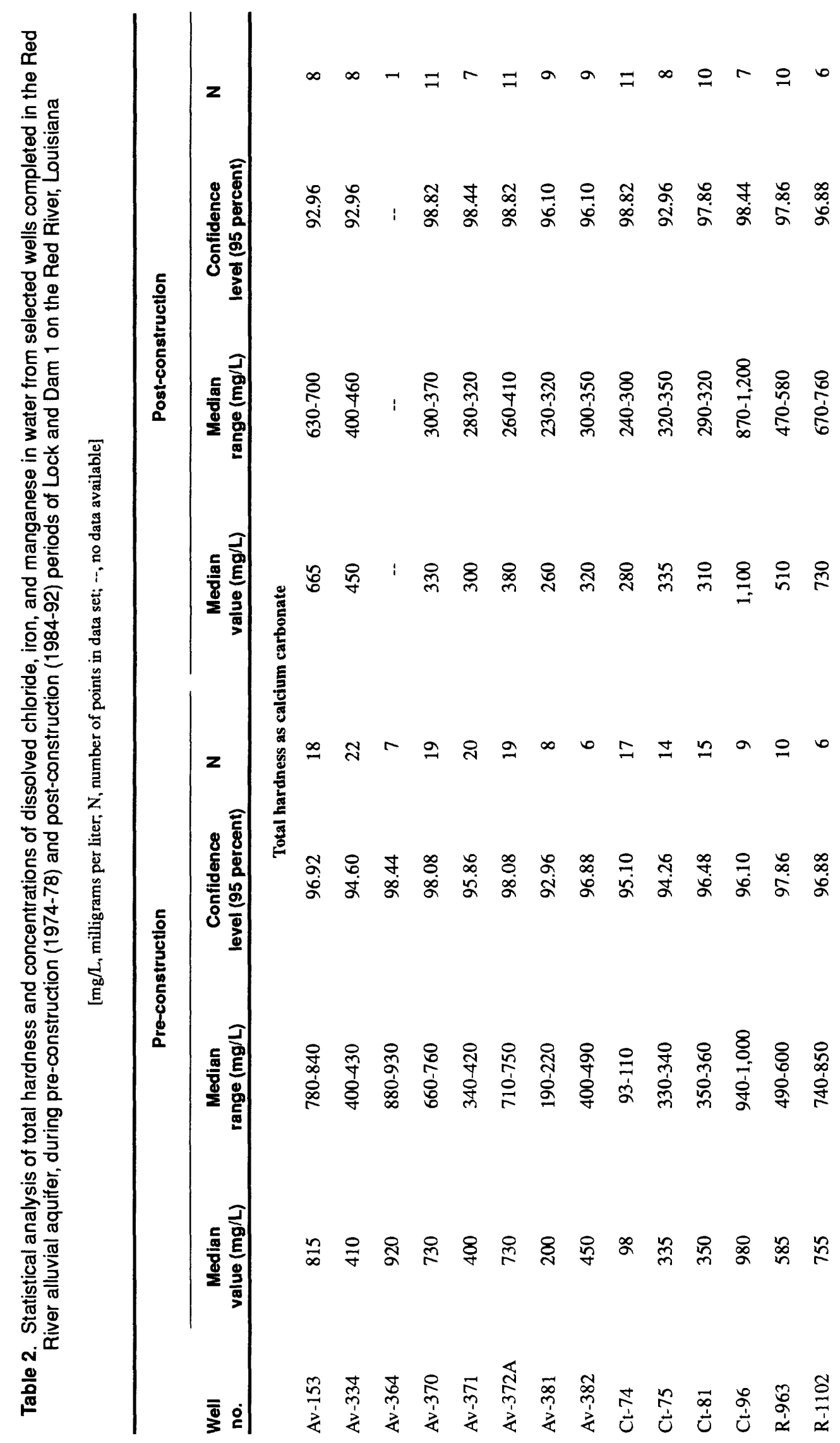




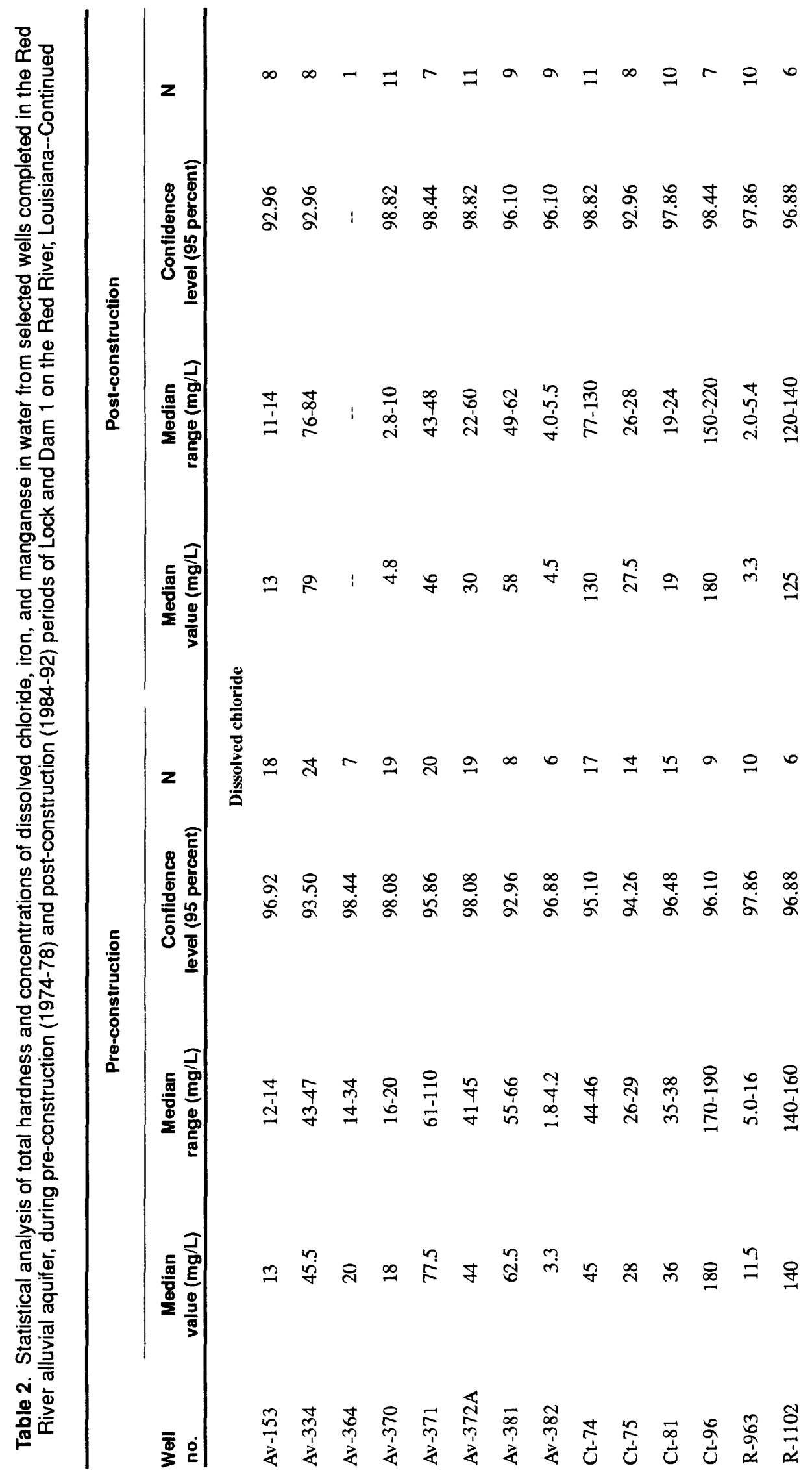




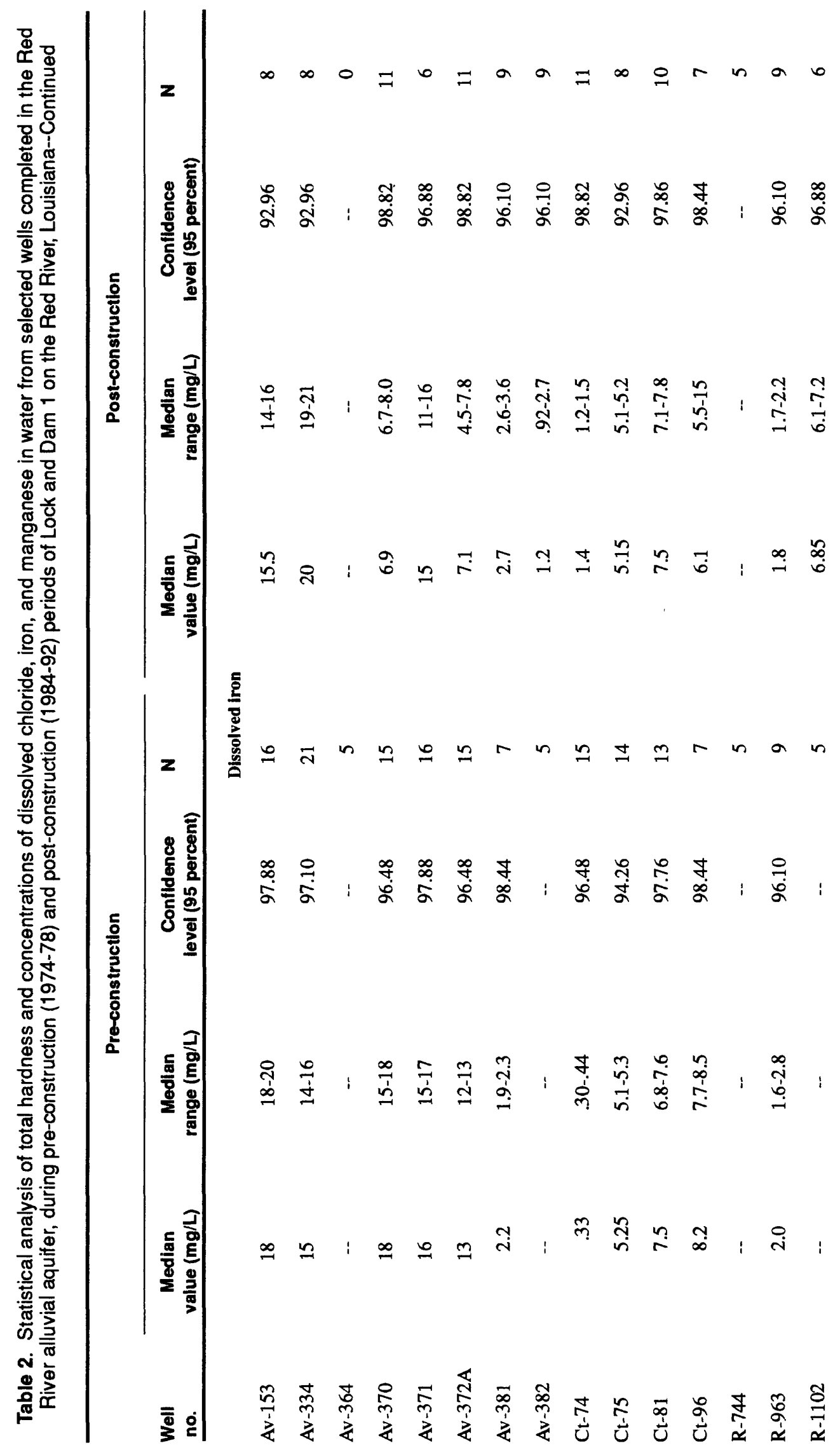




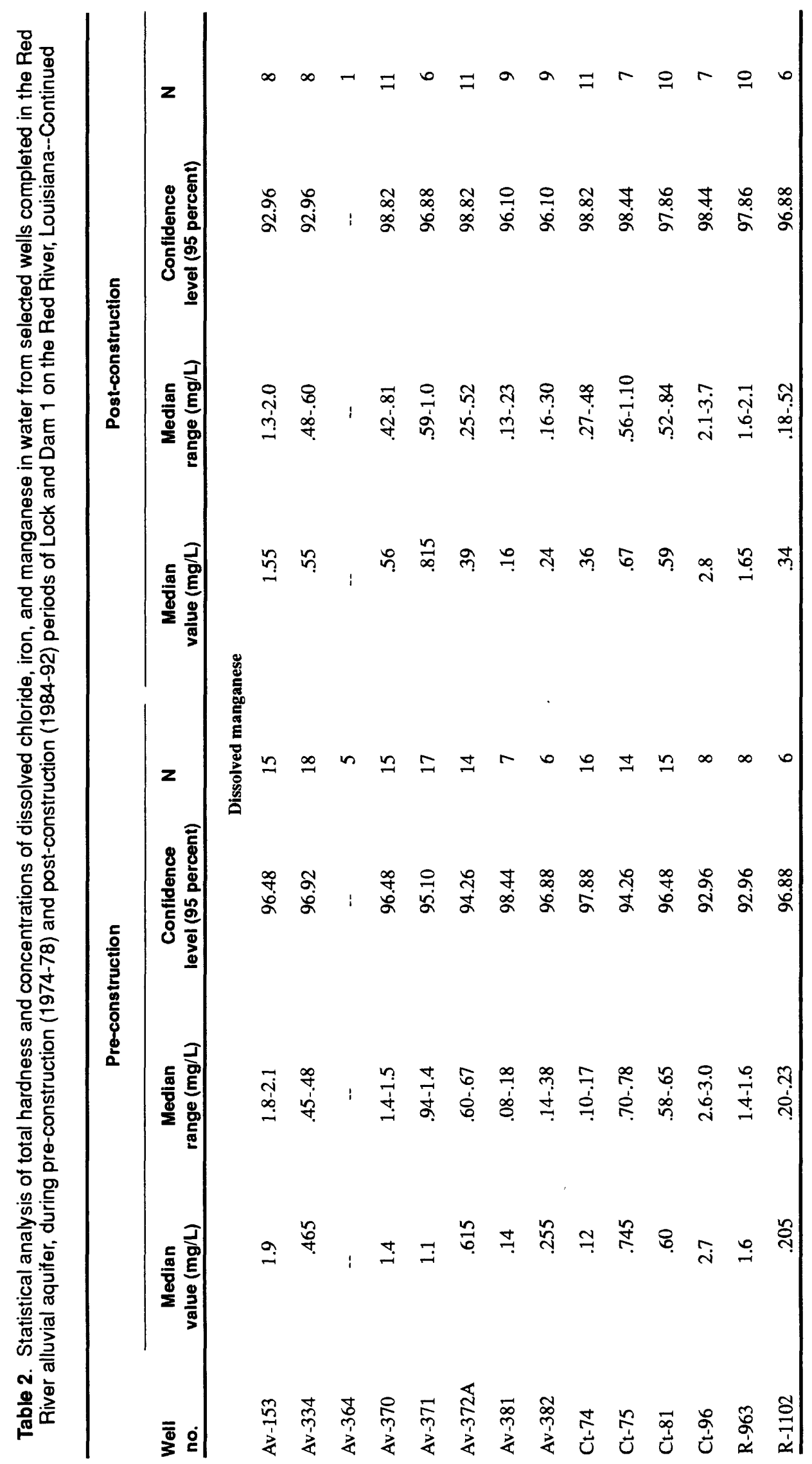




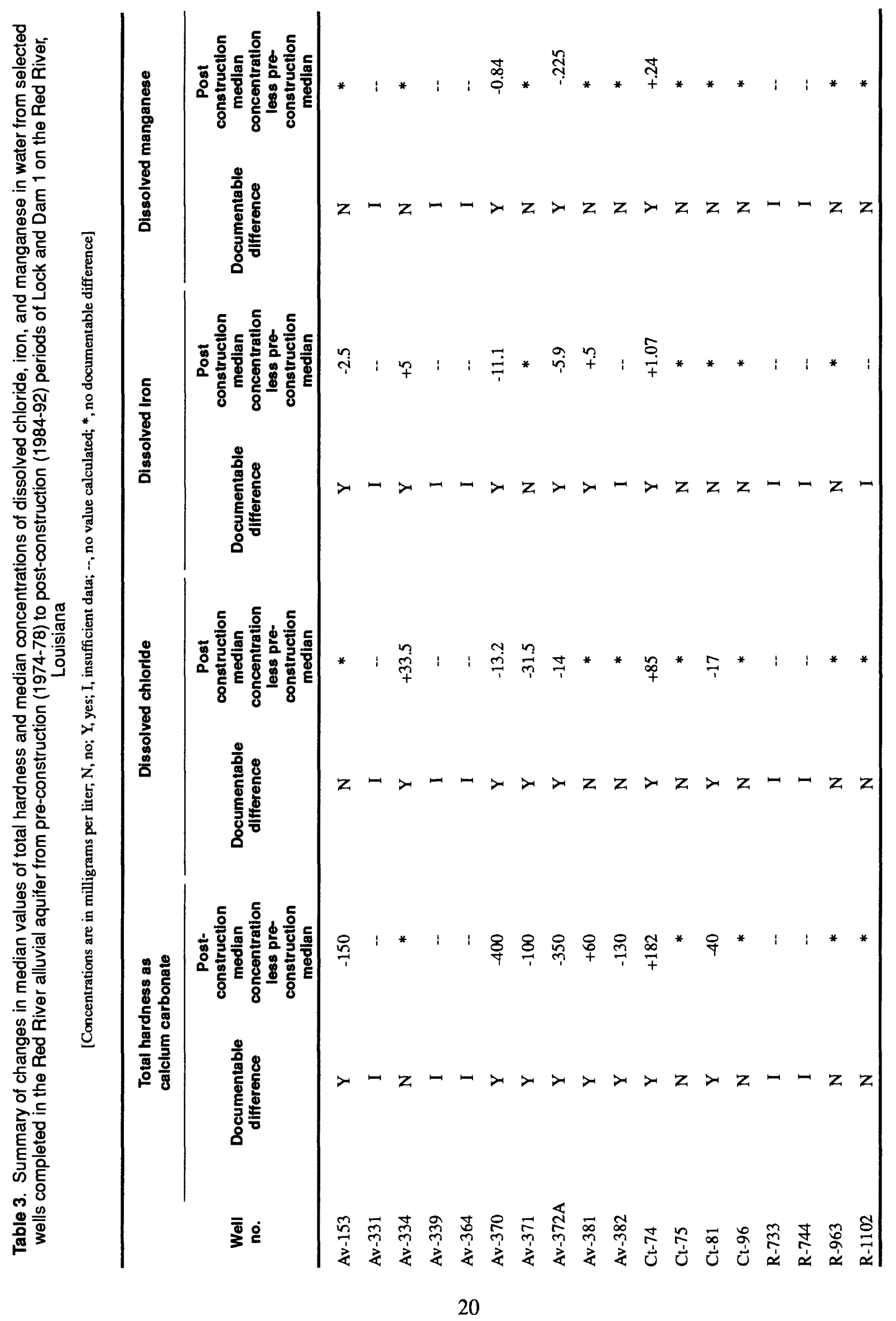




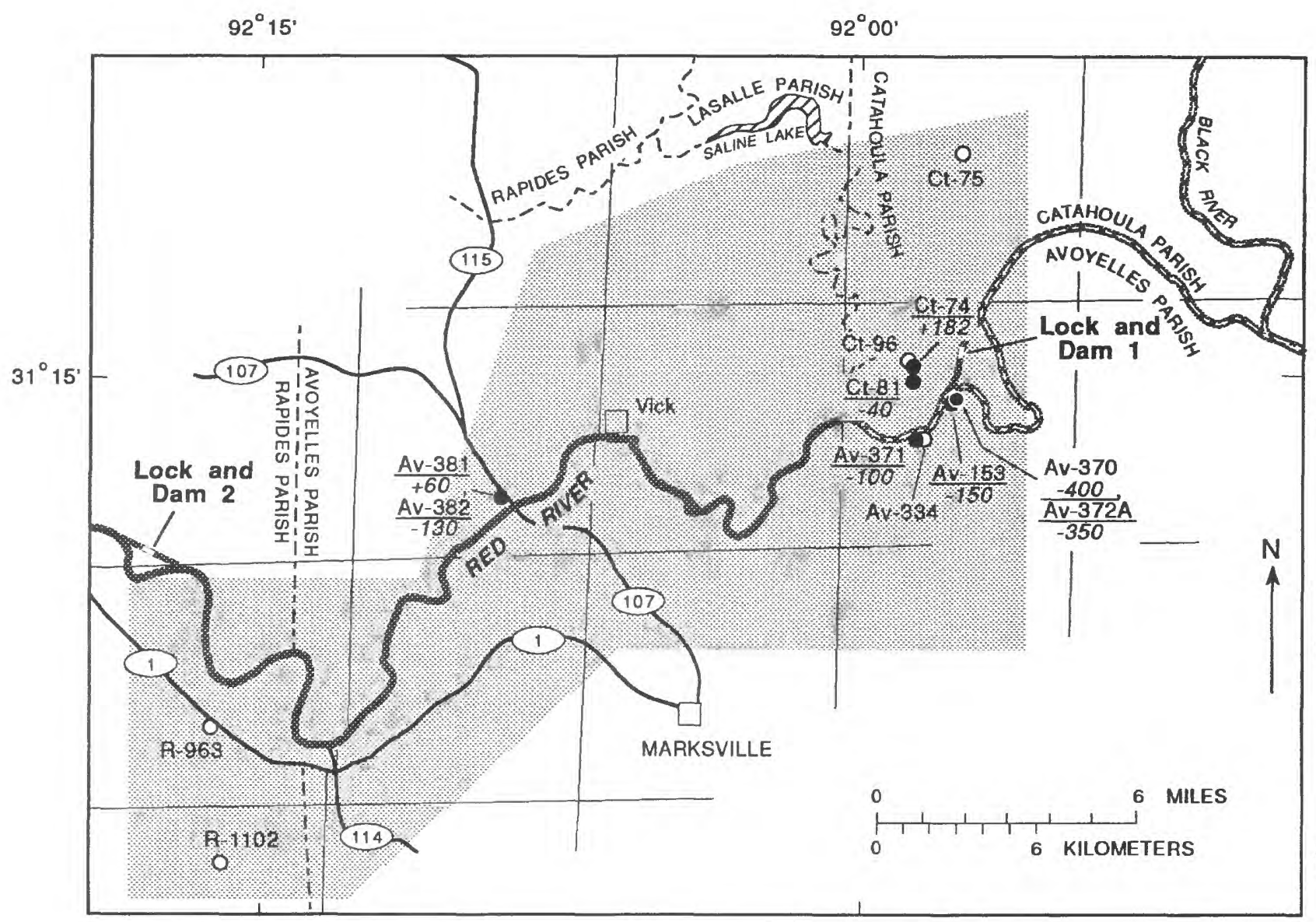

T. $4 \mathrm{~N}$.

T. $3 \mathrm{~N}$.

R. $2 \mathrm{E}$.

R. $3 E$.

R. $4 \mathrm{E}$.

R. $5 \mathrm{E}$.

R. $6 \mathrm{E}$.

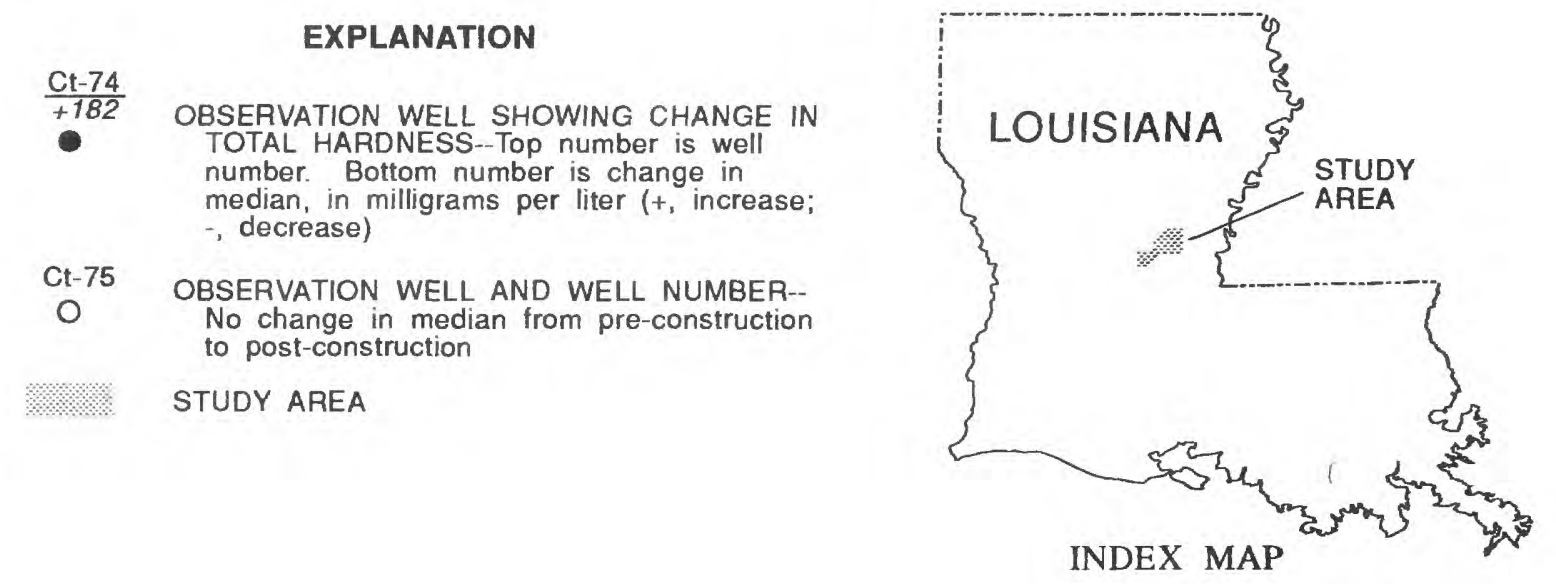

Figure 20. Changes in median values of total hardness of water from wells completed in the Red River alluvial aquifer, from pre-construction (1974-78) to post-construction (1984-92) of Lock and Dam 1 on the Red River, Louisiana. 
well Av-370 continued into 1991, but in 1992 the hardness had increased to almost the preconstruction level. Well Av-382 indicated a decreasing temporal trend in hardness during the preconstruction sampling period; the trend began in about 1976 and continued into 1978. The presence of temporal trends in pre-construction and post-construction sampling periods for hardness indicates that hydrologic factors other than the construction of Lock and Dam 1 have affected hardness in wells Ct-74, Av-372A, and Av-382.

Excluding wells Ct-74, Av-372A, and Av-382, data for four wells south of Lock and Dam 1 indicated decreases in hardness between pre-construction and post-construction sampling periods. Data for well Av-381, located about 10 mi west and about 2.5 mi south of Lock and Dam 1, indicated an increase in hardness between pre-construction and post-construction periods.

\section{Dissolved Chloride}

Analyses of water from wells Av-334 (fig. 4) and Ct-74 (fig. 12) indicated increases and water from wells Av-370 (fig. 7), Av-371 (fig. 8), Av-372A (fig. 9), and Ct-81 (fig. 14) indicated decreases in the median concentration of dissolved chloride between pre-construction and post-construction sampling periods. Wells containing water that indicated a change and a no detectable difference in the median concentration of dissolved chloride between pre-construction and post-construction sampling periods are shown in figure 21.

Analysis of water from well Av-372A indicated a decreasing temporal trend in the concentration of dissolved chloride during the pre-construction and post-construction sampling periods. The trend began about 1976 and continued into 1987, but indicated an increasing trend from 1989 to 1992 . The presence of a temporal trend during pre-construction and post-construction sampling periods for chloride indicates that hydrologic factors other than the construction of Lock and Dam 1 have affected the concentration of dissolved chloride in well Av-372A.

Only wells within about $2 \mathrm{mi}$ of Lock and Dam 1 indicated changes in the concentration of dissolved chloride between pre-construction and post-construction sampling periods. One well to the north of Lock and Dam 1 indicated an increase in the concentration of dissolved chloride between pre-construction and post-construction sampling periods. Excluding well Av-372A, three wells south of Lock and Dam 1 indicated decreases and one well south of Lock and Dam 1 indicated an increase in the concentration of dissolved chloride between pre-construction and post-construction sampling periods. Some of the increases in dissolved chloride concentrations probably are due to upconing of saltwater from underlying sands of Tertiary age caused by the water level in the alluvial aquifer being lowered about $40 \mathrm{ft}$ (table 1) due to dewatering of wells during the construction of Lock and Dam 1.

\section{Dissolved Iron}

Median concentrations of dissolved iron in water from wells Av-334 (fig. 4), Av-381 (fig. 10), and Ct-74 (fig. 12) indicated increases and wells Av-153 (fig. 2) and Av-372A (fig. 9) indicated decreases between analyses for pre-construction and post-construction sampling periods. Wells containing water that indicated a change and a no detectable difference in the median concentration of dissolved iron between pre-construction and post-construction sampling periods are shown in figure 22. 


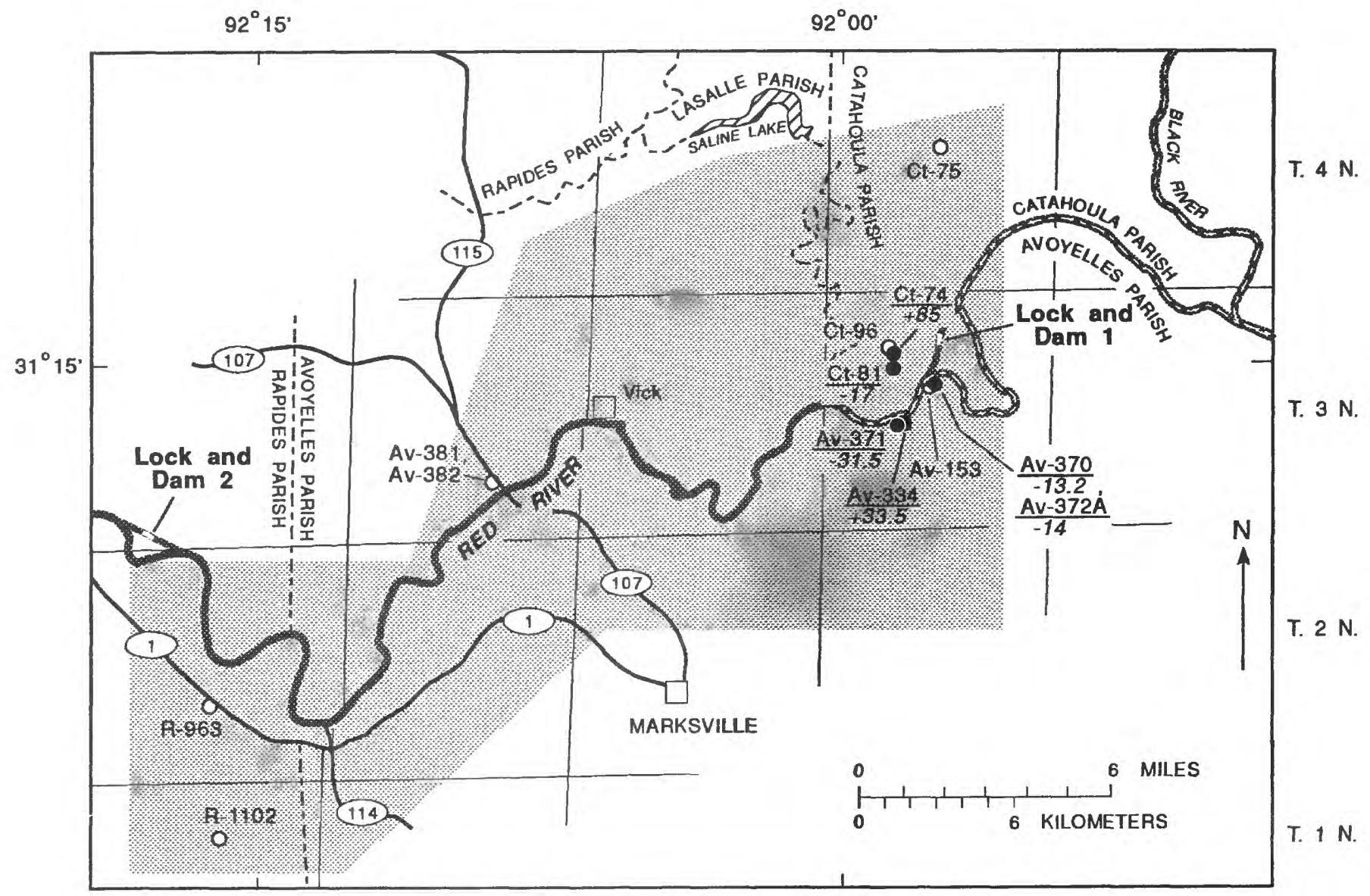
R. $2 \mathrm{E}$.
R. $3 \mathrm{E}$.
R. $4 \mathrm{E}$.
R. $5 \mathrm{E}$.
R. $6 \mathrm{E}$.

\section{EXPLANATION}

$\frac{\mathrm{Ct}-74}{+85}$ OBSERVATION WELL SHOWING CHANGE IN DISSOLVED CHLORIDE--Top number is well number. Bottom number is change in median, in milligrams per liter $(t$, increase; - , decrease)

Ct-75 OBSERVATION WELL AND WELL NUMBER-No change in median from pre-construction to post-construction

STUDY AREA

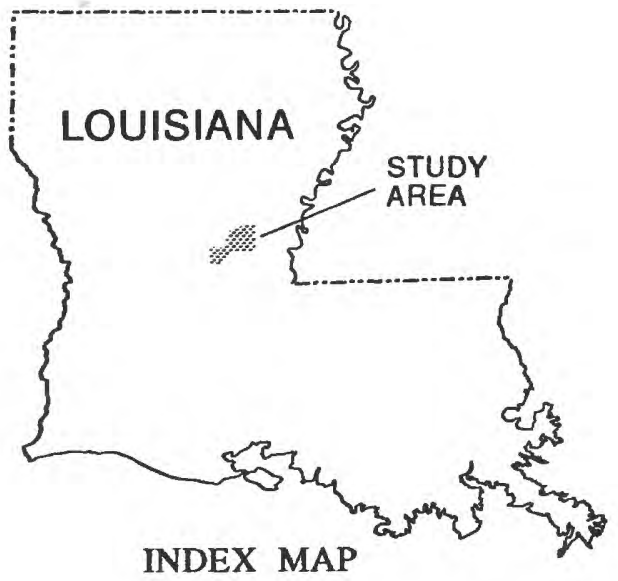

Figure 21. Changes in median concentration of dissolved chloride in water from wells completed in the Red River alluvial aquifer, from pre-construction (1974-78) to post-construction (1984-92) of Lock and Dam 1 on the Red River, Louisiana. 


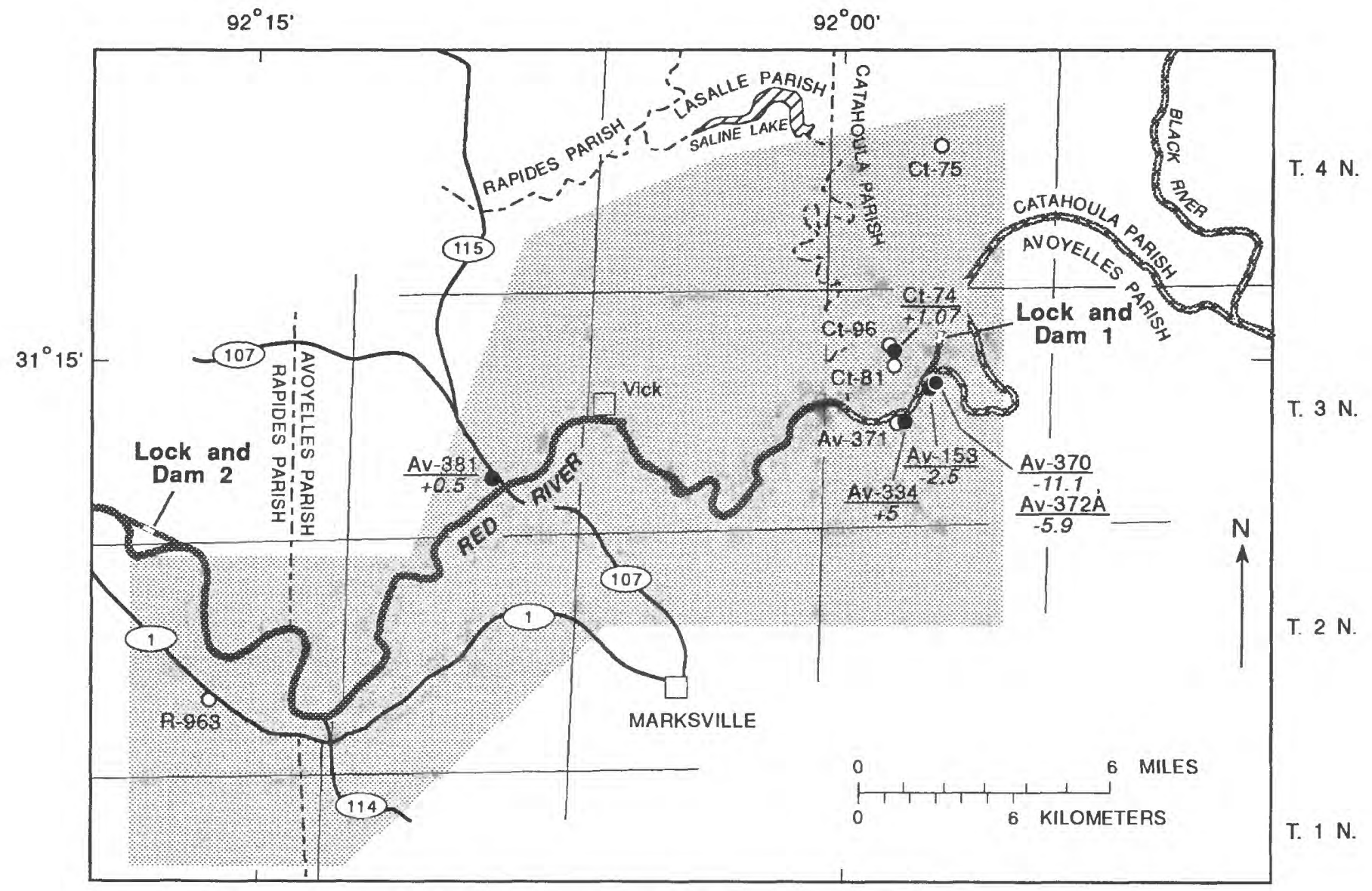

R. $2 \mathrm{E}$.

R. $3 E$.

R. $4 \mathrm{E}$

R. $5 \mathrm{E}$.

R. $6 \mathrm{E}$.

\section{EXPLANATION}
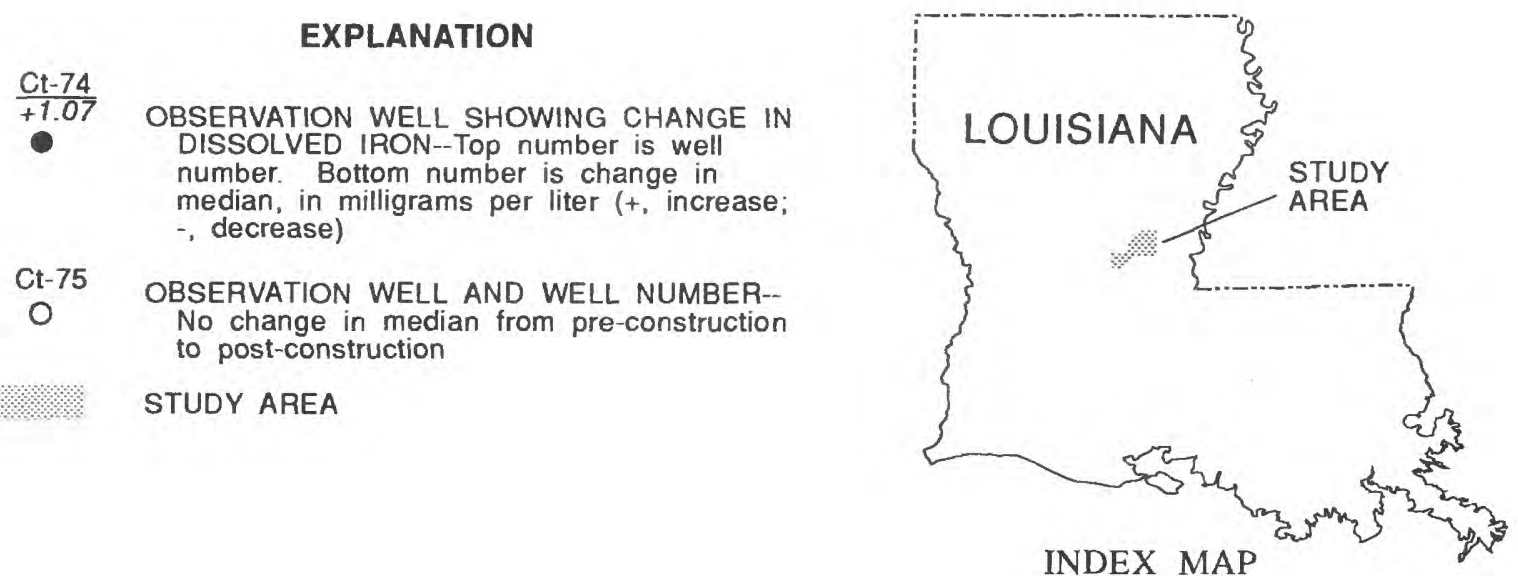

Figure 22. Changes in median concentration of dissolved iron in water from wells completed in the Red River alluvial aquifer, from pre-construction (1974-78) to post-construction (1984-92) of Lock and Dam 1 on the Red River, Louisiana. 
Water analyses for well Av-370 (fig. 7) indicated a decrease in the concentration of dissolved iron between pre-construction and post-construction. However, the iron concentration increased, from a low in 1989, to a level in 1992 comparable with the pre-construction level. Data for well Av381 indicated considerable variation in the concentration of dissolved iron during the postconstruction sampling period. While there is an apparent increase in the post-construction concentrations of dissolved iron from the pre-construction concentrations of dissolved iron, particularly in samples collected in 1988 and 1990, the differences in median concentrations between pre-construction and post-construction sampling periods should be interpreted with caution. Data for well $\mathrm{Ct}-74$ indicated an increasing temporal trend in the concentration of dissolved iron during the pre-construction and post-construction sampling periods, which began about 1977, continued into 1989 , and became essentially constant through 1992 . The presence of a temporal trend in preconstruction and post-construction sampling periods for iron indicates that hydrologic factors other than the construction of Lock and Dam 1 have affected the concentration of dissolved iron in well Ct74.

Excluding well Ct-74, data for three wells within approximately 1 mi south of Lock and Dam 1 indicated decreases, and data for one well about $3 \mathrm{mi}$ south of Lock and Dam 1 indicated an increase in the concentration of dissolved iron between pre-construction and post-construction sampling periods. Data for one additional well about $10 \mathrm{mi}$ west and about $2.5 \mathrm{mi}$ south of Lock and Dam 1 indicated an increase in the concentration of dissolved iron between pre-construction and postconstruction periods.

\section{Dissolved Manganese}

Median concentrations of dissolved manganese in water from well Ct-74 (fig. 12) indicated an increase and wells Av-370 (fig. 7), and Av-372A (fig. 9) indicated a decrease between preconstruction and post-construction sampling periods. Wells containing water that indicated a change in the median concentration of dissolved manganese between pre-construction and post-construction sampling periods are shown in figure 23 .

Data for well Ct-74 indicated an increasing temporal trend in the concentration of dissolved manganese during pre-construction and post-construction sampling periods beginning in about 1975 and continuing at least into about 1988, followed by a usually constant concentration through 1992. The presence of a temporal trend in pre-construction and post-construction sampling periods indicates that hydrologic factors other than the construction of Lock and Dam 1 have affected the concentration of dissolved manganese in well Ct-74.

Only wells within approximately $1 \mathrm{mi}$ of Lock and Dam 1 indicated changes in the concentration of dissolved manganese between pre-construction and post-construction sampling periods. Excluding well Ct-74, data for two wells to the south of Lock and Dam 1 indicated decreases in the concentration of dissolved manganese between pre-construction and post-construction sampling periods. 


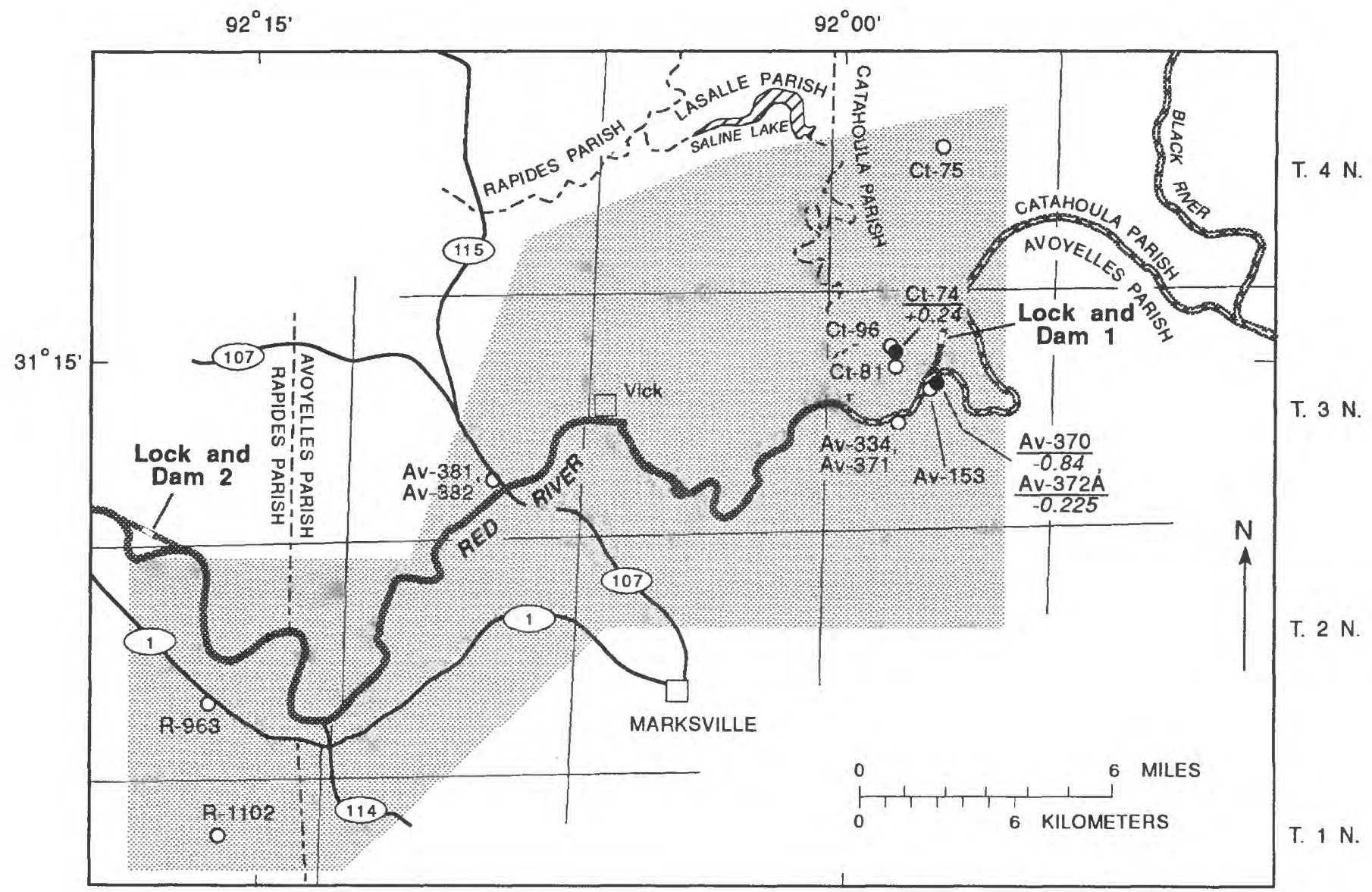
R. $2 \mathrm{E}$.
R. $3 \mathrm{E}$.
R. $4 \mathrm{E}$.
R. $5 \mathrm{E}$.
R. $6 \mathrm{E}$.

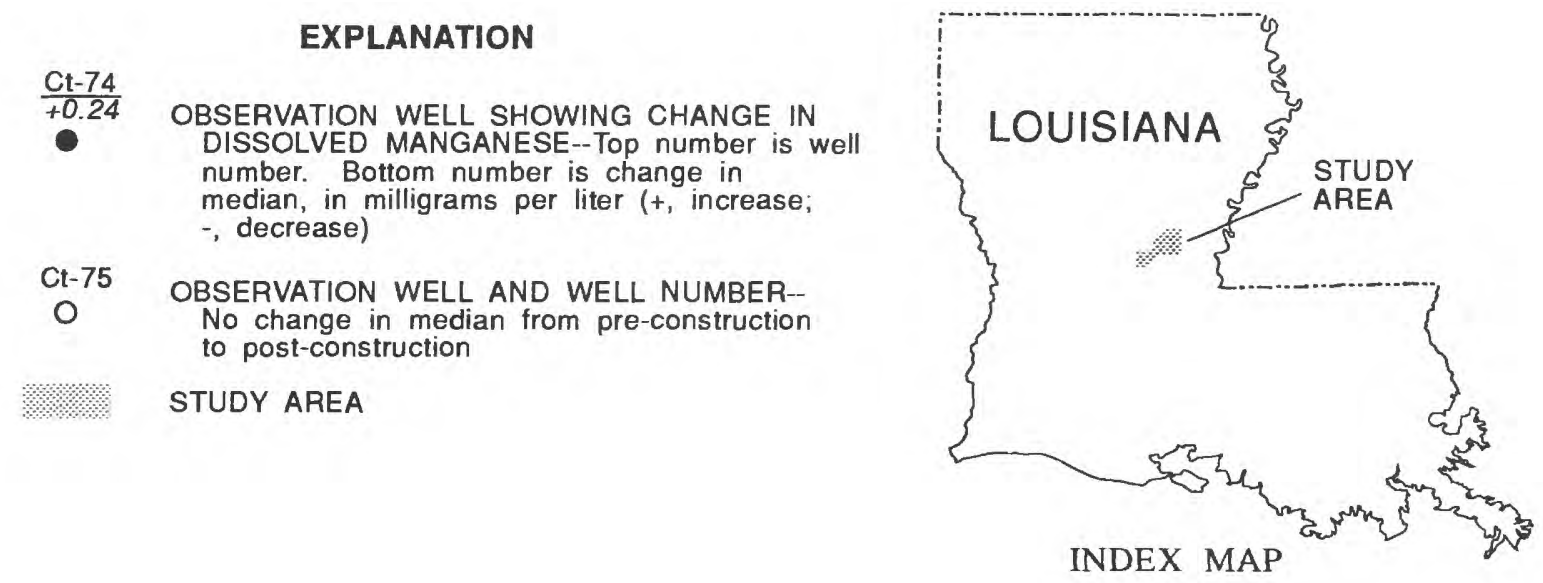

Figure 23. Changes in median concentration of dissolved manganese in water from wells completed in the Red River alluvial aquifer, from pre-construction (1974-78) to post-construction (1984-92) of Lock and Dam 1 on the Red River, Louisiana. 


\section{SUMMARY AND CONCLUSIONS}

The quality of water in the Red River alluvial aquifer was monitored during pre-construction (1974-78), construction (1980-83), and post-construction (1984-92) of Lock and Dam 1, to document background conditions and establish a data base for future evaluation of the effects of construction and operation of the structures on the aquifer. Fifteen wells completed in the Red River alluvial aquifer within the study area have been sampled periodically from 1974 to 1990; five of these wells also were sampled in 1991 and 1992. Intermittent samples were collected from three other wells completed in the Red River alluvial aquifer in the study area. Total hardness as calcium carbonate and dissolved chloride, iron, and manganese concentrations, calculated from data collected during these sampling periods, were used to determine changes in quality of water in the aquifer, between pre-construction and post-construction of Lock and Dam 1.

Changes in median values and concentrations that were unaffected by temporal trends in total hardness and concentrations of dissolved chloride, iron, and manganese between the pre-construction and post-construction sampling periods were confined to within approximately 2 miles of Lock and Dam 1, except for increases in total hardness and dissolved iron concentration in well Av-381. Generally, total hardness and concentrations of dissolved chloride, iron, and manganese in the alluvial aquifer south of Lock and Dam 1 decreased between the pre-construction and postconstruction sampling periods when changes, unaffected by temporal trends, occurred. Exceptions to this generalization were increases in the concentrations of dissolved chloride and iron in well Av-334 between the pre-construction and post-construction sampling periods. Change, unaffected by temporal trends, north of Lock and Dam 1 was limited to an increase in the concentration of dissolved chloride in well $\mathrm{Ct}-74$ between the pre-construction and post-construction sampling periods. Because well Ct-74 is completed in a sand that is in contact with a saltwater sand of Tertiary age, this increase is probably a temporal increase due to upconing after lowering the water level in the alluvial aquifer by pumping of dewatering wells during construction of Lock and Dam 1.

The temporal trends during the pre-construction and post-construction sampling periods for total hardness and dissolved chloride and iron indicate that hydrologic factors other than the construction of Lock and Dam 1 have affected the quality of water in some of the wells completed in the Red River alluvial aquifer.

\section{SELECTED REFERENCES}

American Public Health Association, American Water Works Association, and Water Pollution Control Federation, 1980, Standard methods for the examination of water and wastewater (15th ed.): New York, American Public Health Association, Inc., 1134 p.

Brown, Eugene, Skougstad, M.W., and Fishman, M.J., 1970, Methods for collection and analysis of water samples for dissolved minerals and gases: U.S. Geological Survey Techniques for Water-Resources Investigations, book 5, chap. A1, $160 \mathrm{p}$.

Fishman, M.J., and Friedman, L.C., eds., 1989, Methods for determination of inorganic substances in water and fluvial sediments: U.S. Geological Survey Techniques of Water-Resources Investigations Report, book 5, chap. A1, 545 p.

Iman, R.L., and Conover, W.J., 1983, A Modern Approach to Statistics: New York, John Wiley and Sons, $497 \mathrm{p}$.

Ludwig, A.H., 1974, Quality of water in the Red River alluvial aquifer, Shreveport to the mouth of the Black River, Louisiana: U.S. Geological Survey Open-File Report, 7 p. 
Rogers, J.E., 1988, Red River Waterway Project--Summary of ground-water studies by the U.S. Geological Survey, 1962-85: U.S. Geological Survey Water-Resources Investigations Report 87-4261, $19 \mathrm{p}$.

Smoot, C.W., 1983, Records of water-level measurements and lithologic logs, Red River Valley, Louisiana, 1975-80: Louisiana Department of Transportation and Development, Office of Public Works Water Resources Basic Records Report no. 12, 197 p.

Smoot, C.W., and Guillot, J.R., 1988, Water-level measurements 1981-85 and chemical analyses 1978-85, Red River alluvial aquifer, Red River Valley, Louisiana: U.S. Geological Survey Open-File Report 87-541, 261 p.

Smoot, C.W., and Martin, Angel, Jr., 1991, Generalized potentiometric surfaces of the Red River alluvial aquifer, pool 1, Red River waterway area, central Louisiana: U.S. Geological Survey Water-Resources Investigations Report 91-4109, 7 map sheets.

Whitfield, M.S., Jr., 1980, Chemical character of water in the Red River alluvial aquifer, Louisiana: U.S. Geological Survey Water-Resources Investigations Open-File Report 80-1018, 95 p.

Wood, W.W., 1976, Guidelines for collection and field analysis of ground-water samples for selected unstable constituents: U.S. Geological Survey Techniques of Water-Resources Investigations, book 1, chap. D2, 24 p. 
TABLE 1 
Table 1. Summary of chemical and physical analyses of water from wells completed in the Red River alluvial aquifer, Louisiana, 1965-92

[ft, feet; $\mu \mathrm{S} / \mathrm{cm}$, microsiemens per centimeter at 25 degrees Celsius; ${ }^{\circ} \mathrm{C}$, degrees Celsius; $\mathrm{mg} / \mathrm{L}$, milligrams per liter; + , water level above land surface; $<$, actual value is known to be less than value shown; dashes indicate no data]

\begin{tabular}{|c|c|c|c|c|c|c|c|c|c|c|c|c|c|}
\hline $\begin{array}{c}\text { Well } \\
\text { no. }\end{array}$ & Date & $\begin{array}{l}\text { Water } \\
\text { level } \\
\text { below } \\
\text { land } \\
\text { sur- } \\
\text { face } \\
\text { (ft) }\end{array}$ & $\begin{array}{l}\text { Dept h } \\
\text { of } \\
\text { well, } \\
\text { total } \\
\text { (ft) }\end{array}$ & $\begin{array}{l}\text { Spe- } \\
\text { cific } \\
\text { con- } \\
\text { duct- } \\
\text { ance } \\
(\mu s / c m)\end{array}$ & $\begin{array}{l}\text { pH, } \\
\text { field } \\
\text { (stand- } \\
\text { ard } \\
\text { units) }\end{array}$ & $\begin{array}{l}\text { Temper- } \\
\text { ature of } \\
\text { water } \\
\left({ }^{\circ} \mathrm{C}\right)\end{array}$ & $\begin{array}{l}\text { Color } \\
\text { (plat- } \\
\text { inum- } \\
\text { cobalt } \\
\text { units) }\end{array}$ & $\begin{array}{l}\text { Hard- } \\
\text { ness, } \\
\text { total } \\
\text { (mg/L } \\
\text { as } \\
\mathrm{CaCO}_{3} \text { ) }\end{array}$ & $\begin{array}{l}\text { Hard- } \\
\text { ness, } \\
\text { noncarb } \\
\text { whole } \\
\text { water } \\
\text { total } \\
\text { field } \\
(\mathrm{mg} / \mathrm{L} \text { as } \\
\left.\mathrm{CaCO}_{3}\right)\end{array}$ & $\begin{array}{c}\text { Calcium, } \\
\text { dis- } \\
\text { solved } \\
\text { (mg/L } \\
\text { as Ca) }\end{array}$ & $\begin{array}{l}\text { Magne- } \\
\text { sium, } \\
\text { dis- } \\
\text { solved } \\
\text { (mg/L } \\
\text { as Mg) }\end{array}$ & $\begin{array}{l}\text { Sodium, } \\
\text { dis- } \\
\text { solved } \\
\text { (mg/L } \\
\text { as } \mathrm{Na} \text { ) }\end{array}$ & $\begin{array}{l}\text { Potas- } \\
\text { sium, } \\
\text { dis- } \\
\text { solved } \\
\text { (mg/L } \\
\text { as K) }\end{array}$ \\
\hline \multirow[t]{30}{*}{ AV -153} & $03-15-65$ & -- & 59 & -- & -- & -- & -- & -- & -- & - & -- & -- & -- \\
\hline & $03-23-74$ & -- & 59 & 1,490 & 6.3 & -- & -- & 840 & -- & -- & -- & -- & -- \\
\hline & $05-14-74$ & -- & 59 & 1,240 & 7.2 & -- & 5 & 610 & 0 & 160 & 51 & 31 & 5.1 \\
\hline & $08-23-74$ & 7.29 & 59 & 1,500 & 6.4 & -- & -- & 980 & -- & -- & -- & -- & -- \\
\hline & $09-24-74$ & 16.09 & 59 & 1,500 & 6.7 & -- & 5 & 870 & 10 & 240 & 65 & 17 & 5.7 \\
\hline & $10-21-74$ & 19.62 & 59 & 1,440 & 6.9 & -- & -- & 790 & -- & -- & -- & -- & -- \\
\hline & $11-18-74$ & 13.37 & 59 & 1,530 & 7.0 & -- & -- & 770 & -- & -- & -- & -- & -- \\
\hline & $12-16-74$ & 9.26 & 59 & 1,460 & 6.3 & 20.5 & -- & 850 & -- & -- & -- & -- & -- \\
\hline & $01-17-75$ & 7.06 & 59 & 1,460 & 6.7 & 21.0 & -- & 840 & -- & -- & -- & -- & -- \\
\hline & $02-11-75$ & 5.16 & 59 & 1,470 & 6.6 & -- & -- & 800 & -- & -- & -- & -- & -- \\
\hline & $03-05-75$ & 4.60 & 59 & 1,470 & 6.5 & 20.5 & -- & 800 & -- & -- & -- & -- & -- \\
\hline & $04-26-75$ & +3.62 & 59 & 1,430 & 6.4 & 21.0 & 5 & 850 & 0 & 230 & 67 & 27 & 4.4 \\
\hline & $06-03-75$ & 3.70 & 59 & 1,490 & 6.7 & -- & 0 & 750 & -- & 200 & 60 & 28 & 4.4 \\
\hline & $07-24-75$ & 17.32 & 59 & 1,500 & 6.2 & -- & -- & 800 & -- & -- & -- & -- & -- \\
\hline & $03-22-76$ & 14.52 & 59 & -- & 6.9 & -- & -- & 830 & -- & -- & -- & -- & -- \\
\hline & $05-27-76$ & 20.34 & 59 & -- & 7.0 & -- & -- & 840 & -- & -- & -- & -- & -- \\
\hline & $12-09-76$ & 28.99 & 59 & -- & -- & -- & -- & 780 & -- & -- & -- & -- & -- \\
\hline & $03-29-77$ & 19.75 & 59 & -- & 7.0 & -- & 0 & 830 & 0 & 230 & 61 & 28 & 5.4 \\
\hline & $03-27-78$ & 20.74 & 59 & -- & 6.7 & -- & -- & 750 & -- & -- & -- & -- & -- \\
\hline & $05-10-79$ & 21.97 & 59 & -- & 6.9 & -- & -- & 850 & -- & -- & - & -- & -- \\
\hline & $04-16-80$ & 31.89 & 59 & -- & -- & -- & -- & 640 & -- & -- & -- & -- & -- \\
\hline & $04-18-83$ & 29.89 & 59 & -- & -- & -- & -- & 440 & -- & -- & -- & -- & -- \\
\hline & $03-21-84$ & 18.80 & 59 & -- & 6.8 & -- & -- & 610 & -- & 150 & 56 & -- & -- \\
\hline & $10-24-84$ & 24.11 & 59 & -- & 6.9 & -- & -- & 660 & -- & -- & 61 & -- & -- \\
\hline & $03-14-85$ & 11.74 & 59 & -- & 6.8 & -- & -- & 630 & -- & 160 & 57 & -- & -- \\
\hline & $10-08-85$ & 26.30 & 59 & -- & 7.0 & -- & -- & 670 & -- & 170 & 60 & -- & -- \\
\hline & $04-01-86$ & 18.57 & 59 & -- & 6.8 & -- & -- & 700 & -- & 170 & 68 & -- & -- \\
\hline & $08-29-86$ & 23.44 & 59 & -- & 6.9 & 23.5 & -- & 650 & -- & 160 & 60 & -- & -- \\
\hline & $03-26-87$ & 8.26 & 59 & 1,300 & 6.9 & 20.0 & -- & 770 & -- & 200 & 68 & -- & -- \\
\hline & $04-19-89$ & 11.65 & 59 & 1,370 & 6.8 & 20.5 & 10 & 700 & -- & 170 & 66 & 27 & 4.5 \\
\hline \multirow[t]{7}{*}{$A V-331$} & $04-21-70$ & -- & 42 & 2,100 & 6.3 & -- & 1 & 790 & 690 & 250 & 41 & 160 & 1.1 \\
\hline & $04-08-74$ & -- & 42 & 1,540 & 5.7 & 20.5 & -- & 440 & -- & -- & -- & -- & -- \\
\hline & $07-22-75$ & -- & 42 & 1,430 & -- & 20.0 & 0 & 530 & 380 & 120 & 55 & 120 & .8 \\
\hline & $10-22-76$ & -- & 42 & - & 6.5 & -- & -- & 860 & -- & -- & -- & -- & -- \\
\hline & $09-19-88$ & 7.43 & 42 & 807 & 6.3 & 20.0 & 0 & 270 & 0 & 60 & 30 & 100 & .9 \\
\hline & $04-18-89$ & 3.77 & 42 & 780 & 6.6 & 20.5 & 5 & 220 & -- & 46 & 26 & 93 & .8 \\
\hline & $04-12-90$ & 1.93 & 42 & 777 & 6.5 & 20.0 & 0 & 220 & -- & 47 & 25 & 95 & 1.1 \\
\hline \multirow[t]{10}{*}{$A V-334$} & $10-18-72$ & -- & 90 & 1,010 & -- & -- & -- & 440 & -- & 110 & 39 & -- & -- \\
\hline & $11-28-72$ & -- & 90 & 975 & -- & -- & -- & 410 & -- & 100 & 38 & -- & -- \\
\hline & $12-19-72$ & -- & 90 & 1,000 & -- & -- & -- & 400 & -- & 100 & 37 & -- & -- \\
\hline & $02-20-73$ & -- & 90 & 1,030 & -- & -- & -- & 380 & -- & 90 & 37 & -- & -- \\
\hline & $06-19-73$ & -- & 90 & 1,100 & 7.2 & 20.0 & -- & 390 & -- & 96 & 37 & -- & -- \\
\hline & $08-15-73$ & -- & 90 & -- & -- & -- & $\cdots$ & 440 & -- & -- & -- & -- & -- \\
\hline & $12-03-73$ & -- & 90 & 989 & -- & 20.5 & -- & 410 & -- & -- & -- & -- & -- \\
\hline & $02-15-74$ & -- & 90 & 982 & -- & -- & -- & 380 & -- & -- & $m$ & -- & -- \\
\hline & $03-23-74$ & 5.45 & 90 & 1,010 & 6.5 & -- & -- & 440 & -- & -- & -- & -- & -- \\
\hline & $07-02-74$ & 5.45 & 90 & 1,000 & 6.4 & -- & -- & 510 & -- & -- & -- & -- & -- \\
\hline
\end{tabular}


Table 1. Summary of chemical and physical analyses of water from wells completed in the Red River alluvial aquifer, Louisiana, 1965-92--continued

\begin{tabular}{|c|c|c|c|c|c|c|c|c|c|c|c|c|c|}
\hline $\begin{array}{l}\text { Alkalin- } \\
\text { ity, as } \\
\text { calcium } \\
\text { carbonate, } \\
\text { field } \\
(\mathrm{mg} / \mathrm{L} \text { as } \\
\left.\mathrm{CaCO}_{3}\right)\end{array}$ & $\begin{array}{l}\text { Sulfate, } \\
\text { dis- } \\
\text { solved } \\
(\mathrm{mg} / \mathrm{L} \\
\left.\text { as } \mathrm{SO}_{4}\right)\end{array}$ & $\begin{array}{l}\text { Chlo- } \\
\text { ride, } \\
\text { dis- } \\
\text { solved } \\
\text { (mg/L } \\
\text { as Cl) }\end{array}$ & $\begin{array}{l}\text { Fluo- } \\
\text { ride, } \\
\text { dis- } \\
\text { solved } \\
\text { (mg/L } \\
\text { as F) }\end{array}$ & $\begin{array}{l}\text { Silica, } \\
\text { dis- } \\
\text { soived } \\
\text { (rg/L } \\
\text { as } \\
\left.\mathrm{SiO}_{2}\right)\end{array}$ & $\begin{array}{l}\text { Solids, } \\
\text { residue } \\
\text { at } \\
100{ }^{\circ} \mathrm{C} \text {, } \\
\text { dis- } \\
\text { solved } \\
(\mathrm{mg} / \mathrm{L})\end{array}$ & $\begin{array}{l}\text { Solids, } \\
\text { sum of } \\
\text { constit- } \\
\text { uents, } \\
\text { dis- } \\
\text { solved } \\
\text { (mg/L) }\end{array}$ & $\begin{array}{l}\text { Nitro- } \\
\text { gen, } \\
\text { nitrite } \\
\text { dis- } \\
\text { solved } \\
\text { (mg/L } \\
\text { as } N \text { ) }\end{array}$ & $\begin{array}{l}\text { Nitro- } \\
\text { gen, } \\
\text { nitrate } \\
\text { total } \\
(\mathrm{mg} / \mathrm{L} \\
\left.\text { as } \mathrm{NO}_{3}\right)\end{array}$ & $\begin{array}{l}\text { Nitro- } \\
\text { gen, } \\
\text { nitrite } \\
\text { dis- } \\
\text { solved } \\
\text { (mg/L } \\
\left.\text { as } \mathrm{NO}_{2}\right)\end{array}$ & $\begin{array}{l}\text { Nitro- } \\
\text { gen, } \\
\text { nitrate } \\
\text { dis- } \\
\text { solved } \\
\text { (mg/L } \\
\text { as N) }\end{array}$ & $\begin{array}{c}\text { Nitro- } \\
\text { gen, } \\
\mathrm{NO}_{2}+\mathrm{NO}_{3} \\
\text { dis- } \\
\text { solved } \\
\text { (mg/L } \\
\text { as } \mathrm{N} \text { ) }\end{array}$ & $\begin{array}{l}\text { Iron, } \\
\text { dis- } \\
\text { solved } \\
\text { (mg/L } \\
\text { as } \mathrm{Fe} \text { ) }\end{array}$ & $\begin{array}{l}\text { Manga- } \\
\text { nese, } \\
\text { dis- } \\
\text { solved } \\
\text { (mg/L } \\
\text { as } M n \text { ) }\end{array}$ \\
\hline-- & -- & 30 & -- & -- & -- & - & -- & -- & -- & -- & -- & -- & -- \\
\hline -- & 8.6 & 13 & -- & -- & -- & -- & -- & -- & -- & -- & -- & 5.8 & -- \\
\hline 660 & 9.4 & 13 & $<0.1$ & 38 & 740 & 720 & -- & 1.2 & -- & -- & -- & 17 & 1.8 \\
\hline -- & 16 & 15 & -- & -- & -- & -- & - & -- & -- & -- & -- & 7.9 & -- \\
\hline 850 & 8.0 & 12 & 1.0 & 36 & -- & 913 & -- & .04 & -- & -- & -- & 20 & 2.1 \\
\hline -- & 11 & 14 & -- & -- & -- & -- & -- & -- & -- & -- & -- & 19 & -- \\
\hline-- & 3.0 & 21 & -- & -- & -- & -- & -- & -- & -- & -- & -- & 22 & 2.1 \\
\hline -- & 8.0 & 14 & -- & -- & -- & -- & -- & -- & -- & -- & -- & 19 & 1.8 \\
\hline-- & 6.2 & 13 & -- & -- & -- & -- & -- & -- & -- & -- & -- & 20 & 2.2 \\
\hline-- & 6.2 & 14 & -- & -- & -- & -- & -- & -- & -- & -- & -- & 18 & 2.1 \\
\hline -- & 4.4 & 13 & -- & -- & -- & -- & -- & -- & -- & -- & -- & 19 & 1.8 \\
\hline 860 & 8.0 & 12 & .4 & 41 & -- & 929 & 0.59 & -- & 1.9 & 0.01 & 0.6 & 18 & 2.2 \\
\hline 800 & 5.8 & 13 & .3 & 36 & 903 & 828 & -- & .0 & -- & -- & -- & -- & 1.7 \\
\hline-- & 39 & 13 & -- & -- & -- & -- & -- & -- & -- & -- & -- & 18 & 1.8 \\
\hline-- & 3.6 & 12 & -- & -- & -- & -- & -- & -- & -- & -- & -- & 26 & 1.9 \\
\hline-- & 8.0 & 14 & -- & -- & -- & -- & -- & -- & -- & -- & -- & 18 & 1.9 \\
\hline -- & 10 & 14 & -- & -- & -- & -- & -- & -- & -- & -- & -- & -- & 1.3 \\
\hline 890 & 6.8 & 10 & .3 & 54 & 888 & 947 & -- & .28 & -- & -- & -- & 18 & 2.0 \\
\hline-- & 3.8 & 9.4 & -- & -- & -- & -- & -- & -- & -- & -- & -- & 18 & 1.9 \\
\hline-- & 22 & 15 & -- & -- & -- & -- & -- & -- & -- & -- & -- & 20 & 3.0 \\
\hline- & 16 & 13 & -- & -- & -- & -- & - & -- & -- & -- & -- & -- & 1.5 \\
\hline-- & 10 & 18 & -- & -- & -- & -- & -- & -- & -- & -- & - & -- & -- \\
\hline-- & 18 & 14 & -- & -- & -- & -- & -- & -- & -- & -- & -- & 14 & 1.2 \\
\hline-- & 13 & 13 & -- & -- & -- & -- & -- & -- & -- & -- & -- & 13 & 1.3 \\
\hline-- & 9.8 & 14 & -- & -- & -- & -- & -- & -- & -- & -- & -- & 14 & 1.4 \\
\hline-- & 16 & 18 & -- & -- & -- & -- & -- & -- & -- & -- & -- & 15 & 1.5 \\
\hline-- & 10 & 12 & -- & -- & -- & -- & -- & -- & -- & -- & -- & 17 & 1.6 \\
\hline-- & 11 & 11 & -- & -- & -- & -- & -- & -- & -- & -- & -- & 16 & 1.5 \\
\hline 750 & 9.0 & 11 & -- & -- & -- & -- & -- & -- & -- & -- & -- & 16 & 2.0 \\
\hline 786 & 11 & 13 & .3 & 45 & 749 & 826 & $<.01$ & -- & -- & -- & $<.02$ & 16 & 2.4 \\
\hline 120 & 580 & 280 & .2 & 37 & 1,560 & 1,420 & -- & -- & -- & -- & -- & .60 & .20 \\
\hline-- & 430 & 140 & -- & -- & -- & -- & -- & -- & + & -- & -- & .65 & -- \\
\hline 130 & 410 & 140 & .3 & 42 & 1,020 & 967 & -- & .03 & -- & -- & -- & .69 & .03 \\
\hline-- & 690 & 300 & -- & -- & -- & -- & -- & -- & -- & -- & -- & 1.1 & .09 \\
\hline 293 & 120 & 7.5 & .5 & 37 & 511 & 539 & $<.01$ & -- & -- & -- & 1.5 & .23 & .24 \\
\hline 314 & 99 & 6.8 & .3 & 37 & 495 & 511 & $<.01$ & -- & -- & -- & 3.0 & .16 & .02 \\
\hline 290 & 100 & 5.8 & .4 & 38 & 507 & 490 & $<.01$ & -- & -- & -- & .73 & .21 & .03 \\
\hline-- & -- & 44 & -- & -- & -- & -- & -- & -- & -- & -- & - & -. & -- \\
\hline-- & -- & 46 & -- & -- & -- & -- & -- & -- & -- & -- & -- & -- & -- \\
\hline-- & -- & 43 & -- & -- & -- & -- & -- & -- & -- & -- & -- & -- & -- \\
\hline-- & -- & 44 & -- & -- & -- & -- & -- & -- & -- & -- & -- & -- & -- \\
\hline-- & -- & 36 & -- & -- & -- & -- & -- & -- & -- & -- & -- & -- & -- \\
\hline-- & -- & 34 & -- & -- & -- & -- & -- & -- & -- & -- & -- & -- & - \\
\hline-- & 8.4 & 84 & -- & -- & -- & -- & -- & -- & -- & -- & -- & 16 & -- \\
\hline-- & 13 & 46 & -- & -- & -- & -- & -- & -- & -- & -- & -- & -- & -- \\
\hline-- & 4.4 & 47 & -- & -- & -- & -- & -- & -- & -- & -- & -- & 14 & -- \\
\hline-- & .8 & 42 & -- & -- & -- & -- & -- & -- & -- & -- & -- & 15 & -- \\
\hline
\end{tabular}


Table 1. Summary of chemical and physical analyses of water from wells completed in the Red River alluvial aquifer, Louisiana, 1965-92--continued

\begin{tabular}{|c|c|c|c|c|c|c|c|c|c|c|c|c|c|}
\hline $\begin{array}{c}\text { We } 11 \\
\text { no. }\end{array}$ & Date & $\begin{array}{l}\text { Water } \\
\text { level } \\
\text { below } \\
\text { land } \\
\text { sur- } \\
\text { face } \\
\text { (ft) }\end{array}$ & $\begin{array}{l}\text { Depth } \\
\text { of } \\
\text { well, } \\
\text { total } \\
\text { (ft) }\end{array}$ & $\begin{array}{l}\text { Spe- } \\
\text { cific } \\
\text { con- } \\
\text { duct- } \\
\text { ance } \\
(\mu \mathrm{s} / \mathrm{cm})\end{array}$ & $\begin{array}{l}\mathrm{pH}, \\
\text { field } \\
\text { (stand- } \\
\text { ard } \\
\text { units) }\end{array}$ & $\begin{array}{l}\text { Temper- } \\
\text { ature of } \\
\text { water } \\
\left({ }^{\circ} \mathrm{C}\right)\end{array}$ & $\begin{array}{l}\text { Color } \\
\text { (plat- } \\
\text { inum- } \\
\text { cobalt } \\
\text { units) }\end{array}$ & $\begin{array}{l}\text { Hard- } \\
\text { ness, } \\
\text { total } \\
\text { (mg/L } \\
\text { as } \\
\mathrm{CaCO}_{3} \text { ) }\end{array}$ & $\begin{array}{l}\text { Hard- } \\
\text { ness, } \\
\text { noncarb } \\
\text { whole } \\
\text { water } \\
\text { total } \\
\text { fleld } \\
\text { (mg/L as } \\
\mathrm{CaCO}_{3} \text { ) }\end{array}$ & $\begin{array}{c}\text { Calcium, } \\
\text { dis- } \\
\text { solved } \\
\langle\mathrm{mg} / \mathrm{L} \\
\text { as Ca〉 }\end{array}$ & $\begin{array}{l}\text { Magne- } \\
\text { sium, } \\
\text { dis- } \\
\text { solved } \\
\text { (mg/L } \\
\text { as Mg) }\end{array}$ & $\begin{array}{l}\text { Sodium, } \\
\text { dls- } \\
\text { solved } \\
\text { (mg/L } \\
\text { as } \mathrm{Na} \text { ) }\end{array}$ & $\begin{array}{l}\text { Potas- } \\
\text { sium, } \\
\text { dis- } \\
\text { solved } \\
\text { (mg/L } \\
\text { as K) }\end{array}$ \\
\hline \multirow[t]{37}{*}{$A v-334$} & $08-23-74$ & 22.19 & 90 & 1,020 & 6.9 & - & $-\infty$ & 510 & -- & -- & -- & -- & -- \\
\hline & $09-24-74$ & 13.48 & 90 & 1,000 & 6.7 & -- & 20 & 440 & 0 & 110 & 39 & 32 & 4.7 \\
\hline & $10-23-74$ & 18.52 & 90 & 1,000 & 6.8 & -- & -- & -- & -- & -- & -- & -- & -- \\
\hline & $11-19-74$ & 9.29 & 90 & 991 & 6.8 & -- & -- & -- & -- & -- & -- & -- & -- \\
\hline & $12-16-74$ & 6.83 & 90 & 975 & 6.4 & -- & -- & 420 & -- & -- & -- & -- & -- \\
\hline & $01-17-75$ & 5.35 & 90 & 1,010 & 6.4 & -- & -- & 400 & -- & -- & -- & -- & -- \\
\hline & $02-11-75$ & 3.14 & 90 & 972 & 6.8 & -- & $-\sim$ & 390 & -- & -- & -- & -- & -- \\
\hline & $03-05-75$ & 2.69 & 90 & 972 & 6.6 & -- & -- & 400 & -- & -- & -- & -- & -- \\
\hline & $04-05-75$ & +0.79 & 90 & 1,000 & 6.7 & -- & 15 & 410 & 0 & 100 & 40 & 47 & 3.5 \\
\hline & $05-24-75$ & +1.02 & 90 & 1,000 & 6.8 & 21.5 & -- & 410 & -- & 100 & 40 & -- & -- \\
\hline & $06-18-75$ & .80 & 90 & 978 & 6.8 & $-\sim$ & -- & 400 & -- & -- & $\sim$ & -- & $-\infty$ \\
\hline & $07-24-75$ & 14.95 & 90 & 1,010 & -- & -- & -- & 380 & -- & -- & -- & -- & -- \\
\hline & $10-27-75$ & 24.23 & 90 & 1,020 & 6.8 & -- & 5 & 440 & 0 & 110 & 39 & 46 & 4.4 \\
\hline & $03-22-76$ & 11.45 & 90 & -- & 6.8 & -- & -- & 400 & -- & -- & -- & -- & -- \\
\hline & $05-27-76$ & 18.05 & 90 & -- & 6.9 & -- & -- & 390 & 41 & 100 & 35 & 50 & 3.3 \\
\hline & $08-16-76$ & 23.82 & 90 & -- & 6.9 & -- & 20 & 430 & 0 & 100 & 43 & 45 & 4.1 \\
\hline & $11-04-76$ & 26.11 & 90 & -- & 6.6 & -- & 15 & 440 & 0 & 110 & 39 & 44 & 4.0 \\
\hline & $03-29-77$ & 14.12 & 90 & -- & 6.9 & -- & -- & 410 & -- & -- & -- & -- & -- \\
\hline & $09-15-77$ & 26.73 & 90 & -- & -- & -- & -- & 400 & -- & -- & -- & -- & -- \\
\hline & $03-27-78$ & 18.45 & 90 & -- & 6.6 & -- & 5 & 400 & 0 & 96 & 40 & 46 & 4.2 \\
\hline & $09-22-78$ & 28.07 & 90 & -- & -- & -- & -- & 430 & -- & -- & -- & -- & -- \\
\hline & $03-26-79$ & 15.63 & 90 & -- & 6.9 & $-\infty$ & -- & 400 & -- & -- & -- & -- & -- \\
\hline & $11-28-79$ & 29.07 & 90 & -- & -- & -- & -- & 400 & -- & -- & -- & -- & -- \\
\hline & $04-11-80$ & 17.95 & 90 & -- & 6.7 & -- & -- & 400 & -- & -- & -- & -- & -- \\
\hline & $09-18-80$ & 33.85 & 90 & -- & -- & -- & -- & 400 & -- & -- & -- & $\sim$ & -- \\
\hline & $04-27-81$ & 34.90 & 90 & -- & -- & -- & -- & 400 & -- & -- & -- & -- & -- \\
\hline & $09-29-81$ & 34.92 & 90 & -- & -- & -- & -- & 410 & -- & -- & -- & -- & -- \\
\hline & $04-20-82$ & 26.60 & 90 & -- & -- & -- & -- & 410 & $-\infty$ & -- & -- & -- & -- \\
\hline & $09-20-82$ & 32.18 & 90 & -- & -- & -- & -- & 410 & -- & -- & -- & -- & -- \\
\hline & $03-21-84$ & 12.83 & 90 & -- & 6.8 & -- & -- & 400 & -- & 99 & 38 & -- & -- \\
\hline & $10-24-84$ & 18.95 & 90 & -- & 6.8 & -- & -- & 450 & -- & 100 & 48 & -- & -- \\
\hline & $03-14-85$ & 8.12 & 90 & -- & 6.9 & -- & -- & 430 & -- & 110 & 38 & -- & -- \\
\hline & $10-08-85$ & 21.48 & 90 & -- & 6.9 & -- & -- & 460 & -- & 120 & 40 & -- & -- \\
\hline & $04-01-86$ & 13.88 & 90 & -- & 6.8 & 22.0 & -- & 470 & -- & 110 & 47 & -- & -- \\
\hline & $08-29-86$ & 16.47 & 90 & -- & 6.7 & -- & -- & 380 & -- & 90 & 38 & -- & -- \\
\hline & $03-26-87$ & 5.47 & 90 & 1,100 & 6.8 & 21.0 & -- & 460 & -- & 110 & 45 & -- & -- \\
\hline & $06-28-88$ & 16.39 & 90 & 1,090 & 6.7 & -- & 5 & 450 & -- & 120 & 36 & 58 & 4.0 \\
\hline \multirow[t]{6}{*}{$A V-339$} & $04-22-70$ & -- & 42 & 910 & 6.7 & -- & 1 & 300 & 120 & 68 & 31 & 77 & 1.1 \\
\hline & $09-23-74$ & -- & 42 & 895 & 6.2 & 20.0 & 0 & 300 & 140 & 69 & 31 & 56 & 2.7 \\
\hline & $03-07-75$ & $\sim$ & 42 & 904 & 6.3 & 20.5 & -- & 300 & -- & -- & -- & -- & -- \\
\hline & $06-24-88$ & 8.22 & 42 & 1,070 & 6.4 & -- & 5 & 380 & -- & 90 & 37 & 90 & 1.2 \\
\hline & $04-18-89$ & 5.20 & 42 & 1,110 & 6.3 & 20.5 & 0 & 390 & 220 & 89 & 40 & 90 & 1.2 \\
\hline & $04-12-90$ & 5.50 & 42 & 1,110 & 6.4 & 20.5 & 0 & 390 & -- & 88 & 42 & 95 & 1.5 \\
\hline \multirow[t]{5}{*}{$A V-364$} & $02-05-76$ & 22.72 & 42 & 1,590 & 6.9 & -- & 5 & 880 & 0 & 220 & 80 & 29 & 3.3 \\
\hline & $03-22-76$ & 15.39 & 42 & -- & 7.0 & -- & $\cdots$ & 900 & -- & -- & -- & -- & -- \\
\hline & $05-27-76$ & 17.44 & 42 & -- & 7.1 & -- & -- & 920 & 0 & 250 & 71 & 38 & 2.2 \\
\hline & $11-03-76$ & 26.85 & 42 & -- & -- & -- & 5 & 930 & 36 & 250 & 75 & 29 & 2.3 \\
\hline & $03-29-77$ & 19.07 & 42 & -- & 7.0 & -- & -- & 930 & -- & -- & -- & -- & -- \\
\hline
\end{tabular}


Table 1. Summary of chemical and physical analyses of water from wells completed in the Red River alluvial aquifer, Louisiana, 1965-92--continued

\begin{tabular}{|c|c|c|c|c|c|c|c|c|c|c|c|c|c|}
\hline $\begin{array}{l}\text { Alkalin- } \\
\text { ity, as } \\
\text { calcium } \\
\text { carbonate, } \\
\text { field } \\
(\mathrm{mg} / \mathrm{L} \text { as } \\
\mathrm{CaCO} \text { ) }\end{array}$ & $\begin{array}{l}\text { Sulfate, } \\
\text { dis- } \\
\text { solved } \\
(\mathrm{mg} / \mathrm{I} \\
\left.\text { as } \mathrm{SO}_{4}\right)\end{array}$ & $\begin{array}{l}\text { Chlo- } \\
\text { ride, } \\
\text { dis- } \\
\text { solved } \\
\text { (mg/I } \\
\text { as Cl) }\end{array}$ & $\begin{array}{l}\text { Fluo- } \\
\text { ride, } \\
\text { dis- } \\
\text { solved } \\
\text { (mg/L } \\
\text { as F) }\end{array}$ & $\begin{array}{l}\text { Silica, } \\
\text { dis- } \\
\text { solved } \\
\text { (mg/L } \\
\text { as } \\
\mathrm{SiO}_{2} \text { ) }\end{array}$ & $\begin{array}{l}\text { Solids, } \\
\text { residue } \\
\text { at } \\
100^{\circ} \mathrm{C}, \\
\text { dis- } \\
\text { solved } \\
(\mathrm{mg} / \mathrm{L})\end{array}$ & $\begin{array}{l}\text { Solids, } \\
\text { sum of } \\
\text { constit- } \\
\text { uents, } \\
\text { dis- } \\
\text { solved } \\
\text { (mg/L) }\end{array}$ & $\begin{array}{l}\text { Nitro- } \\
\text { gen, } \\
\text { nitrite } \\
\text { dis- } \\
\text { solved } \\
\text { (mg/I } \\
\text { as N) }\end{array}$ & $\begin{array}{c}\text { Nitro- } \\
\text { gen, } \\
\text { nitrate } \\
\text { total } \\
\text { (mg/L } \\
\text { as } \mathrm{NO}_{3} \text { ) }\end{array}$ & $\begin{array}{l}\text { Nitro- } \\
\text { gen, } \\
\text { nitrite } \\
\text { dis- } \\
\text { solved } \\
\text { (mg/L } \\
\text { as } \mathrm{NO}_{2} \text { ) }\end{array}$ & $\begin{array}{l}\text { Nitro- } \\
\text { gen, } \\
\text { nitrate } \\
\text { dis- } \\
\text { solved } \\
\text { (mg/L } \\
\text { as N) }\end{array}$ & $\begin{array}{l}\text { Nitro- } \\
\text { gen, } \\
\mathrm{NO}_{2}+\mathrm{NO}_{3} \\
\text { dis- } \\
\text { solved } \\
\text { (mg/L } \\
\text { as } \mathrm{N} \text { ) }\end{array}$ & $\begin{array}{l}\text { Iron, } \\
\text { dis- } \\
\text { solved } \\
\text { (mg/L } \\
\text { as Fe) }\end{array}$ & $\begin{array}{c}\text { Manga- } \\
\text { nese, } \\
\text { dis- } \\
\text { solved } \\
\text { (mg/I } \\
\text { as Mn) }\end{array}$ \\
\hline-- & 2.0 & 38 & -- & -- & -- & -- & -- & -- & -- & -- & -- & 15 & -- \\
\hline 450 & 2.2 & 41 & 0.1 & 38 & 555 & 554 & -- & -- & -- & -- & -- & 17 & 0.48 \\
\hline-- & 2.8 & 44 & -- & -- & -- & -- & -- & -- & -- & -- & -- & 16 & .46 \\
\hline-- & $<1.0$ & 43 & -- & -- & -- & -- & -- & -- & -- & -- & -- & 15 & .50 \\
\hline-- & 1.2 & 46 & -- & -- & -- & -- & -- & -- & -- & $-\infty$ & -- & 16 & .44 \\
\hline-- & $<1.0$ & 47 & -- & -- & -- & -- & -- & -- & -- & -- & -- & 16 & .46 \\
\hline-- & .4 & 49 & $-\cdots$ & -- & -- & -- & -- & -- & -- & -- & -- & 15 & .48 \\
\hline-- & $<1.0$ & 50 & -- & -- & -- & -- & -- & -- & -- & -- & -- & 15 & .42 \\
\hline 470 & $<1.0$ & 49 & .2 & 48 & 558 & 581 & 0.04 & -- & 0.13 & 0.0 & 0.04 & 16 & .46 \\
\hline-- & .9 & 48 & -- & -- & -- & -- & -- & -- & -- & -- & -- & 16 & .45 \\
\hline-- & .2 & 46 & -- & - & -- & -- & -- & -- & -- & -- & -- & 14 & .47 \\
\hline-- & 1.4 & 46 & -- & -- & -- & -- & -- & -- & -- & -- & -- & 15 & .43 \\
\hline 480 & .8 & 37 & .1 & 38 & 568 & 580 & -- & -- & -- & -- & -- & 14 & .48 \\
\hline-- & .2 & 98 & -- & -- & -- & -- & -- & -- & -- & -- & -- & 11 & -- \\
\hline 350 & 3.6 & 100 & .3 & 29 & 587 & 550 & -- & -- & -- & -- & -- & 16 & -- \\
\hline 490 & .2 & 43 & .2 & 41 & 561 & 585 & -- & -- & -- & -- & -- & 14 & .47 \\
\hline 460 & .2 & 36 & .3 & 41 & 584 & 565 & -- & -- & -- & -- & -- & 14 & .47 \\
\hline-- & 1.0 & 42 & -- & -- & -- & -- & -- & -- & -- & -- & -- & 16 & .44 \\
\hline-- & .8 & 43 & -- & -- & -- & -- & -- & -- & -- & -- & -- & -- & .47 \\
\hline 410 & 2.6 & 45 & .1 & 45 & 586 & 541 & -- & -- & -- & -- & -- & 15 & .46 \\
\hline-- & .4 & 40 & -- & -- & -- & -- & - & -- & -- & -- & -- & -- & .48 \\
\hline-- & $<.2$ & 54 & -- & -- & -- & -- & -- & -- & -- & -- & -- & 16 & .49 \\
\hline- & .6 & 51 & -- & - & -- & -- & -- & -- & -- & -- & -- & -- & .43 \\
\hline-- & .2 & 58 & -- & -- & -- & -- & -- & -- & -- & -- & -- & 16 & .50 \\
\hline-- & .4 & 52 & -- & -- & -- & -- & -- & -- & -- & -- & -- & -- & .38 \\
\hline-- & 2.0 & 62 & -- & -- & -- & -- & -- & -- & -- & - & -- & -- & .46 \\
\hline-- & .6 & 64 & -- & -- & -- & -- & -- & -- & -- & - & -- & -- & .44 \\
\hline-- & 1.2 & 71 & -- & -- & -- & -- & -- & -- & -- & -- & -- & -- & .50 \\
\hline-- & .4 & 64 & -- & -- & -- & -- & -- & -- & -- & -- & -- & -- & .53 \\
\hline-- & .4 & 97 & -- & -- & -- & -- & -- & -- & -- & -- & -- & 21 & .48 \\
\hline-- & .2 & 76 & -- & -- & -- & -- & -- & -- & -- & -- & -- & 21 & .48 \\
\hline-- & .6 & 84 & -- & -- & -- & - & -- & -- & -- & -- & -- & 19 & .52 \\
\hline-- & .6 & 76 & -- & -- & -- & -- & -- & -- & -- & -- & -- & 19 & .56 \\
\hline-- & .6 & 82 & -- & -- & -- & -- & -- & -- & -- & -- & -- & 20 & .54 \\
\hline-- & .4 & 76 & -- & -- & -- & -- & -- & -- & -- & -- & -- & 20 & .68 \\
\hline 500 & .4 & 83 & -- & -- & -- & -- & -- & -- & -- & - & -- & 19 & .60 \\
\hline 498 & 34 & 72 & .1 & 44 & 403 & 690 & $<.01$ & -- & -- & - & $<.02$ & 23 & .56 \\
\hline 170 & 200 & 65 & .2 & 41 & 617 & 589 & -- & -- & -- & $-\cdots$ & -- & .10 & 1.6 \\
\hline 160 & 190 & 61 & .4 & 47 & 592 & 555 & -- & -- & -- & $=$ & -- & .55 & 2.1 \\
\hline-- & 190 & 66 & -- & -- & -- & -- & -- & -- & -- & -- & -- & .85 & 2.6 \\
\hline 180 & 240 & 96 & $<.2$ & 47 & 754 & 712 & $<.01$ & -- & -- & -- & $<.02$ & .56 & 2.1 \\
\hline 169 & 250 & 110 & .2 & 54 & 755 & 738 & $<.01$ & -- & -- & -- & $<.02$ & .30 & 2.2 \\
\hline 175 & 250 & 120 & .2 & 56 & 761 & 1,660 & $<.01$ & -- & -- & -- & $<.02$ & .40 & 2.0 \\
\hline 950 & .2 & 14 & .4 & 36 & 982 & 973 & -- & -- & -- & -- & -- & 12 & 8.0 \\
\hline-- & $<1.0$ & 34 & -- & -- & -- & -- & -- & -- & -- & -- & -- & 14 & 10 \\
\hline 930 & -- & 14 & .5 & 29 & 969 & 985 & -- & -- & -- & -- & -- & 12 & 8.5 \\
\hline 910 & 1.4 & 20 & .3 & 32 & -- & 956 & -- & -- & -- & -- & -- & -- & -- \\
\hline-- & $<1.0$ & 15 & -- & -- & -- & -- & -- & -- & -- & -- & -- & 18 & 11 \\
\hline
\end{tabular}


Table 1. Summary of chemical and physical analyses of water from wells completed in the Red River alluvial aquifer, Louisiana, 1965-92--continued

\begin{tabular}{|c|c|c|c|c|c|c|c|c|c|c|c|c|c|}
\hline $\begin{array}{c}\text { Well } \\
\text { no. }\end{array}$ & Date & $\begin{array}{l}\text { Water } \\
\text { level } \\
\text { below } \\
\text { land } \\
\text { sur- } \\
\text { face } \\
\text { (ft) }\end{array}$ & $\begin{array}{l}\text { Depth } \\
\text { of } \\
\text { well, } \\
\text { total } \\
\text { (ft) }\end{array}$ & $\begin{array}{l}\text { Spe- } \\
\text { cific } \\
\text { con- } \\
\text { duct- } \\
\text { ance } \\
(\mu s / c m)\end{array}$ & $\begin{array}{c}\mathrm{pH}, \\
\text { fleld } \\
\text { (stand- } \\
\text { ard } \\
\text { units) }\end{array}$ & $\begin{array}{l}\text { Temper- } \\
\text { ature of } \\
\text { water } \\
\left({ }^{\circ} \mathrm{C}\right)\end{array}$ & $\begin{array}{l}\text { Color } \\
\text { (plat- } \\
\text { inum- } \\
\text { cobalt } \\
\text { units) }\end{array}$ & $\begin{array}{l}\text { Hard- } \\
\text { ness, } \\
\text { total } \\
\text { (mg/L } \\
\text { as } \\
\mathrm{CaCO}_{3} \text { ) }\end{array}$ & $\begin{array}{l}\text { Hard- } \\
\text { ness, } \\
\text { noncarb } \\
\text { whole } \\
\text { water } \\
\text { total } \\
\text { fleld } \\
\left(\mathrm{mg}_{\mathrm{L}} \mathrm{L} \text { as }\right. \\
\left.\mathrm{CaCO}_{3}\right)\end{array}$ & $\begin{array}{c}\text { Calcium, } \\
\text { dis- } \\
\text { solved } \\
\text { (mg/L } \\
\text { as Ca) }\end{array}$ & $\begin{array}{l}\text { Magne- } \\
\text { sium, } \\
\text { d1s- } \\
\text { solved } \\
\text { (mg/L } \\
\text { as Mg) }\end{array}$ & $\begin{array}{l}\text { Sodium, } \\
\text { dis- } \\
\text { solved } \\
\text { (mg/L } \\
\text { as Na) }\end{array}$ & $\begin{array}{l}\text { Potas- } \\
\text { s1um, } \\
\text { dis- } \\
\text { solved } \\
\text { (mg/L } \\
\text { as K) }\end{array}$ \\
\hline \multirow[t]{4}{*}{$A V-364$} & $09-15-77$ & 26.94 & 42 & -- & -- & -- & -- & 910 & - & - & -- & -- & - \\
\hline & $03-27-78$ & 20.34 & 42 & -- & 6.6 & -- & -- & 920 & - & -- & -- & -- & 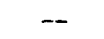 \\
\hline & $05-10-79$ & 18.64 & 42 & -- & 6.9 & -- & -- & 940 & -- & -- & -- & -- & -- \\
\hline & $10-13-87$ & 21.90 & 42 & -- & 6.9 & -- & 0 & 1,100 & -- & 300 & 80 & 35 & 2.0 \\
\hline \multirow[t]{40}{*}{$\mathrm{AV}-370$} & $05-14-74$ & 7.58 & 105 & 1,240 & 7.0 & -- & 5 & 600 & 27 & 140 & 60 & 38 & 3.9 \\
\hline & $08-23-74$ & 24.05 & 105 & 1,380 & 6.2 & -- & -- & 880 & -- & -- & -- & -- & - \\
\hline & $09-24-74$ & 16.35 & 105 & 1,360 & 6.8 & 21.0 & 5 & 760 & 66 & 190 & 69 & 18 & 4.5 \\
\hline & $10-21-74$ & 20.10 & 105 & 1,380 & 6.7 & 20.5 & -- & 740 & -- & -- & -- & - & -- \\
\hline & $11-18-74$ & 17.43 & 105 & 1,400 & 7.0 & 21.0 & -- & 730 & -- & -- & -- & -- & -- \\
\hline & $12-16-74$ & 9.49 & 105 & 1,430 & 6.5 & 20.0 & -- & 810 & -- & -- & -- & -- & - \\
\hline & $01-17-75$ & 7.42 & 105 & 1,430 & 6.9 & 20.5 & -- & 820 & -- & - & -- & -- & -- \\
\hline & $02-11-75$ & .5 .34 & 105 & 1,410 & 6.5 & 20.0 & -- & 760 & -- & - & -- & -- & -- \\
\hline & $03-05-75$ & 4.88 & 105 & 1,420 & -- & 20.0 & -- & 740 & -- & - & -- & -- & -- \\
\hline & $04-26-75$ & 1.50 & 105 & 1,480 & 6.4 & 20.5 & 5 & 840 & 53 & 200 & 83 & 34 & 3.6 \\
\hline & $06-03-75$ & 3.31 & 105 & 1,470 & 6.4 & 21.0 & 5 & 730 & 0 & 200 . & 56 & 45 & 3.8 \\
\hline & $07-23-75$ & 17.28 & 105 & 1,450 & 6.6 & 21.0 & -- & 740 & -- & -- & -- & -- & -- \\
\hline & $03-22-76$ & 14.46 & 105 & 1,160 & 6.9 & 20.5 & -- & 640 & -- & -- & -- & -- & -- \\
\hline & $05-27-76$ & 20.71 & 105 & -- & 7.3 & -- & -- & 630 & -- & -- & -- & -- & -- \\
\hline & $11-03-76$ & 29.06 & 105 & -- & -- & -- & 15 & 680 & 22 & 170 & 62 & 32 & 3.5 \\
\hline & $03-29-77$ & 19.82 & 105 & -- & 6.9 & -- & 0 & 670 & 0 & 160 & 65 & 32 & 4.0 \\
\hline & $09-15-77$ & 29.51 & 105 & -- & -- & -- & -- & 660 & -- & - & -- & -- & -- \\
\hline & $03-27-78$ & 20.82 & 105 & -- & 6.8 & -- & -- & 620 & -- & -- & -- & -- & -- \\
\hline & $09-22-78$ & -- & 105 & -- & -- & -- & -- & 670 & - & -- & -- & -- & -- \\
\hline & $05-10-79$ & 21.54 & 105 & -- & 6.9 & -- & -- & 680 & -- & - & - & -- & -- \\
\hline & $11-29-79$ & 41.01 & 105 & -- & -- & -- & -- & 470 & -- & -- & -- & -- & -- \\
\hline & $04-16-80$ & 31.24 & 105 & -- & -- & - & -- & 420 & -- & -- & -- & -- & -- \\
\hline & $09-18-80$ & 45.64 & 105 & -- & -- & -- & -- & 380 & -- & -- & -- & -- & -- \\
\hline & $04-27-81$ & 46.86 & 105 & -- & -- & -- & -- & 360 & -- & -- & -- & -- & -- \\
\hline & $09-29-81$ & 46.81 & 105 & -- & -- & -- & -- & 340 & -- & -- & -- & -- & -- \\
\hline & $04-20-82$ & 38.55 & 105 & -- & -- & -- & -- & 330 & -- & -- & - & -- & -- \\
\hline & $09-20-82$ & 41.05 & 105 & -- & -- & -- & -- & 300 & -- & -- & -- & - & -- \\
\hline & $04-18-83$ & 29.79 & 105 & -- & -- & - & -- & 290 & -- & 72 & 26 & - & - \\
\hline & $09-23-83$ & 40.98 & 105 & -- & -- & -- & -- & 320 & -- & 77 & 30 & -- & -- \\
\hline & $03-21-84$ & 18.27 & 105 & -- & 6.8 & 20.0 & -- & 300 & -- & 74 & 28 & -- & -- \\
\hline & $10-24-84$ & 24.30 & 105 & - & 7.0 & 24.0 & -- & 330 & -- & 73 & 35 & -- & -- \\
\hline & $03-14-85$ & 11.81 & 105 & -- & 6.9 & -- & -- & 330 & -- & 81 & 30 & -- & -- \\
\hline & $10-08-85$ & 26.16 & 105 & -- & 7.1 & 22.0 & -- & 350 & -- & 85 & 34 & -- & -- \\
\hline & $04-01-86$ & 18.92 & 105 & -- & 7.0 & 21.0 & -- & 370 & -- & 90 & 35 & -- & - \\
\hline & $08-29-86$ & 23.55 & 105 & - & 6.8 & 21.0 & -- & 310 & -- & 73 & 30 & -- & -- \\
\hline & $03-26-87$ & 7.37 & 105 & 690 & 7.1 & 20.0 & -- & 320 & -- & 80 & 30 & -- & - \\
\hline & $10-13-87$ & 24.80 & 105 & -- & 7.2 & -- & 0 & 300 & -- & 72 & 30 & 20 & 4.0 \\
\hline & $04-19-89$ & 11.74 & 105 & 665 & 7.0 & 20.5 & 10 & 330 & -- & 77 & 33 & 22 & 3.1 \\
\hline & $03-26-91$ & 14.02 & 105 & 687 & 6.9 & 20.5 & 5 & 310 & - & 72 & 31 & 22 & 3.6 \\
\hline & $04-28-92$ & 15.73 & 105 & 1,220 & 6.8 & 20.0 & -- & 640 & -- & 170 & 52 & 24 & 4.1 \\
\hline
\end{tabular}


Table 1. Summary of chemical and physical analyses of water from wells completed in the Red River alluvial aquifer, Louisiana, 1965-92--continued

\begin{tabular}{|c|c|c|c|c|c|c|c|c|c|c|c|c|c|}
\hline $\begin{array}{l}\text { Alkalin- } \\
\text { ity, as } \\
\text { calcium } \\
\text { carbonate, } \\
\text { field } \\
(\mathrm{mg} / \mathrm{L} \text { as } \\
\left.\mathrm{CaCO}_{3}\right)\end{array}$ & $\begin{array}{l}\text { Sulfate, } \\
\text { dis- } \\
\text { solved } \\
\text { (mg/L } \\
\left.\text { as } \mathrm{SO}_{4}\right)\end{array}$ & $\begin{array}{l}\text { Chlo- } \\
\text { ride, } \\
\text { dis- } \\
\text { solved } \\
\text { \{mg/L } \\
\text { as Cl\} }\end{array}$ & $\begin{array}{l}\text { Fluo- } \\
\text { ride, } \\
\text { dis- } \\
\text { solved } \\
\text { (mg/L } \\
\text { as F) }\end{array}$ & $\begin{array}{l}\text { Silica, } \\
\text { dis- } \\
\text { solved } \\
\text { (mg/L } \\
\text { as } \\
\mathrm{SiO}_{2} \text { ) }\end{array}$ & $\begin{array}{l}\text { Solids, } \\
\text { residue } \\
\text { at } \\
100{ }^{\circ} \mathrm{C}, \\
\text { dis- } \\
\text { solved } \\
\text { (mg/L) }\end{array}$ & $\begin{array}{l}\text { solids, } \\
\text { sum of } \\
\text { constit- } \\
\text { uents, } \\
\text { dis- } \\
\text { solved } \\
\text { (mg/L) }\end{array}$ & $\begin{array}{l}\text { Nitro- } \\
\text { gen, } \\
\text { nitrite } \\
\text { dis- } \\
\text { solved } \\
\text { (mg/L } \\
\text { as } N \text { ) }\end{array}$ & $\begin{array}{c}\text { Nitro- } \\
\text { gen, } \\
\text { nitrate } \\
\text { total } \\
\text { (mg/L } \\
\text { as } \mathrm{NO}_{3} \text { ) }\end{array}$ & $\begin{array}{l}\text { Nitro- } \\
\text { gen, } \\
\text { nitrite } \\
\text { dis- } \\
\text { solved } \\
\langle\mathrm{mg} / \mathrm{L} \\
\left.\text { as } \mathrm{NO}_{2}\right\rangle\end{array}$ & $\begin{array}{l}\text { Nitro- } \\
\text { gen, } \\
\text { nitrate } \\
\text { dis- } \\
\text { solved } \\
\text { (mg/L } \\
\text { as } N)\end{array}$ & $\begin{array}{l}\text { Nitro- } \\
\text { gen, } \\
\mathrm{NO}_{2}+\mathrm{NO}_{3} \\
\text { dis- } \\
\text { solved } \\
\text { (mg/L } \\
\text { as N) }\end{array}$ & $\begin{array}{l}\text { Iron, } \\
\text { dis- } \\
\text { solved } \\
\text { (mg/L } \\
\text { as Fe) }\end{array}$ & $\begin{array}{l}\text { Manga- } \\
\text { nese, } \\
\text { dls- } \\
\text { solved } \\
\text { (mg/L } \\
\text { as Mn) }\end{array}$ \\
\hline -- & 8.4 & 27 & -- & -- & -- & -- & -- & -- & -- & -- & -- & -- & -- \\
\hline-- & $<.2$ & 22 & -- & -- & -- & -- & -- & -- & -- & -- & -- & 16 & 12 \\
\hline-- & $<.2$ & 30 & -- & -- & -- & -- & - & -- & -- & -- & -- & 15 & 11 \\
\hline 975 & 1.2 & 79 & 0.1 & 26 & 896 & 1,160 & -- & - & -- & -- & -- & -- & 11 \\
\hline 560 & 79 & 20 & .1 & 42 & 750 & 737 & - & -- & -- & -- & -- & 18 & 1.4 \\
\hline-- & 71 & 16 & -- & - & -- & -- & -- & -- & -- & -- & -- & 16 & - \\
\hline 690 & 44 & 16 & .1 & 37 & 810 & 814 & -- & -- & -- & -- & -- & 18 & 1.7 \\
\hline-- & 73 & 18 & -- & -- & -- & -- & -- & -- & -- & -- & -- & 18 & 1.3 \\
\hline-- & 48 & 20 & -- & -- & -- & -- & -- & -- & -- & -- & -- & 18 & 1.5 \\
\hline-- & 78 & 18 & -- & -- & -- & -- & -- & -- & -- & -- & -- & 18 & 1.5 \\
\hline-- & 73 & 17 & -- & -- & -- & -- & -- & -- & -- & -- & -- & 19 & 1.8 \\
\hline-- & 78 & 18 & -- & -- & -- & -- & -- & -- & -- & -- & -- & 18 & 1.5 \\
\hline-- & 72 & 18 & -- & -- & -- & -- & -- & -- & -- & -- & -- & 20 & 1.5 \\
\hline 790 & 78 & 17 & .3 & 46 & 919 & 953 & $<0.01$ & -- & 0.0 & -- & 0.01 & 17 & 1.6 \\
\hline 730 & 75 & 21 & .2 & 43 & 923 & 885 & -- & -- & -- & -- & -- & -- & 1.4 \\
\hline-- & 91 & 18 & -- & -- & -- & -- & -- & -- & -- & -- & -- & 18 & 1.4 \\
\hline-- & 28 & 21 & -- & -- & -- & -- & -- & -- & -- & -- & -- & 15 & 1.3 \\
\hline-- & 24 & 21 & -- & -- & -- & -- & -- & -- & -- & -- & -- & 15 & 1.2 \\
\hline 660 & 64 & 18 & .3 & 31 & 619 & 778 & -- & -- & -- & -- & -- & -- & -- \\
\hline 680 & 53 & 16 & .2 & 60 & 758 & 815 & -- & -- & -- & -- & -- & 15 & 1.4 \\
\hline-- & 51 & 15 & -- & -. & -- & -- & -- & -- & -- & - & -- & -- & -- \\
\hline-- & 46 & 14 & -- & -- & -- & -- & -- & -- & -- & -- & -- & 14 & 1.4 \\
\hline-- & 22 & 15 & -- & -- & -- & -- & -- & - & -- & -- & -- & -- & -- \\
\hline-- & 34 & 24 & -- & -- & -- & -- & -- & -- & - & -- & -- & 12 & 1.6 \\
\hline-- & -- & 26 & -- & -- & -- & -- & - & -- & -- & -- & -- & -- & .68 \\
\hline -- & 4.4 & 22 & -- & -- & -- & -- & -- & -- & -- & -- & -- & -- & -- \\
\hline-- & 7.8 & 13 & -- & -- & -- & -- & -- & -- & -- & -- & -- & -- & .70 \\
\hline-- & -- & 9.9 & -- & -- & -- & -- & -- & -- & -- & -- & -- & -- & -- \\
\hline-- & -- & 9.4 & -- & -- & -- & -- & -- & -- & -- & -- & -- & -- & -- \\
\hline-- & 2.4 & 9.3 & -- & -- & -- & -- & -- & -- & -- & -- & -- & -- & -- \\
\hline-- & 11 & 3.3 & -- & -- & -- & -- & -- & -- & -- & -- & -- & -- & -- \\
\hline-- & 8.8 & 1.0 & -- & -- & -- & -- & -- & -- & -- & -- & -- & -- & -- \\
\hline-- & 4.7 & 29 & -- & -- & -- & -- & -- & -- & -- & -- & -- & -- & .42 \\
\hline-- & 13 & 4.8 & -- & -- & -- & -- & - & -- & -- & -- & -- & 6.80 & .43 \\
\hline-- & 12 & 2.8 & -- & -- & -- & -- & -- & -- & -- & -- & -- & 6.90 & .60 \\
\hline -- & 12 & 2.2 & -- & -- & -- & -- & -- & -- & -- & -- & -- & 6.70 & .48 \\
\hline-- & -- & 10 & -- & -- & -- & -- & -- & -- & -- & -- & -- & 8.0 & .38 \\
\hline-- & 2.2 & 9.3 & -- & -- & -- & -- & -- & -- & -- & -- & -- & 7.50 & .52 \\
\hline-- & .80 & 4.0 & -- & -- & -- & -- & -- & -- & -- & -- & -- & 7.50 & .56 \\
\hline 360 & .60 & 3.0 & -- & -- & -- & -- & -- & -- & -- & -- & -- & 6.80 & .42 \\
\hline 364 & .80 & 4.3 & .2 & 51 & 385 & 408 & -- & -- & -- & -- & -- & 7.00 & .76 \\
\hline 367 & .20 & 10 & .2 & 50 & 406 & 422 & $<.01$ & -- & -- & -- & $<.02$ & 5.70 & .81 \\
\hline 385 & $<.20$ & 9.6 & .3 & 51 & 409 & -- & $<.01$ & -- & -- & -- & .02 & 6.70 & .66 \\
\hline 694 & 13 & 13 & .3 & 46 & 706 & 755 & $<.01$ & -- & -- & -- & .02 & 14 & 2.0 \\
\hline
\end{tabular}


Table 1. Summary of chemical and physical analyses of water from wells completed in the Red River alluvial aquifer, Louisiana, 1965-92--continued

\begin{tabular}{|c|c|c|c|c|c|c|c|c|c|c|c|c|c|}
\hline $\begin{array}{c}\text { Well } \\
\text { no. }\end{array}$ & Date & $\begin{array}{l}\text { Water } \\
\text { level } \\
\text { below } \\
\text { land } \\
\text { sur- } \\
\text { face } \\
\text { (ft) }\end{array}$ & $\begin{array}{l}\text { Depth } \\
\text { of } \\
\text { well, } \\
\text { total } \\
\text { (ft) }\end{array}$ & $\begin{array}{l}\text { Spe- } \\
\text { cific } \\
\text { con- } \\
\text { duct- } \\
\text { ance } \\
(\mu \mathrm{s} / \mathrm{cm})\end{array}$ & $\begin{array}{l}\text { pH, } \\
\text { field } \\
\text { (stand- } \\
\text { ard } \\
\text { units) }\end{array}$ & $\begin{array}{l}\text { Temper- } \\
\text { ature of } \\
\text { water } \\
\left.\quad{ }^{\circ} \mathrm{C}\right\rangle\end{array}$ & $\begin{array}{l}\text { Color } \\
\text { (plat- } \\
\text { inum- } \\
\text { cobalt } \\
\text { units) }\end{array}$ & $\begin{array}{l}\text { Hard- } \\
\text { ness, } \\
\text { total } \\
\text { (mg/L } \\
\text { as } \\
\mathrm{CaCO}_{3} \text { ) }\end{array}$ & $\begin{array}{l}\text { Hard- } \\
\text { ness, } \\
\text { noncarb } \\
\text { whole } \\
\text { water } \\
\text { total } \\
\text { field } \\
(\mathrm{mg} / \mathrm{L} \text { as } \\
\left.\mathrm{CaCO}_{3}\right)\end{array}$ & $\begin{array}{c}\text { Calcium, } \\
\text { dis- } \\
\text { solved } \\
\text { (mg/L } \\
\text { as Ca) }\end{array}$ & $\begin{array}{c}\text { Magne- } \\
\text { sium, } \\
\text { dis- } \\
\text { solved } \\
\text { (mg/L } \\
\text { as Mg) }\end{array}$ & $\begin{array}{l}\text { Sodium, } \\
\text { dis- } \\
\text { solved } \\
\text { (mg/L } \\
\text { as Na) }\end{array}$ & $\begin{array}{l}\text { Potas- } \\
\text { sium, } \\
\text { dis- } \\
\text { solved } \\
\text { (mg/L } \\
\text { as K) }\end{array}$ \\
\hline \multirow[t]{35}{*}{$A V-371$} & $09-24-74$ & 13.41 & 136 & 979 & 6.7 & - & 5 & 400 & 57 & 94 & 41 & 33 & 3.7 \\
\hline & $10-23-74$ & 18.57 & 136 & 976 & 7.0 & -- & -- & 400 & -- & -- & -- & -- & -- \\
\hline & $11-19-74$ & 9.11 & 136 & 915 & 7.1 & -- & -- & 380 & -- & -- & -- & -- & -- \\
\hline & $12-16-74$ & 6.78 & 136 & 842 & 6.7 & -- & -- & 340 & -- & -- & -- & -- & -- \\
\hline & $01-17-75$ & 5.33 & 136 & 875 & 7.2 & -- & - & 360 & - & -- & -- & - & -- \\
\hline & $02-11-75$ & 1.95 & 136 & 874 & 6.7 & -- & -- & 340 & -- & -- & - & -- & -- \\
\hline & $03-05-75$ & 2.65 & 136 & 824 & 7.2 & -- & -- & 320 & -- & -- & - & -- & -- \\
\hline & $04-05-75$ & .87 & 136 & 817 & 7.1 & -- & 7 & 320 & 0 & 81 & 28 & 42 & -- \\
\hline & $05-24-75$ & +1.07 & 136 & 807 & 7.1 & -- & -- & 320 & -- & 80 & 28 & -- & -- \\
\hline & $06-18-75$ & +0.77 & 136 & 780 & 7.1 & - & -- & 300 & -- & -- & - & -- & -- \\
\hline & $10-27-75$ & 24.23 & 136 & 882 & 7.1 & -- & 0 & 340 & 7 & 90 & 29 & 46 & 3.5 \\
\hline & $03-22-76$ & 11.47 & 136 & -- & 7.0 & -- & -- & 420 & -- & -- & - & -- & -- \\
\hline & $05-27-76$ & 17.92 & 136 & -- & 6.9 & -- & -- & 420 & 0 & 100 & 41 & 59 & 4.0 \\
\hline & $08-16-76$ & 23.90 & 136 & -- & 7.0 & -- & 10 & 440 & 42 & 110 & 39 & 55 & 3.5 \\
\hline & $11-04-76$ & 26.14 & 136 & -- & -- & -- & 20 & 410 & 45 & 110 & 33 & 51 & 2.9 \\
\hline & $01-20-77$ & 22.37 & 136 & -- & 6.9 & -- & -- & 420 & -- & -- & -- & -- & -- \\
\hline & $03-29-77$ & 16.79 & 136 & -- & 6.9 & -- & -- & 420 & -- & -- & -- & -- & -- \\
\hline & $09-15-77$ & 26.72 & 136 & -- & -- & -- & -- & 410 & -- & -- & -- & -- & -- \\
\hline & $03-27-78$ & 18.45 & 136 & -- & 6.8 & -- & 5 & 440 & 51 & 110 & 39 & 57 & 3.6 \\
\hline & $09-22-78$ & 28.07 & 136 & -- & -- & -- & - & 420 & -- & -- & -- & -- & -- \\
\hline & $03-26-79$ & 15.69 & 136 & -- & 6.9 & -- & -- & 370 & -- & -- & -- & -- & - \\
\hline & $11-29-79$ & 29.04 & 136 & -- & -- & -- & -- & 350 & -- & -- & -- & -- & -- \\
\hline & $04-11-80$ & 17.95 & 136 & -- & 6.9 & -- & -- & 340 & -- & -- & -- & -- & - \\
\hline & $09-18-80$ & 33.85 & 136 & -- & -- & -- & -- & 320 & -- & -- & -- & -- & -- \\
\hline & $04-27-81$ & 34.90 & 136 & -- & -- & -- & -- & 300 & -- & -- & -- & -- & -- \\
\hline & $09-29-81$ & 34.95 & 136 & -- & -- & -- & -- & 300 & -- & -- & -- & -- & -- \\
\hline & $04-20-82$ & 26.63 & 136 & -- & -- & -- & -- & 270 & -- & -- & -- & -- & -- \\
\hline & $09-20-82$ & 32.22 & 136 & -- & -- & -- & -- & 290 & -- & -- & -- & -- & -- \\
\hline & $03-21-84$ & 12.75 & 136 & -- & 6.9 & -- & -- & 280 & -- & 71 & 25 & -- & -- \\
\hline & $10-24-84$ & 18.97 & 136 & -- & 7.0 & -- & -- & 300 & -- & 68 & 31 & -- & -- \\
\hline & $03-14-85$ & 8.07 & 136 & -- & 7.1 & -- & -- & 320 & -- & 82 & 27 & -- & -- \\
\hline & $10-08-85$ & 21.53 & 136 & -- & 7.0 & -- & -- & 300 & -- & 67 & 31 & -- & -- \\
\hline & $04-01-86$ & 13.92 & 136 & -- & 6.9 & -- & -- & 320 & -- & 80 & 29 & -- & -- \\
\hline & $08-29-86$ & 16.45 & 136 & -- & 6.8 & -- & -- & 280 & -- & 71 & 26 & -- & -- \\
\hline & $03-26-87$ & 5.45 & 136 & 822 & 7.0 & -- & -- & 300 & -- & 75 & 27 & - & -- \\
\hline \multirow[t]{15}{*}{$\mathrm{AV}-372 \mathrm{~A}$} & $05-14-74$ & 7.87 & 173 & 1,390 & 6.8 & -- & 5 & 720 & 0 & 210 & 47 & 36 & 8.3 \\
\hline & $08-23-74$ & 24.36 & 173 & 1,410 & 6.4 & -- & -- & 860 & -- & -- & -- & -- & -- \\
\hline & $09-24-74$ & 16.68 & 173 & 1,410 & 7.0 & 21.0 & 5 & 740 & 2 & 190 & 64 & 27 & 5.2 \\
\hline & $10-21-74$ & 20.43 & 1.73 & 1,400 & 6.6 & 20.5 & -- & 730 & -- & -- & -- & -- & -- \\
\hline & $11-18-74$ & 13.45 & 173 & 1,390 & 6.8 & 20.5 & -- & 740 & -- & -- & -- & -- & -- \\
\hline & $12-16-74$ & 9.84 & 173 & 1,400 & 6.4 & 20.5 & -- & 750 & -- & -- & -- & -- & -- \\
\hline & $01-17-75$ & 6.77 & 173 & 1,410 & 6.8 & 20.5 & -- & 740 & -- & -- & -- & -- & -- \\
\hline & $02-11-75$ & 5.73 & 173 & 1,400 & 6.7 & 20.0 & -- & 720 & -- & -- & -- & -- & -- \\
\hline & $03-05-75$ & 5.20 & 173 & 1,400 & 6.9 & 20.0 & -- & 720 & -- & -- & -- & -- & -- \\
\hline & $04-26-75$ & 1.93 & 173 & 1,430 & 6.2 & 20.5 & 5 & 750 & 0 & 190 & 66 & 42 & -- \\
\hline & $06-03-75$ & .80 & 173 & 1,440 & 6.6 & 20.5 & 5 & 670 & -- & 200 & 42 & 40 & 6.8 \\
\hline & $07-23-75$ & 12.65 & 173 & 1,460 & 6.7 & 21.0 & -- & 690 & -- & -- & -- & -- & - \\
\hline & $03-22-76$ & 14.37 & 173 & -- & 7.0 & -- & -- & 760 & -- & -- & -- & -- & - \\
\hline & $05-27-76$ & 20.65 & 173 & -- & 7.1 & -- & -- & 800 & -- & -- & - & -- & -- \\
\hline & $11-04-76$ & 28.98 & 173 & -- & -- & -- & 5 & 740 & 0 & 190 & 64 & 41 & 7.5 \\
\hline
\end{tabular}


Table 1. Summary of chemical and physical analyses of water from wells completed in the Red River alluvial aquifer, Louisiana, 1965-92--continued

\begin{tabular}{|c|c|c|c|c|c|c|c|c|c|c|c|c|c|}
\hline $\begin{array}{c}\text { Alkalin- } \\
\text { ity, as } \\
\text { calcium } \\
\text { carbonate, } \\
\text { Eield } \\
\text { (mg/L as } \\
\mathrm{CaCO})\end{array}$ & $\begin{array}{l}\text { sulfate, } \\
\text { dis- } \\
\text { solved } \\
(\mathrm{mg} / \mathrm{L} \\
\left.\text { as } \mathrm{SO}_{4}\right)\end{array}$ & $\begin{array}{l}\text { Chlo- } \\
\text { ride, } \\
\text { dis- } \\
\text { solved } \\
\text { (mg/L } \\
\text { as CI) }\end{array}$ & $\begin{array}{l}\text { Fluo- } \\
\text { ride, } \\
\text { dis- } \\
\text { solved } \\
\text { (mg/L } \\
\text { as F) }\end{array}$ & $\begin{array}{l}\text { Silica, } \\
\text { dis- } \\
\text { solved } \\
\text { (mg/L } \\
\text { as } \\
\mathrm{SiO}_{2} \text { ) }\end{array}$ & $\begin{array}{l}\text { Solids, } \\
\text { residue } \\
\text { at } \\
100{ }^{\circ} \mathrm{C}, \\
\text { dis- } \\
\text { solved } \\
(\mathrm{mg} / \mathrm{L})\end{array}$ & $\begin{array}{l}\text { Solids, } \\
\text { sum of } \\
\text { constit- } \\
\text { uents, } \\
\text { dis- } \\
\text { solved } \\
\text { (mg/L) }\end{array}$ & $\begin{array}{l}\text { Nitro- } \\
\text { gen, } \\
\text { nitrite } \\
\text { dis- } \\
\text { solved } \\
\text { (mg/L } \\
\text { as N) }\end{array}$ & $\begin{array}{c}\text { Nitro- } \\
\text { gen, } \\
\text { nitrate } \\
\text { total } \\
\text { (mg/L } \\
\text { as } \mathrm{NO}_{3} \text { ) }\end{array}$ & $\begin{array}{l}\text { Nitro- } \\
\text { gen, } \\
\text { nitrite } \\
\text { dis- } \\
\text { solved } \\
\text { (mg/L } \\
\left.\text { as } \mathrm{NO}_{2}\right)\end{array}$ & $\begin{array}{l}\text { Nitro- } \\
\text { gen, } \\
\text { nitrate } \\
\text { dis- } \\
\text { solved } \\
\text { (mg/L } \\
\text { as N) }\end{array}$ & $\begin{array}{l}\text { Nitro- } \\
\text { gen, } \\
\mathrm{NO}_{2}+\mathrm{NO}_{3} \\
\text { dis- } \\
\text { solved } \\
\text { (mg/L } \\
\text { as } \mathrm{N} \text { ) }\end{array}$ & $\begin{array}{l}\text { Iron, } \\
\text { dis- } \\
\text { solved } \\
\text { (mg/L } \\
\text { as Fe) }\end{array}$ & $\begin{array}{l}\text { Manga- } \\
\text { nese, } \\
\text { dis- } \\
\text { solved } \\
\text { (mg/L } \\
\text { as Mn) }\end{array}$ \\
\hline 340 & 3.6 & 100 & 0.2 & 28 & 562 & 528 & -- & -- & -- & -- & -- & 17 & 1.4 \\
\hline-- & 3.6 & 88 & - & -- & -- & -- & -- & -- & -- & -- & -- & 17 & 1.5 \\
\hline-- & 15 & 44 & -- & -- & -- & -- & -- & -- & -- & -- & -- & 13 & 1.4 \\
\hline-- & 2.6 & 66 & -- & -- & -- & -- & -- & -- & -- & -- & -- & 16 & .96 \\
\hline-- & 1.0 & 71 & -- & -- & -- & -- & -- & -- & -- & -- & -- & 17 & 1.4 \\
\hline-- & .8 & 76 & -- & -- & -- & -- & -- & -- & -- & -- & -- & 16 & .80 \\
\hline-- & $<1.0$ & 73 & -- & -- & -- & -- & -- & -- & -- & -- & -- & 16 & 1.5 \\
\hline 340 & $<1.0$ & 61 & .2 & 33 & 458 & 466 & $<0.01$ & -- & 0.0 & -- & 0.16 & 16 & 1.0 \\
\hline-- & .1 & 58 & -- & -- & -- & -- & -- & -- & -- & -- & -- & 16 & .94 \\
\hline-- & $<1.0$ & 54 & -- & -- & -- & -- & -- & -- & -- & -- & -- & 15 & .92 \\
\hline 340 & .8 & 75 & .2 & 18 & 495 & 480 & -- & -- & -- & -- & -- & 14 & 1.0 \\
\hline-- & $<1.0$ & 40 & -- & -- & -- & -- & -- & -- & -- & -- & -- & 15 & .48 \\
\hline 480 & 1.2 & 41 & .3 & 44 & 567 & 593 & -- & -- & -- & -- & -- & 15 & .44 \\
\hline 390 & $<1.0$ & 120 & .2 & 32 & 603 & 596 & -- & -- & -- & -- & -- & -- & 1.3 \\
\hline 360 & .2 & 110 & .3 & 37 & 581 & 560 & -- & -- & -- & -- & -- & -- & -- \\
\hline- & 1.8 & 110 & -- & -- & -- & -- & -- & -- & -- & -- & -- & 17 & 1.2 \\
\hline-- & 1.2 & 100 & -- & -- & -- & -- & -- & -- & -- & -- & -- & 17 & 1.3 \\
\hline-- & 2.8 & 110 & -- & -- & -- & -- & -- & -- & -- & -- & -- & -- & -- \\
\hline 370 & 8.8 & 110 & .2 & 32 & 640 & 602 & -- & - & -- & -- & -- & 17 & 1.1 \\
\hline-- & .2 & 110 & -- & -- & -- & -- & -- & -- & -- & -- & $\cdots$ & -- & -- \\
\hline-- & $<.2$ & 97 & -- & -- & -- & -- & -- & -- & -- & -- & -- & 17 & 1.1 \\
\hline-- & 4.8 & 79 & -- & -- & -- & -- & -- & -- & -- & -- & -- & -- & -- \\
\hline-- & 2.4 & 50 & -- & -- & -- & -- & -- & -- & -- & -- & -- & 14 & .86 \\
\hline-- & 2.4 & 64 & -- & -- & -- & -- & -- & -- & -- & -- & -- & -- & -- \\
\hline-- & .4 & 46 & -- & -- & -- & -- & -- & -- & -- & -- & -- & -- & -- \\
\hline-- & .4 & 51 & - & -- & -- & -- & -- & - & -- & -- & -- & -- & -- \\
\hline-- & .2 & 40 & -- & -- & -- & -- & -- & -- & -- & -- & -- & -- & -- \\
\hline-- & .2 & 48 & -- & -- & -- & -- & -- & -- & -- & -- & -- & -- & -- \\
\hline-- & 9.4 & 43 & -- & -- & -- & -- & -- & -- & -- & -- & -- & 11 & .59 \\
\hline-- & .8 & 43 & -- & -- & -- & -- & -- & $\rightarrow-$ & -- & -- & -- & - & -- \\
\hline-- & .4 & 48 & -- & -- & -- & -- & -- & -- & -- & -- & -- & 15 & .87 \\
\hline-- & 1.0 & 46 & -- & -- & -- & - & -- & - & -- & -- & -- & 13 & .88 \\
\hline-- & .4 & 48 & -- & -- & -- & -- & -- & -- & -- & -- & -- & 15 & .68 \\
\hline-- & .4 & 46 & -- & -- & -- & -- & -- & -- & -- & -- & -- & 16 & .76 \\
\hline 370 & .6 & 47 & -- & -- & -- & -- & -- & $-\infty$ & -- & -- & - & 16 & 1.0 \\
\hline 730 & 5.2 & 41 & .3 & 39 & 846 & 830 & -- & $-\infty$ & -- & -- & -- & 7.8 & .59 \\
\hline-- & 3.2 & 24 & -- & -- & -- & -- & -- & -- & -- & -- & -- & 8.2 & -- \\
\hline 740 & 4.8 & 44 & .2 & 38 & -- & 832 & -- & $-\cdots$ & -- & -- & -- & 13 & .62 \\
\hline-- & 1.4 & 45 & -- & -- & -- & -- & -- & -- & -- & -- & -- & 13 & .66 \\
\hline-- & 3.4 & 45 & -- & -- & -- & -- & -- & -- & -- & -- & -- & 8.9 & .67 \\
\hline-- & $<1.0$ & 44 & -- & -- & -- & -- & -- & -- & -- & -- & -- & 13 & .67 \\
\hline-- & .6 & 45 & -- & -- & -- & -- & -- & -- & -- & -- & -- & 14 & .60 \\
\hline-- & 1.0 & 46 & -- & -- & -- & -- & -- & -- & -- & -- & -- & 13 & .65 \\
\hline-- & $<1.0$ & 46 & -- & -- & -- & -- & -- & -- & -- & - & -- & 14 & .60 \\
\hline 770 & 2.0 & 44 & .3 & 45 & 874 & 869 & .06 & 0.10 & .20 & 0.02 & .08 & 14 & -- \\
\hline 740 & $<1.0$ & 45 & .3 & 38 & 873 & 817 & -- & -- & -- & -- & -- & -- & .60 \\
\hline-- & .6 & 43 & -- & - & -- & -- & -- & - & -- & -- & -- & 12 & .55 \\
\hline-- & 4.0 & 42 & -- & -- & -- & -- & -- & -- & -- & -- & -- & 13 & .68 \\
\hline-- & .6 & 45 & -- & -- & -- & -- & -- & -- & --- & -- & -- & 13 & .72 \\
\hline 840 & 10 & 42 & .3 & 47 & -- & 903 & -- & -- & -- & -- & -- & -- & -- \\
\hline
\end{tabular}


Table 1. Summary of chemical and physical analyses of water from wells completed in the Red River alluvial aquifer, Louisiana, 1965-92--continued

\begin{tabular}{|c|c|c|c|c|c|c|c|c|c|c|c|c|c|}
\hline $\begin{array}{c}\text { Wel l } \\
\text { no. }\end{array}$ & Date & $\begin{array}{l}\text { Water } \\
\text { level } \\
\text { below } \\
\text { land } \\
\text { sur- } \\
\text { face } \\
\text { (ft) }\end{array}$ & $\begin{array}{l}\text { Depth } \\
\text { of } \\
\text { well, } \\
\text { total } \\
\text { (ft) }\end{array}$ & $\begin{array}{l}\text { Spe- } \\
\text { cific } \\
\text { con- } \\
\text { duct- } \\
\text { ance } \\
(\mu \mathrm{s} / \mathrm{cm})\end{array}$ & $\begin{array}{c}\mathrm{pH}, \\
\text { field } \\
\text { (stand- } \\
\text { ard } \\
\text { units) }\end{array}$ & $\begin{array}{l}\text { Temper- } \\
\text { ature of } \\
\text { water } \\
\left({ }^{\circ} \mathrm{C}\right)\end{array}$ & $\begin{array}{l}\text { Color } \\
\text { (plat- } \\
\text { inum- } \\
\text { cobalt } \\
\text { units) }\end{array}$ & $\begin{array}{l}\text { Hard- } \\
\text { ness, } \\
\text { total } \\
\text { (mg/L } \\
\text { as } \\
\mathrm{CaCO}_{3} \text { ) }\end{array}$ & $\begin{array}{l}\text { Hard- } \\
\text { ness, } \\
\text { noncarb } \\
\text { whole } \\
\text { water } \\
\text { total } \\
\mathrm{fleld} \\
(\mathrm{mg} / \mathrm{L} \text { as } \\
\left.\mathrm{CaCO}_{3}\right)\end{array}$ & $\begin{array}{l}\text { Calcium, } \\
\text { dis- } \\
\text { solved } \\
\text { (mg/L } \\
\text { as (a) }\end{array}$ & $\begin{array}{l}\text { Magne- } \\
\text { sium, } \\
\text { dis- } \\
\text { solved } \\
\text { (mg/L } \\
\text { as } \mathrm{Mg} \text { ) }\end{array}$ & $\begin{array}{l}\text { Sodium, } \\
\text { dis- } \\
\text { solved } \\
\text { (mg/L } \\
\text { as } \mathrm{Na} \text { ) }\end{array}$ & $\begin{array}{l}\text { Potas- } \\
\text { sium, } \\
\text { dis- } \\
\text { solved } \\
\text { (mg/L } \\
\text { as K) }\end{array}$ \\
\hline \multirow[t]{24}{*}{$A V-372 A$} & $04-28-77$ & 12.37 & 173 & -- & 6.9 & 20.0 & 30 & 700 & 0 & 180 & 62 & 39 & 7.3 \\
\hline & $09-15-77$ & 29.51 & 173 & -- & -- & -- & -- & 710 & -- & -- & -- & -- & -- \\
\hline & $03-27-78$ & 20.84 & 173 & -- & 6.7 & 20.0 & -- & 680 & -- & -- & -- & -- & -- \\
\hline & $09-22-78$ & 30.82 & 173 & 1,420 & -- & -- & -- & 720 & -- & - & -- & -- & -- \\
\hline & $05-10-79$ & 21.37 & 173 & -- & 7.0 & 20.5 & -- & 700 & -- & -- & -- & -- & -- \\
\hline & $11-29-79$ & 40.82 & 173 & 1,150 & -- & -- & -- & 570 & -- & -- & -- & -- & -- \\
\hline & $04-11-80$ & 32.05 & 173 & -- & -- & -- & -- & 540 & -- & -- & -- & -- & -- \\
\hline & $04-27-81$ & 46.67 & 173 & -- & -- & -- & -- & 400 & -- & -- & -- & -- & -- \\
\hline & $09-29-81$ & 46.54 & 173 & -- & -- & -- & -- & 420 & -- & -- & -- & -- & - \\
\hline & $04-20-82$ & 38.37 & 173 & -- & -- & -- & -- & 430 & -- & -- & -- & -- & -- \\
\hline & $09-20-82$ & 40.95 & 173 & -- & -- & -- & -- & 430 & -- & -- & -- & -- & -- \\
\hline & $04-18-83$ & 29.66 & 173 & -- & -- & -- & -- & 410 & -- & 100 & 39 & -- & -- \\
\hline & $09-23-83$ & 40.77 & 173 & -- & -- & -- & -- & 430 & -- & 110 & 37 & -- & -- \\
\hline & $03-21-84$ & 18.07 & 173 & -- & 7.0 & 20.5 & -- & 390 & -- & 100 & 35 & -- & -- \\
\hline & $10-24-84$ & 24.33 & 173 & -- & 6.9 & 22.0 & -- & 380 & -- & 96 & 35 & -- & -- \\
\hline & $03-14-85$ & 11.85 & 173 & -- & 6.9 & -- & -- & 400 & -- & 99 & 36 & -- & -- \\
\hline & $10-08-85$ & 26.73 & 173 & -- & 7.1 & 22.0 & -- & 430 & -- & 110 & 37 & -- & -- \\
\hline & $04-01-86$ & 18.99 & 173 & -- & 6.9 & 20.0 & -- & 410 & -- & 100 & 40 & -- & -- \\
\hline & $08-29-86$ & 23.80 & 173 & -- & 6.9 & 20.5 & -- & 380 & -- & 96 & 33 & -- & -- \\
\hline & $03-26-87$ & 8.43 & 173 & 800 & 7.0 & 20.0 & -- & 360 & -- & 90 & 33 & -- & -- \\
\hline & $10-13-87$ & 24.90 & 173 & -- & 7.0 & -- & 0 & 390 & -- & 100 & 33 & 38 & 4.8 \\
\hline & $04-19-89$ & 11.88 & 173 & 732 & 7.0 & 20.5 & 10 & 320 & 0 & 79 & 29 & 27 & 4.3 \\
\hline & $03-26-91$ & 14.12 & 173 & 658 & 7.0 & 21.0 & 5 & 260 & -- & 67 & 23 & 27 & 3.9 \\
\hline & $04-26-92$ & 17.12 & 173 & 645 & 6.9 & 21.5 & -- & 250 & -- & 63 & 22 & 29 & 4.1 \\
\hline \multirow[t]{27}{*}{$A V-381$} & $01-13-76$ & 21.13 & 150 & -- & 6.9 & -- & 5 & 220 & 0 & 67 & 14 & 100 & 2.8 \\
\hline & $04-08-76$ & 14.95 & 150 & - & 7.3 & 20.0 & -- & 220 & -- & -- & -- & -- & -- \\
\hline & $07-09-76$ & 17.90 & 150 & -- & 6.9 & -- & -- & 210 & -- & -- & -- & -- & -- \\
\hline & $12-09-76$ & 24.18 & 150 & -- & 7.2 & 20.0 & -- & 190 & -- & -- & -- & -- & -- \\
\hline & $03-29-77$ & 18.46 & 150 & -- & 7.2 & 20.0 & 0 & 200 & 0 & 55 & 15 & 120 & 3.1 \\
\hline & $09-16-77$ & 24.45 & 150 & -- & 7.2 & 20.0 & 5 & 190 & 0 & 52 & 14 & 110 & 2.7 \\
\hline & $03-28-78$ & 20.96 & 150 & -- & 6.7 & 20.5 & -- & 190 & -- & -- & -- & -- & -- \\
\hline & $09-22-78$ & 26.80 & 150 & -- & -- & -- & -- & 200 & -- & -- & -- & -- & -- \\
\hline & $03-26-79$ & 11.90 & 150 & -- & 7.2 & 20.0 & -- & 190 & -- & -- & -- & -- & -- \\
\hline & $11-27-79$ & 21.66 & 150 & -- & -- & 20.0 & -- & 210 & -- & - & -- & -- & -- \\
\hline & $04-10-80$ & 14.02 & 150 & -- & 7.0 & 20.5 & -- & 200 & -- & -- & -- & -- & - \\
\hline & $09-18-80$ & 25.05 & 150 & -- & 6.9 & 20.5 & -- & 200 & -- & -- & -- & -- & -- \\
\hline & $04-27-81$ & 26.75 & 150 & -- & 7.1 & 20.5 & -- & 200 & -- & -- & -- & -- & -- \\
\hline & $09-28-81$ & 26.24 & 150 & -- & 7.0 & 20.5 & -- & 200 & -- & -- & -- & -- & -- \\
\hline & $04-19-82$ & 22.28 & 150 & -- & 7.1 & 20.5 & -- & 210 & -- & -- & -- & -- & -- \\
\hline & $09-22-82$ & 25.88 & 150 & -- & 7.0 & 20.5 & -- & 210 & -- & -- & -- & -- & -- \\
\hline & $04-20-83$ & 15.90 & 150 & -- & 7.1 & 20.5 & -- & 220 & -- & 55 & 19 & -- & -- \\
\hline & $09-23-83$ & 25.45 & 150 & -- & 7.0 & 20.5 & -- & 250 & -- & 65 & 21 & -- & -- \\
\hline & $03-20-84$ & 13.59 & 150 & -- & 7.0 & 20.5 & -- & 320 & -- & 84 & 27 & -- & -- \\
\hline & $10-23-84$ & 20.88 & 150 & -- & 7.2 & 21.0 & -- & 210 & -- & 54 & 19 & -- & -- \\
\hline & $03-25-85$ & 10.95 & 150 & -- & 6.8 & 21.5 & -- & 230 & -- & 59 & 20 & -- & -- \\
\hline & $10-11-85$ & 23.67 & 150 & -- & 7.1 & 20.5 & -- & 260 & -- & 65 & 23 & -- & -- \\
\hline & $04-02-86$ & 17.64 & 150 & -- & 7.0 & 20.5 & -- & 280 & -- & 76 & 23 & -- & -- \\
\hline & $08-28-86$ & 18.39 & 150 & -- & 7.0 & 20.5 & -- & 230 & -- & 60 & 19 & -- & -- \\
\hline & $06-15-87$ & 13.66 & 150 & -- & 7.1 & 20.0 & -- & 240 & -- & 63 & 21 & -- & -- \\
\hline & $06-24-88$ & 18.01 & 150 & 960 & 6.8 & 20.5 & 5 & 320 & -- & 85 & 25 & 120 & 2.6 \\
\hline & $04-16-90$ & 4.92 & 150 & 938 & 7.2 & 20.0 & 0 & 330 & -- & 83 & 29 & 100 & 2.9 \\
\hline
\end{tabular}


Table 1. Summary of chemical and physical analyses of water from wells completed in the Red River alluvial aquifer, Louisiana, 1965-92--continued

\begin{tabular}{|c|c|c|c|c|c|c|c|c|c|c|c|c|c|}
\hline $\begin{array}{l}\text { Alkalin- } \\
\text { ity, as } \\
\text { calcium } \\
\text { carbonate, } \\
\text { field } \\
(\mathrm{mg} / \mathrm{L} \text { as } \\
\left.\mathrm{CaCO}_{3}\right)\end{array}$ & $\begin{array}{l}\text { Sulfate, } \\
\text { dis- } \\
\text { solved } \\
\langle\mathrm{mg} / \mathrm{L} \\
\left.\text { as } \mathrm{SO}_{4}\right\rangle\end{array}$ & $\begin{array}{l}\text { Chlo- } \\
\text { ride, } \\
\text { dis- } \\
\text { solved } \\
(\mathrm{mg} / \mathrm{L} \\
\text { as Cl) }\end{array}$ & $\begin{array}{l}\text { Fluo- } \\
\text { ride, } \\
\text { dis- } \\
\text { solved } \\
\text { (mg/L } \\
\text { as F) }\end{array}$ & $\begin{array}{l}\text { Silica, } \\
\text { dis- } \\
\text { solved } \\
\text { (mg/L } \\
\text { as } \\
\mathrm{SiO}_{2} \text { ) }\end{array}$ & $\begin{array}{l}\text { Solids, } \\
\text { residue } \\
\text { at } \\
100{ }^{\circ} \mathrm{C} \text {, } \\
\text { dis- } \\
\text { solved } \\
\text { (mg/L) }\end{array}$ & $\begin{array}{l}\text { Solids, } \\
\text { sum of } \\
\text { constit- } \\
\text { uents, } \\
\text { dis- } \\
\text { solved } \\
\text { (mg/L) }\end{array}$ & $\begin{array}{l}\text { Nitro- } \\
\text { gen, } \\
\text { nitrite } \\
\text { dis- } \\
\text { solved } \\
\text { (mg/L } \\
\text { as N) }\end{array}$ & $\begin{array}{c}\text { Nitro- } \\
\text { gen, } \\
\text { nitrate } \\
\text { total } \\
\text { (mg/L } \\
\text { as } \mathrm{NO}_{3} \text { ) }\end{array}$ & $\begin{array}{l}\text { Nitro- } \\
\text { gen, } \\
\text { nitrite } \\
\text { dis- } \\
\text { solved } \\
\text { (mg/L } \\
\left.\text { as } \mathrm{NO}_{2}\right)\end{array}$ & $\begin{array}{l}\text { Nitro- } \\
\text { gen, } \\
\text { nitrate } \\
\text { dis- } \\
\text { solved } \\
\text { (mg/L } \\
\text { as N) }\end{array}$ & $\begin{array}{l}\text { Nitro- } \\
\text { gen, } \\
\mathrm{NO}_{2}+\mathrm{NO}_{3} \\
\text { dis- } \\
\text { solved } \\
\text { (mg/L } \\
\text { as N) }\end{array}$ & $\begin{array}{l}\text { Iron, } \\
\text { dis- } \\
\text { solved } \\
\text { (mg/L } \\
\text { as Fe) }\end{array}$ & $\begin{array}{l}\text { Manga- } \\
\text { nese, } \\
\text { dis- } \\
\text { solved } \\
\text { (mg/L } \\
\text { as } M n \text { ) }\end{array}$ \\
\hline 770 & 6.8 & 42 & 0.1 & 35 & 861 & 846 & -- & 0.0 & -- & -- & -- & 13 & 0.60 \\
\hline-- & 12 & 40 & -- & -- & -- & -- & -- & -- & - & -- & -- & - & - \\
\hline-- & 6.8 & 40 & -- & -- & -- & -- & -- & -- & -- & -- & -- & 12 & .61 \\
\hline-- & .4 & 41 & -- & -- & -- & -- & -- & -- & -- & -- & -- & -- & -- \\
\hline-- & .6 & 60 & -- & -- & -- & -- & -- & -- & -- & -- & -- & 12 & .73 \\
\hline-- & 31 & 38 & -- & -- & -- & -- & -- & - & -- & -- & -- & -- & - \\
\hline-- & 17 & 34 & -- & -- & -- & -- & -- & -- & -- & -- & -- & -- & -- \\
\hline-- & 14 & 28 & -- & -- & -- & -- & -- & -- & -- & -- & -- & -- & - \\
\hline-- & 14 & 30 & -- & -- & -- & -- & -- & -- & -- & -- & -- & -- & -- \\
\hline-- & 14 & 37 & -- & -- & -- & -- & -- & -- & -- & -- & -- & -- & -- \\
\hline-- & 35 & 36 & -- & -- & -- & -- & -- & -- & -- & -- & - & -- & - \\
\hline-- & 8.2 & 34 & -- & -- & -- & -- & -- & -- & -- & -- & -- & -- & -- \\
\hline-- & 6.0 & 32 & -- & -- & -- & - & -- & -- & -- & -- & -- & -- & .34 \\
\hline-- & 1.2 & 30 & -- & -- & -- & -- & -- & -- & -- & -- & -- & 7.7 & .34 \\
\hline-- & 2.6 & 29 & -- & -- & -- & -- & -- & -- & -- & -- & -- & 7.6 & .40 \\
\hline-- & 4.0 & 28 & -- & -- & -- & -- & -- & -- & -- & -- & -- & 7.8 & .39 \\
\hline-- & 2.6 & 48 & -- & -- & -- & -- & -- & -- & -- & -- & -- & 7.1 & .44 \\
\hline-- & 1.2 & 30 & -- & -- & -- & -- & -- & -- & -- & -- & -- & 7.8 & .40 \\
\hline-- & .6 & 27 & -- & -- & -- & -- & -- & -- & -- & -- & -- & 7.5 & .33 \\
\hline 410 & .6 & 22 & -- & -- & -- & -- & -- & -- & -- & -- & -- & 6.4 & .52 \\
\hline 400 & 5.0 & 21 & .1 & 46 & 450 & 494 & -- & -- & -- & -- & 1.2 & 6.0 & .68 \\
\hline 321 & 14 & 34 & .2 & 45 & 382 & 432 & $<0.01$ & -- & -- & - & .48 & 4.8 & .37 \\
\hline 232 & 20 & 60 & .3 & 44 & 417 & 389 & $<.01$ & -- & -- & -- & .02 & 4.5 & .25 \\
\hline 186 & 39 & 68 & .3 & 44 & 396 & 485 & $<.10$ & + & -- & $-\infty$ & .02 & 4.3 & .23 \\
\hline 360 & 7.8 & 55 & .5 & 32 & 508 & 497 & -- & -- & -- & -- & -- & 2.3 & .18 \\
\hline-- & 28 & 55 & -- & -- & -- & -- & -- & -- & -- & -- & -- & 2.3 & .14 \\
\hline-- & 7.8 & 57 & -- & -- & -- & -- & -- & -- & -- & -- & -- & 2.2 & .14 \\
\hline-- & 4.4 & 70 & -- & -- & -- & -- & -- & -- & -- & -- & -- & 1.9 & .08 \\
\hline 370 & 8.2 & 62 & .6 & 41 & 502 & 528 & -- & -- & -- & -- & -- & 2.3 & .12 \\
\hline 340 & 6.6 & 64 & .6 & 32 & 485 & 491 & -- & -- & -- & -- & - & 2.1 & .12 \\
\hline-- & 6.6 & 63 & -- & -- & -- & -- & -- & -- & -- & -- & -- & 2.1 & .14 \\
\hline-- & 4.4 & 66 & -- & -- & -- & -- & -- & -- & -- & -- & -- & -- & -- \\
\hline-- & 6.6 & 65 & -- & -- & -- & -- & -- & -- & -- & -- & -- & 2.3 & .14 \\
\hline-- & 7.4 & 64 & -- & -- & -- & -- & -- & -- & -- & -- & -- & 2.2 & .13 \\
\hline-- & 6.8 & 64 & -- & -- & -- & -- & -- & -- & -- & -- & -- & 2.2 & .12 \\
\hline-- & 9.0 & 62 & - & - & -- & -- & -- & -- & - & -- & -- & 2.1 & .13 \\
\hline-- & 6.4 & 63 & -- & -- & -- & -- & -- & -- & -- & -- & -- & 2.4 & .15 \\
\hline-- & 6.0 & 64 & -- & -- & -- & -- & -- & -- & -- & -- & -- & 2.3 & .13 \\
\hline-- & 4.2 & 66 & -- & -- & -- & -- & -- & -- & -- & -- & -- & 2.6 & .17 \\
\hline-- & 7.4 & 66 & -- & -- & -- & -- & -- & -- & -- & -- & -- & 2.3 & .20 \\
\hline-- & 7.0 & 61 & -- & -- & -- & -- & -- & -- & -- & -- & -- & 2.5 & .17 \\
\hline- & 9.8 & 56 & -- & -- & -- & -- & -- & -- & -- & -- & -- & 2.7 & .14 \\
\hline-- & 13 & 49 & -- & -- & -- & -- & -- & -- & -- & -- & -- & 4.9 & .19 \\
\hline-- & 6.2 & 63 & -- & -- & -- & -- & -- & - & -- & -- & -- & 2.6 & .16 \\
\hline-- & 7.2 & 60 & -- & -- & -- & -- & -- & -- & -- & -- & -- & 2.1 & .13 \\
\hline-- & 12 & 56 & -- & -- & -- & -- & -- & -- & -- & -- & -- & 2.6 & .15 \\
\hline-- & 7.6 & 62 & -- & -- & -- & -- & -- & -- & -- & -- & -- & 2.7 & .24 \\
\hline-- & 8.2 & 57 & -- & -- & -- & -- & -- & -- & -- & -- & -- & 2.7 & .13 \\
\hline 398 & 6.6 & 58 & -- & -- & -- & -- & -- & -- & -- & -- & -- & 2.6 & .15 \\
\hline 466 & 14 & 46 & .4 & 34 & 553 & 610 & $<.01$ & -- & -- & -- & $<.02$ & 3.5 & .23 \\
\hline 455 & 11 & 61 & .6 & 35 & 560 & 599 & $<.01$ & -- & -- & -- & $<.02$ & 3.6 & .18 \\
\hline
\end{tabular}


Table 1. Summary of chemical and physical analyses of water from wells completed in the Red River alluvial aquifer, Louisiana, 1965-92--continued

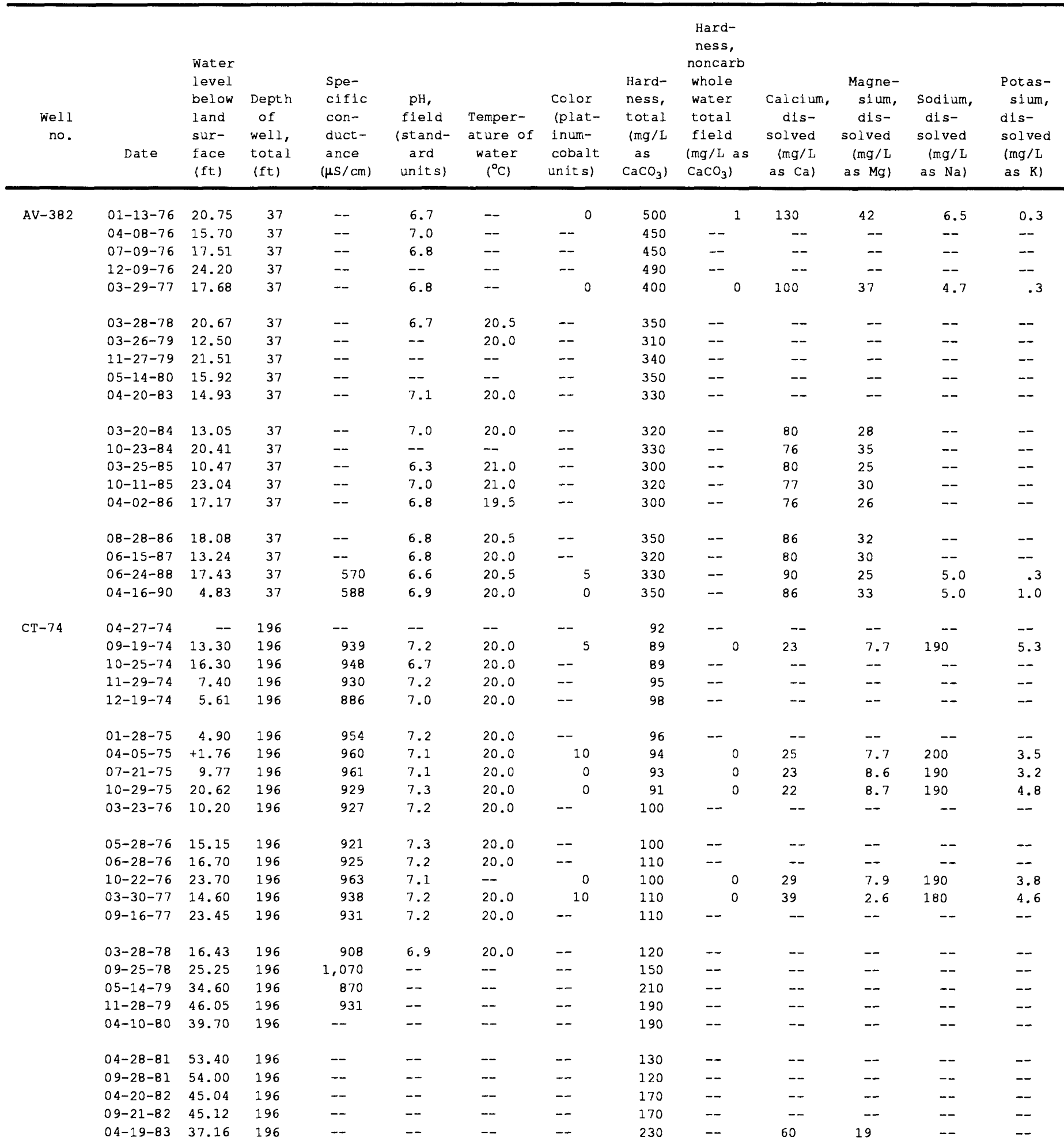


Table 1. Summary of chemical and physical analyses of water from wells completed in the Red River alluvial aquifer, Louisiana, 1965-92--continued

\begin{tabular}{|c|c|c|c|c|c|c|c|c|c|c|c|c|c|}
\hline $\begin{array}{l}\text { Alkalin- } \\
\text { ity, as } \\
\text { calcium } \\
\text { carbonate, } \\
\text { field } \\
(\mathrm{mg} / \mathrm{L} \text { as } \\
\mathrm{CaCO})_{3}\end{array}$ & $\begin{array}{l}\text { sulfate, } \\
\text { dis- } \\
\text { solved } \\
(\mathrm{mg} / \mathrm{L} \\
\left.\text { as } \mathrm{SO}_{4}\right)\end{array}$ & $\begin{array}{l}\text { Chlo- } \\
\text { ride, } \\
\text { dis- } \\
\text { solved } \\
\text { (mg/L } \\
\text { as Cl) }\end{array}$ & $\begin{array}{l}\text { Fluo- } \\
\text { ride, } \\
\text { dis- } \\
\text { solved } \\
\text { (mg/L } \\
\text { as F) }\end{array}$ & $\begin{array}{l}\text { silica, } \\
\text { dis- } \\
\text { solved } \\
\text { (mg/L } \\
\text { as } \\
\mathrm{SiO}_{2} \text { ) }\end{array}$ & $\begin{array}{l}\text { Solids, } \\
\text { residue } \\
\text { at } \\
100{ }^{\circ} \mathrm{C} \text {, } \\
\text { dis- } \\
\text { solved } \\
(\mathrm{mg} / \mathrm{L})\end{array}$ & $\begin{array}{l}\text { Solids, } \\
\text { sum of } \\
\text { constit- } \\
\text { uents, } \\
\text { dis- } \\
\text { solved } \\
\text { (mg/L) }\end{array}$ & $\begin{array}{l}\text { Nitro- } \\
\text { gen, } \\
\text { nitrite } \\
\text { dis- } \\
\text { solved } \\
\text { (mg/L } \\
\text { as N) }\end{array}$ & $\begin{array}{c}\text { Nitro- } \\
\text { gen, } \\
\text { nitrate } \\
\text { total } \\
(\mathrm{mg} / \mathrm{L} \\
\left.\text { as } \mathrm{NO}_{3}\right)\end{array}$ & $\begin{array}{l}\text { Nitro- } \\
\text { gen, } \\
\text { nitrite } \\
\text { dis- } \\
\text { solved } \\
\text { (mg/L } \\
\left.\text { as } \mathrm{NO}_{2}\right)\end{array}$ & $\begin{array}{c}\text { Nitro- } \\
\text { gen, } \\
\text { nitrate } \\
\text { dis- } \\
\text { solved } \\
\text { (mg/L } \\
\text { as N) }\end{array}$ & $\begin{array}{l}\text { Nitro- } \\
\text { gen, } \\
\mathrm{NO}_{2}+\mathrm{NO}_{3} \\
\text { dis- } \\
\text { solved } \\
\text { (mg/L } \\
\text { as N) }\end{array}$ & $\begin{array}{l}\text { Iron, } \\
\text { dis- } \\
\text { solved } \\
\text { (mg/L } \\
\text { as Fe) }\end{array}$ & $\begin{array}{l}\text { Manga- } \\
\text { nese, } \\
\text { dis- } \\
\text { solved } \\
\text { (mg/L } \\
\text { as Mn) }\end{array}$ \\
\hline 490 & 10 & 3.6 & 1.0 & 25 & 499 & 510 & -- & -- & -- & -- & -- & 0.14 & 0.38 \\
\hline-- & 15 & 3.8 & -- & -- & -- & -- & -- & -- & -- & -- & -- & .33 & .16 \\
\hline-- & 10 & 3.0 & -- & -- & -- & -- & -- & -- & -- & -- & -- & .12 & .14 \\
\hline-- & 9.6 & 4.2 & -- & -- & -- & -- & -- & - & -- & -- & -- & - & .26 \\
\hline 400 & 11 & 1.8 & .3 & 29 & 404 & 426 & -- & -- & -- & -- & -- & .17 & .25 \\
\hline-- & 9.4 & 2.0 & -- & -- & -- & -- & -- & -- & -- & -- & -- & .09 & .35 \\
\hline-- & 8.8 & 1.8 & -- & -- & -- & -- & -- & -- & -- & -- & -- & .24 & .30 \\
\hline-- & 10 & 1.0 & -- & -- & -- & -- & -- & - & -- & -- & -- & -- & -- \\
\hline-- & 8.6 & 1.2 & -- & -- & -- & -- & -- & -- & -- & -- & -- & .13 & .37 \\
\hline-- & 8.4 & 1.8 & -- & -- & -- & -- & -- & -- & -- & -- & -- & .22 & .18 \\
\hline- & 8.5 & 4.4 & -- & -- & -- & -- & -- & -- & -- & -- & -- & .85 & .14 \\
\hline-- & 6.6 & 4.0 & -- & -- & -- & -- & -- & -- & -- & -- & -- & .92 & .24 \\
\hline-- & 10 & 4.5 & -- & -- & -- & -- & -- & -- & -- & -- & -- & 1.2 & .24 \\
\hline-- & 9.4 & 7.0 & -- & -- & -- & -- & -- & -- & -- & -- & -- & 2.4 & .16 \\
\hline-- & 6.0 & 4.2 & -- & -- & -- & -- & -- & -- & -- & -- & -- & 2.3 & .34 \\
\hline-- & 8.2 & 3.6 & -- & -- & -- & - & -- & -- & -- & -- & -- & 1.0 & .18 \\
\hline 308 & 7.6 & 4.7 & -- & -- & -- & -- & -- & -- & -- & -- & -- & 3.0 & .30 \\
\hline 318 & 12 & 5.5 & .2 & 28 & 201 & 361 & -- & -- & -- & $<0.01$ & 0.41 & 2.7 & .26 \\
\hline 325 & 12 & 5.5 & .4 & 27 & 349 & 369 & 0.02 & -- & 0.07 & .66 & .68 & 1.2 & .26 \\
\hline-- & -- & 48 & -- & -- & -- & -- & -- & -- & -- & -- & -- & -- & -- \\
\hline 440 & 2.2 & 45 & .5 & 32 & 578 & 571 & -- & 0.35 & - & -- & -- & .19 & .09 \\
\hline-- & 2.2 & 46 & -- & -- & -- & -- & -- & -- & -- & -- & -- & .25 & .08 \\
\hline-- & 4.0 & 46 & -- & -- & -- & - & -- & -- & -- & -- & -- & .28 & .10 \\
\hline-- & .6 & 47 & -- & -- & -- & -- & -- & -- & -- & -- & -- & .31 & .10 \\
\hline-- & .8 & 45 & -- & -- & -- & -- & -- & -- & -- & -- & -- & .41 & .14 \\
\hline 450 & .3 & 47 & .6 & 34 & 597 & 596 & .01 & -- & .03 & 1.69 & 1.7 & .30 & .10 \\
\hline 440 & $<1.0$ & 48 & .5 & 33 & 597 & 568 & -- & .05 & -- & -- & -- & .31 & .09 \\
\hline 450 & .8 & 44 & .4 & 31 & 578 & 572 & -- & .27 & -- & -- & -- & .33 & .12 \\
\hline-- & 6.2 & 45 & -- & -- & -- & -- & -- & -- & -- & -- & -- & .43 & .13 \\
\hline-- & .6 & 44 & -- & -- & -- & -- & -- & -- & -- & -- & -- & .42 & .12 \\
\hline-- & .2 & 44 & -- & -- & -- & -- & -- & -- & -- & -- & -- & .44 & .19 \\
\hline 430 & -- & 45 & .1 & 35 & 585 & -- & -- & 4.4 & -- & -- & -- & .33 & .12 \\
\hline 460 & 1.8 & 42 & .3 & 40 & 577 & 584 & -- & 1.2 & -- & -- & -- & .54 & .14 \\
\hline-- & $<1.0$ & 45 & -- & -- & -- & -- & -- & -- & -- & -- & -- & .66 & .17 \\
\hline-- & .8 & 43 & -- & -- & -- & -- & -- & -- & -- & -- & -- & .75 & .20 \\
\hline-- & 6.4 & 43 & -- & -- & -- & -- & -- & -- & -- & -- & -- & -- & .26 \\
\hline-- & .4 & 68 & -- & -- & -- & - & -- & -- & -- & -- & -- & -- & .25 \\
\hline-- & .6 & 55 & -- & -- & -- & -- & -- & -- & -- & -- & -- & -- & .20 \\
\hline-- & 13 & 68 & -- & -- & -- & -- & -- & -- & -- & -- & -- & -- & .22 \\
\hline-- & 5.0 & 68 & -- & -- & -- & -- & -- & -- & -- & -- & -- & -- & .16 \\
\hline-- & 3.8 & 57 & -- & -- & -- & -- & -- & -- & -- & -- & -- & -- & .12 \\
\hline-- & 24 & 62 & -- & -- & -- & -- & -- & -- & -- & -- & -- & -- & .20 \\
\hline-- & 20 & 64 & -- & -- & -- & -- & -- & -- & -- & -- & -- & -- & .28 \\
\hline-- & .4 & 58 & -- & -- & -- & -- & -- & -- & -- & -- & -- & -- & .32 \\
\hline
\end{tabular}


Table 1. Summary of chemical and physical analyses of water from wells completed in the Red River alluvial aquifer, Louisiana, 1965-92--continued

\begin{tabular}{|c|c|c|c|c|c|c|c|c|c|c|c|c|c|}
\hline $\begin{array}{c}\text { Well } \\
\text { no. }\end{array}$ & Date & $\begin{array}{l}\text { Water } \\
\text { level } \\
\text { below } \\
\text { land } \\
\text { sur- } \\
\text { face } \\
\text { (ft) }\end{array}$ & $\begin{array}{l}\text { Depth } \\
\text { of } \\
\text { well, } \\
\text { total } \\
\text { (ft) }\end{array}$ & $\begin{array}{l}\text { Spe- } \\
\text { cific } \\
\text { con- } \\
\text { duct- } \\
\text { ance } \\
(\mu \mathrm{S} / \mathrm{cm})\end{array}$ & $\begin{array}{l}\mathrm{pH}, \\
\text { field } \\
\text { (stand- } \\
\text { ard } \\
\text { units) }\end{array}$ & $\begin{array}{l}\text { Temper- } \\
\text { ature of } \\
\text { water } \\
\left({ }^{\circ} \mathrm{C}\right)\end{array}$ & $\begin{array}{l}\text { Color } \\
\text { (plat- } \\
\text { inum- } \\
\text { cobalt } \\
\text { units) }\end{array}$ & $\begin{array}{l}\text { Hard- } \\
\text { ness, } \\
\text { total } \\
\text { (mg/L } \\
\text { as } \\
\mathrm{CaCO}_{3} \text { ) }\end{array}$ & $\begin{array}{l}\text { Hard- } \\
\text { ness, } \\
\text { noncarb } \\
\text { whole } \\
\text { water } \\
\text { total } \\
\text { field } \\
(\mathrm{mg} / \mathrm{L} \text { as } \\
\left.\mathrm{CaCO}_{3}\right)\end{array}$ & $\begin{array}{c}\text { Calcium, } \\
\text { dis- } \\
\text { solved } \\
\text { (mg/L } \\
\text { as Ca) }\end{array}$ & $\begin{array}{l}\text { Magne- } \\
\text { sium, } \\
\text { dis- } \\
\text { solved } \\
\text { (mg/L } \\
\text { as Mg) }\end{array}$ & $\begin{array}{l}\text { Sodium, } \\
\text { dis- } \\
\text { solved } \\
\text { (mg/L } \\
\text { as } \mathrm{Na} \text { ) }\end{array}$ & $\begin{array}{l}\text { Potas- } \\
\text { sium, } \\
\text { dis- } \\
\text { solved } \\
\text { (mg/L } \\
\text { as K) }\end{array}$ \\
\hline \multirow[t]{12}{*}{$\mathrm{CT}-74$} & $09-26-83$ & 45.38 & 196 & -- & -- & -- & -- & 230 & -- & 56 & 21 & -- & -- \\
\hline & $03-20-84$ & 14.71 & 196 & -- & 7.1 & 20.0 & -- & 230 & -- & 59 & 20 & -- & -- \\
\hline & $10-23-84$ & 21.18 & 196 & -- & 7.3 & 20.0 & -- & 240 & - & 58 & 22 & -- & -- \\
\hline & $03-25-85$ & 7.98 & 196 & -- & 7.1 & 21.5 & -- & 250 & -- & 64 & 22 & -- & -- \\
\hline & $10-11-85$ & 23.96 & 196 & -- & 7.1 & 20.5 & -- & 260 & -- & 62 & 26 & -- & -- \\
\hline & $04-02-86$ & 15.10 & 196 & -- & 7.3 & 20.0 & -- & 290 & -- & 70 & 28 & -- & -- \\
\hline & $08-28-86$ & 20.54 & 196 & -- & 7.1 & 20.5 & -- & 290 & -- & 71 & 28 & -- & -- \\
\hline & $06-15-87$ & 13.34 & 196 & -- & 7.2 & 20.0 & -- & 330 & -- & 85 & 28 & -- & -- \\
\hline & $06-23-88$ & 20.40 & 196 & 1,290 & 7.2 & 21.0 & 0 & 300 & -- & 80 & 25 & 170 & 4.7 \\
\hline & $04-18-89$ & 8.30 & 196 & 1,320 & 7.2 & 21.0 & 5 & 290 & -- & 70 & 28 & 170 & 4.5 \\
\hline & $03-26-91$ & 10.56 & 196 & 1,330 & 7.2 & 21.0 & 5 & 281 & -- & 73 & 24 & 190 & 5.3 \\
\hline & $04-28-92$ & 13.37 & 196 & 1,300 & 7.2 & 21.5 & -- & 270 & -- & 72 & 22 & 190 & 5.0 \\
\hline \multirow[t]{36}{*}{$\mathrm{CT}-75$} & $04-21-70$ & -- & 107 & 741 & -- & -- & 7 & 340 & 0 & 96 & 25 & 27 & 6.0 \\
\hline & $10-18-72$ & -- & 107 & 690 & -- & -- & -- & 330 & - & 91 & 24 & -- & -- \\
\hline & $11-28-72$ & -- & 107 & 751 & -- & -- & -- & 320 & -- & 91 & 23 & -- & -- \\
\hline & $12-19-72$ & -- & 107 & 750 & -- & -- & -- & 320 & -- & 92 & 23 & -- & -- \\
\hline & $10-01-73$ & -- & 107 & -- & -- & -- & -- & 320 & -- & -- & -- & -- & -- \\
\hline & $12-03-73$ & 5.77 & 107 & 752 & -- & 20.0 & -- & 450 & -- & -- & - & -- & -- \\
\hline & $09-23-74$ & 8.08 & 107 & 755 & 6.9 & 19.5 & 5 & 340 & 0 & 92 & 26 & 32 & 7.1 \\
\hline & $10-25-74$ & 9.47 & 107 & 746 & -- & 19.5 & -- & 340 & -- & -- & -- & -- & -- \\
\hline & $11-29-74$ & 7.68 & 107 & 657 & 6.8 & 20.0 & -- & 340 & -- & -- & -- & -- & -- \\
\hline & $12-19-74$ & 6.49 & 107 & 743 & 6.9 & 20.0 & -- & 340 & -- & -- & - & -- & -- \\
\hline & $01-28-75$ & 3.98 & 107 & 748 & 7.1 & 20.0 & -- & 330 & -- & -- & -- & -- & -- \\
\hline & $07-21-75$ & 2.45 & 107 & 756 & 6.9 & 19.5 & 0 & 330 & 0 & 98 & 20 & 29 & 5.7 \\
\hline & $10-29-75$ & 9.08 & 107 & 725 & 7.1 & 20.0 & 0 & 330 & 0 & 86 & 28 & 30 & 6.8 \\
\hline & $03-23-76$ & 5.65 & 107 & 745 & 6.8 & 20.0 & -- & 340 & -- & - & -- & -- & -- \\
\hline & $06-29-76$ & 8.10 & 107 & 749 & 6.6 & 20.0 & -- & 340 & -- & -- & -- & -- & -- \\
\hline & $10-26-76$ & 13.21 & 107 & 751 & 7.0 & 20.0 & 0 & 330 & 0 & 92 & 24 & 29 & 6.4 \\
\hline & $03-30-77$ & 9.70 & 107 & 730 & 6.9 & 20.0 & 10 & 320 & 0 & 100 & 18 & 30 & 6.9 \\
\hline & $09-16-77$ & 13.25 & 107 & 750 & 7.0 & 20.0 & -- & 340 & -- & -- & -- & -- & -- \\
\hline & $03-28-78$ & 10.43 & 107 & 714 & 7.0 & 20.0 & -- & 310 & -- & -- & -- & -- & -- \\
\hline & $09-25-78$ & 14.10 & 107 & 863 & 7.0 & 20.0 & -- & 320 & -- & -- & -- & -- & -- \\
\hline & $11-28-79$ & 14.21 & 107 & 714 & -- & 20.0 & -- & 320 & -- & -- & -- & -- & -- \\
\hline & $04-10-80$ & 9.40 & 107 & -- & 7.0 & 20.0 & -- & 320 & -- & -- & -- & -- & -- \\
\hline & $09-19-80$ & 16.27 & 107 & -- & 6.9 & 20.0 & -- & 320 & -- & -- & -- & -- & -- \\
\hline & $04-28-81$ & 18.37 & 107 & -- & 7.0 & 20.0 & -- & 310 & -- & -- & -- & -- & -- \\
\hline & $09-28-81$ & 18.76 & 107 & -- & 6.9 & 20.0 & -- & 310 & -- & -- & -- & -- & -- \\
\hline & $04-19-82$ & 16.52 & 107 & -- & 7.0 & 20.0 & -- & 320 & -- & -- & -- & -- & -- \\
\hline & $09-21-82$ & 18.17 & 107 & -- & 6.9 & 20.0 & -- & 310 & -- & -- & -- & -- & -- \\
\hline & $04-19-83$ & 9.82 & 107 & -- & 6.8 & 20.0 & -- & 320 & -- & 88 & 25 & - & -- \\
\hline & $03-25-85$ & 7.32 & 107 & -- & 6.7 & 21.0 & -- & 330 & -- & 91 & 26 & -- & -- \\
\hline & $10-11-85$ & 14.77 & 107 & -- & 7.1 & 20.0 & -- & 320 & -- & 85 & 25 & -- & -- \\
\hline & $04-02-86$ & 11.08 & 107 & -- & 7.2 & 20.0 & -- & 360 & -- & 100 & 27 & -- & -- \\
\hline & $08-28-86$ & 16.33 & 107 & -- & 7.1 & 20.5 & -- & 340 & -- & 94 & 25 & -- & -- \\
\hline & $06-15-87$ & 10.57 & 107 & -- & 7.1 & 20.0 & -- & 340 & -- & 95 & 25 & -- & -- \\
\hline & $06-23-88$ & 15.42 & 107 & 740 & 7.0 & 21.0 & 0 & 350 & -- & 100 & 24 & 32 & 5.8 \\
\hline & $04-19-89$ & 7.96 & 107 & 738 & 7.2 & 20.5 & 5 & 310 & -- & 86 & 23 & 30 & 6.6 \\
\hline & $04-12-90$ & 6.80 & 107 & 766 & 7.2 & 20.0 & 0 & 330 & -- & 94 & 22 & 30 & 6.7 \\
\hline
\end{tabular}


Table 1. Summary of chemical and physical analyses of water from wells completed in the Red River alluvial aquifer, Louisiana, 1965-92--continued

\begin{tabular}{|c|c|c|c|c|c|c|c|c|c|c|c|c|c|}
\hline $\begin{array}{l}\text { Alkalin- } \\
\text { ity, as } \\
\text { calclum } \\
\text { carbonate, } \\
\text { field } \\
\left(\mathrm{mg}_{\mathrm{L}} \mathrm{L} \text { as }\right. \\
\left.\mathrm{CaCO}_{3}\right)\end{array}$ & $\begin{array}{l}\text { Sulfate, } \\
\text { dis- } \\
\text { solved } \\
\text { (mg/L } \\
\left.\text { as } \mathrm{SO}_{4}\right)\end{array}$ & $\begin{array}{l}\text { Chlo- } \\
\text { ride, } \\
\text { dis- } \\
\text { solved } \\
\text { (mg/L } \\
\text { as } \mathrm{Cl} \text { ) }\end{array}$ & $\begin{array}{l}\text { Fluo- } \\
\text { ride, } \\
\text { dis- } \\
\text { solved } \\
\langle\mathrm{mg} / \mathrm{L} \\
\text { as F }\end{array}$ & $\begin{array}{l}\text { Silica, } \\
\text { dis- } \\
\text { solved } \\
\text { (mg/L } \\
\text { as } \\
\mathrm{SiO}_{2} \text { ) }\end{array}$ & $\begin{array}{l}\text { Solids, } \\
\text { residue } \\
\text { at } \\
100^{\circ} \mathrm{C} \text {, } \\
\text { dis- } \\
\text { solved } \\
(\mathrm{mg} / \mathrm{L})\end{array}$ & $\begin{array}{l}\text { Solids, } \\
\text { sum of } \\
\text { constit- } \\
\text { uents, } \\
\text { dis- } \\
\text { solved } \\
\text { (mg/L) }\end{array}$ & $\begin{array}{l}\text { Nitro- } \\
\text { gen, } \\
\text { nitrite } \\
\text { dis- } \\
\text { solved } \\
\text { (mg/L } \\
\text { as N) }\end{array}$ & $\begin{array}{l}\text { Nitro- } \\
\text { gen, } \\
\text { nitrate } \\
\text { total } \\
(\mathrm{mg} / \mathrm{L} \\
\left.\text { as } \mathrm{NO}_{3}\right)\end{array}$ & $\begin{array}{l}\text { Nitro- } \\
\text { gen, } \\
\text { nitrite } \\
\text { dis- } \\
\text { solved } \\
\text { (mg/L } \\
\text { as } \mathrm{NO}_{2} \text { ) }\end{array}$ & $\begin{array}{l}\text { Nitro- } \\
\text { gen, } \\
\text { nitrate } \\
\text { dis- } \\
\text { solved } \\
\text { (mg/L } \\
\text { as } N \text { ) }\end{array}$ & $\begin{array}{l}\text { Nitro- } \\
\text { gen, } \\
\mathrm{NO}_{2}+\mathrm{NO}_{3} \\
\text { dis- } \\
\text { solved } \\
\text { (mg/L } \\
\text { as } \mathrm{N} \text { ) }\end{array}$ & $\begin{array}{l}\text { Iron, } \\
\text { dis- } \\
\text { solved } \\
\text { (mg/L } \\
\text { as Fe) }\end{array}$ & $\begin{array}{l}\text { Manga- } \\
\text { nese, } \\
\text { dis- } \\
\text { solved } \\
\text { (mg/L } \\
\text { as } \mathrm{Mn} \text { ) }\end{array}$ \\
\hline- & 1.6 & 58 & -- & -- & -- & -- & -- & -- & -- & -- & -- & -- & 0.21 \\
\hline-- & .3 & 66 & - & -- & -- & -- & -- & -- & -- & -- & -- & 1.2 & .24 \\
\hline -- & .2 & 77 & -- & -- & -- & -- & -- & -- & - & -- & -- & 1.3 & .31 \\
\hline-- & .2 & 86 & -- & -- & -- & - & -- & -- & -- & -- & -- & 1.2 & .28 \\
\hline-- & 1.6 & 110 & -- & -- & -- & -- & -- & -- & -- & -- & -- & 1.3 & .40 \\
\hline-- & .4 & 130 & -- & -- & -- & -- & -- & -- & -- & -- & -- & 1.4 & .48 \\
\hline-- & 2.2 & 130 & -- & -- & -- & -- & -- & -- & -- & -- & -- & 1.4 & .29 \\
\hline 472 & 6.0 & 130 & -- & -- & -- & -- & -- & -- & -- & -- & -- & 1.5 & .40 \\
\hline 486 & 16 & 130 & 0.2 & 35 & 743 & 755 & $<0.01$ & -- & -- & -- & $<0.02$ & 1.6 & .76 \\
\hline 509 & 8.2 & 130 & .4 & 35 & 745 & 753 & $<.01$ & -- & -- & -- & $<.02$ & 1.5 & .37 \\
\hline 523 & 1.2 & 130 & .3 & 34 & 763 & 774 & $<.01$ & -- & -- & -- & .02 & 1.5 & .36 \\
\hline 523 & 2.8 & 130 & .3 & 33 & 780 & 770 & $<.01$ & -- & -- & -- & .02 & 1.3 & .27 \\
\hline 380 & .4 & 26 & .5 & 34 & 432 & 446 & -- & 0.0 & -- & -- & -- & 4.8 & .60 \\
\hline-- & -- & 28 & -- & -- & -- & $\cdots$ & -- & -- & -- & -- & -- & -- & -- \\
\hline -- & -- & 30 & -- & -- & -- & -- & -- & -- & -- & -- & -- & -- & -- \\
\hline-- & -- & 26 & -- & -- & -- & -- & -- & -- & -- & -- & -- & -- & -- \\
\hline-- & -- & 28 & - & -- & -- & -- & -- & -- & -- & -- & -- & -- & -- \\
\hline-- & -- & 34 & -- & -- & -- & -- & -- & -- & -- & -- & -- & 2.0 & -- \\
\hline 360 & .4 & 28 & .2 & 38 & 485 & 444 & -- & .30 & -- & -- & -- & 5.2 & .72 \\
\hline-- & 2.4 & 27 & -- & -- & -- & -- & -- & -- & -- & -- & -- & 5.3 & .73 \\
\hline-- & 2.2 & 28 & -- & -- & -- & -- & -- & -- & -- & -- & -- & 5.2 & .70 \\
\hline-- & 2.2 & 30 & -- & -- & -- & -- & -- & -- & -- & -- & -- & 5.3 & .68 \\
\hline-- & .4 & 27 & -- & -- & -- & -- & -- & -- & -- & -- & -- & 5.3 & .68 \\
\hline 360 & $<1.0$ & 29 & .2 & 41 & 445 & 441 & -- & .03 & -- & -- & -- & 5.0 & .65 \\
\hline 350 & .8 & 29 & .3 & 39 & 444 & 436 & -- & .07 & -- & -- & -- & 5.0 & .76 \\
\hline-- & $<1.0$ & 25 & -- & -- & -- & - & -- & -- & -- & -- & -- & 5.4 & .78 \\
\hline-- & 1.2 & 26 & -- & -- & -- & -- & -- & -- & -- & -- & -- & 5.5 & .80 \\
\hline 340 & $<1.0$ & 25 & .1 & 42 & 435 & 434 & -- & 11 & -- & -- & -- & 5.1 & .77 \\
\hline 350 & .4 & 28 & .2 & 52 & 436 & 454 & -- & .38 & -- & -- & -- & 5.3 & .72 \\
\hline-- & $<1.0$ & 26 & - & -- & -- & -- & -- & -- & -- & -- & -- & 5.3 & .77 \\
\hline-- & .8 & 31 & -- & -- & -- & -- & -- & -- & -- & -- & -- & 5.2 & .95 \\
\hline-- & .4 & 32 & -- & -- & -- & -- & -- & -- & -- & -- & -- & 4.9 & .84 \\
\hline-- & 1.2 & 26 & -- & -- & -- & - & $\ldots$ & -- & -- & -- & -- & 5.1 & .74 \\
\hline -- & 3.2 & 24 & -- & -- & -- & -- & -- & -- & -- & -- & -- & 5.3 & .76 \\
\hline-- & 4.4 & 24 & -- & -- & -- & -- & -- & -- & -- & -- & -- & 4.9 & .70 \\
\hline-- & .2 & 26 & -- & -- & -- & -- & -- & -- & -- & -- & -- & 4.8 & .73 \\
\hline-- & .6 & 29 & -- & -- & -- & -- & -- & -- & -- & -- & -- & 4.7 & .70 \\
\hline-- & .2 & 29 & -- & -- & -- & -- & -- & -- & -- & -- & -- & 4.7 & .69 \\
\hline -- & .2 & 27 & -- & -- & -- & - & -- & -- & -- & -- & -- & 4.9 & .74 \\
\hline -- & .8 & 28 & -- & -- & -- & -- & -- & -- & -- & -- & -- & 5.0 & .68 \\
\hline-- & .2 & 28 & -- & -- & -- & -- & -- & -- & -- & -- & -- & 5.2 & .67 \\
\hline-- & 1.0 & 30 & -- & -- & -- & -- & -- & -- & -- & -- & -- & 5.1 & .62 \\
\hline -- & .6 & 26 & -. & -- & -- & -- & -- & -- & -- & -- & -- & 5.2 & .56 \\
\hline-- & .4 & 27 & -- & -- & -- & -- & -- & -- & -- & -- & -- & 5.5 & .84 \\
\hline 364 & .2 & 28 & -- & -- & -- & -- & -- & -- & -- & -- & -- & 5.1 & 1.1 \\
\hline 371 & 12 & 22 & .2 & 42 & 419 & 466 & $<.01$ & .20 & -- & -- & $<.02$ & 5.1 & -- \\
\hline 357 & $<.1$ & 28 & .2 & 42 & 422 & 422 & $<.01$ & -- & -- & -- & $<.02$ & 4.6 & .56 \\
\hline 370 & 1.2 & 26 & .4 & 43 & 423 & 451 & $<.01$ & -- & -- & -- & $<.02$ & 5.2 & .72 \\
\hline
\end{tabular}


Table 1. Summary of chemical and physical analyses of water from wells completed in the Red River alluvial aquifer, Louisiana, 1965-92--continued

\begin{tabular}{|c|c|c|c|c|c|c|c|c|c|c|c|c|c|}
\hline $\begin{array}{c}\text { Well } \\
\text { no. }\end{array}$ & Date & $\begin{array}{l}\text { Water } \\
\text { level } \\
\text { below } \\
\text { land } \\
\text { sur- } \\
\text { face } \\
\text { (ft) }\end{array}$ & $\begin{array}{l}\text { Depth } \\
\text { of } \\
\text { well, } \\
\text { total } \\
\text { (ft) }\end{array}$ & $\begin{array}{l}\text { Spe- } \\
\text { cific } \\
\text { con- } \\
\text { duct- } \\
\text { ance } \\
(\mu \mathrm{s} / \mathrm{cm})\end{array}$ & $\begin{array}{l}\text { pH, } \\
\text { field } \\
\text { (stand- } \\
\text { ard } \\
\text { units) }\end{array}$ & $\begin{array}{l}\text { Temper- } \\
\text { ature of } \\
\text { water } \\
\left({ }^{\circ} \mathrm{C}\right)\end{array}$ & $\begin{array}{l}\text { Color } \\
\text { (plat- } \\
\text { inum- } \\
\text { cobalt } \\
\text { units) }\end{array}$ & $\begin{array}{l}\text { Hard- } \\
\text { ness, } \\
\text { total } \\
\text { (mg/L } \\
\text { as } \\
\left.\mathrm{CaCO}_{3}\right)\end{array}$ & $\begin{array}{l}\text { Hard- } \\
\text { ness, } \\
\text { noncarb } \\
\text { whole } \\
\text { water } \\
\text { total } \\
\text { fleld } \\
(\mathrm{mg} / \mathrm{L} \text { as } \\
\left.\mathrm{CaCO}_{3}\right)\end{array}$ & $\begin{array}{c}\text { Calcium, } \\
\text { dis- } \\
\text { solved } \\
\text { (mg/L } \\
\text { as Ca) }\end{array}$ & $\begin{array}{l}\text { Magne- } \\
\text { sium, } \\
\text { dis- } \\
\text { solved } \\
\text { (mg/L } \\
\text { as Mg) }\end{array}$ & $\begin{array}{l}\text { Sodium, } \\
\text { dis- } \\
\text { solved } \\
\text { (mg/L } \\
\text { as } \mathrm{Na} \text { ) }\end{array}$ & $\begin{array}{l}\text { Potas- } \\
\text { sium, } \\
\text { dis- } \\
\text { solved } \\
\text { (mg/L } \\
\text { as K) }\end{array}$ \\
\hline \multirow[t]{36}{*}{$\mathrm{CT}-\quad 81$} & $04-21-70$ & -- & 108 & 868 & -- & -- & 7 & 350 & 0 & 88 & 31 & 58 & 2.5 \\
\hline & $09-19-74$ & 14.59 & 108 & 898 & 6.6 & 20.0 & -- & 440 & -- & -- & -- & -- & -- \\
\hline & $10-25-74$ & 17.85 & 108 & 890 & 7.1 & 20.0 & -- & 360 & -- & -- & -- & -- & -- \\
\hline & $11-29-74$ & 9.80 & 108 & 859 & 6.7 & 20.0 & -- & 350 & -- & -- & -- & -- & -- \\
\hline & $12-19-74$ & 6.79 & 108 & 890 & 6.7 & 20.5 & -- & 350 & -- & -- & -- & -- & -- \\
\hline & $01-28-75$ & 6.29 & 108 & 917 & 6.8 & 20.0 & -- & 350 & -- & -- & -- & -- & -- \\
\hline & $04-05-75$ & +0.97 & 108 & 901 & 6.7 & 20.0 & 10 & 350 & 0 & 88 & 32 & 63 & 2.5 \\
\hline & $07-21-75$ & 11.46 & 108 & 917 & 6.8 & 20.0 & 0 & 330 & 0 & 87 & 27 & 70 & 2.5 \\
\hline & $10-29-75$ & 22.28 & 108 & 891 & 6.9 & 20.0 & 0 & 340 & 0 & 90 & 28 & 66 & 3.0 \\
\hline & $03-23-76$ & 11.55 & 108 & 900 & 7.1 & 20.0 & -- & 350 & -- & -- & -- & -- & -- \\
\hline & $06-28-76$ & 18.23 & 108 & 879 & 7.1 & 20.0 & -- & 350 & -- & -- & -- & -- & -- \\
\hline & $10-22-76$ & 25.35 & 108 & 928 & 6.9 & - & 5 & 360 & 0 & 81 & 38 & 65 & 2.7 \\
\hline & $03-30-77$ & 16.50 & 108 & 934 & 7.1 & 20.0 & 10 & 350 & 0 & 96 & 27 & 65 & 3.1 \\
\hline & $09-16-77$ & 25.55 & 108 & 926 & 7.1 & 20.0 & -- & 340 & -- & -- & -- & -- & -- \\
\hline & $03-28-78$ & 17.78 & 108 & 695 & 6.5 & 20.0 & -- & 350 & -- & -- & -- & -- & -- \\
\hline & $09-25-78$ & 26.85 & 108 & 1,080 & -- & -- & -- & 370 & -- & -- & -- & -- & -- \\
\hline & $05-14-79$ & 31.10 & 108 & 862 & -- & -- & -- & 340 & -- & -- & -- & -- & -- \\
\hline & $11-28-79$ & 44.42 & 108 & 826 & -- & -- & -- & 320 & -- & -- & -- & -- & -- \\
\hline & $04-10-80$ & 37.25 & 108 & -- & -- & -- & -- & 320 & -- & -- & -- & -- & -- \\
\hline & $09-19-80$ & 49.74 & 108 & -- & -- & -- & -- & 310 & -- & -- & -- & -- & -- \\
\hline & $04-28-81$ & 49.18 & 108 & -- & -- & -- & -- & 310 & -- & -- & - & -- & -- \\
\hline & $09-28-81$ & 48.80 & 108 & -- & -- & -- & -- & 330 & -- & -- & -- & -- & -- \\
\hline & $04-20-82$ & 40.92 & 108 & -- & -- & -- & -- & 290 & -- & -- & -- & -- & -- \\
\hline & $09-21-82$ & 42.36 & 108 & - & -- & -- & -- & 290 & -- & -- & -- & -- & -- \\
\hline & $04-19-83$ & 33.60 & 108 & - & -- & -- & - & 300 & -- & 72 & 29 & -- & -- \\
\hline & $09-26-83$ & 42.30 & 108 & -- & -- & -- & -- & 320 & -- & 81 & 28 & -- & -- \\
\hline & $03-22-84$ & 13.40 & 108 & -- & 6.8 & 20.0 & -- & 300 & -- & 74 & 27 & -- & -- \\
\hline & $10-23-84$ & 20.00 & 108 & -- & 7.0 & 21.0 & -- & 310 & -- & 70 & 32 & -- & -- \\
\hline & $03-25-85$ & 7.04 & 108 & - & 6.7 & 21.0 & -- & 310 & -- & 75 & 30 & -- & -- \\
\hline & $10-11-85$ & 22.72 & 108 & -- & 7.0 & 21.0 & -- & 290 & -- & 69 & 29 & -- & -- \\
\hline & $04-02-86$ & 14.00 & 108 & -- & 7.1 & 20.0 & -- & 320 & -- & 80 & 30 & -- & -- \\
\hline & $08-28-86$ & 19.03 & 108 & -- & 7.0 & 20.5 & -- & 300 & -- & 75 & 27 & -- & -- \\
\hline & $06-15-87$ & 11.30 & 108 & -- & 6.9 & 20.0 & -- & 310 & -- & 75 & 29 & -- & -- \\
\hline & $06-23-88$ & 18.90 & 108 & 877 & 6.9 & 22.0 & 5 & 280 & -- & 70 & 26 & 80 & 2.3 \\
\hline & $04-20-89$ & 7.61 & 108 & 881 & 7.0 & 20.5 & 10 & 310 & -- & 73 & 30 & 81 & 2.4 \\
\hline & $04-16-90$ & 3.52 & 108 & 844 & 7.2 & 20.5 & 5 & 340 & 0 & 80 & 33 & 72 & 2.6 \\
\hline \multirow[t]{10}{*}{$\mathrm{CT}-96$} & $02-05-76$ & 18.93 & 76 & 1,980 & 7.1 & -- & 5 & 1,000 & 0 & 250 & 92 & 61 & 5.4 \\
\hline & $03-23-76$ & 10.36 & 76 & -- & 6.7 & -- & -- & 940 & -- & -- & -- & -- & -- \\
\hline & $05-28-76$ & 14.66 & 76 & 1,970 & 7.0 & -- & -- & 940 & -- & -- & -- & -- & -- \\
\hline & $06-28-76$ & 16.28 & 76 & 1,940 & 6.9 & -- & 60 & 940 & 300 & 250 & 77 & 76 & 4.4 \\
\hline & $10-22-76$ & 23.31 & 76 & 2,090 & 6.8 & -- & 5 & 980 & 360 & 160 & 140 & 81 & 4.4 \\
\hline & $03-30-77$ & 14.61 & 76 & 2,080 & 7.1 & -- & 20 & 1,000 & 290 & 260 & 95 & 79 & 5.1 \\
\hline & $09-16-77$ & 23.46 & 76 & 2,010 & -- & -- & -- & 970 & -- & -- & -- & -- & -- \\
\hline & $03-28-78$ & 16.19 & 76 & 2,120 & 6.6 & -- & -- & 1,000 & -- & -- & -- & -- & -- \\
\hline & $09-25-78$ & 26.34 & 76 & 2,370 & -- & -- & -- & 1,000 & -- & -- & -- & -- & -- \\
\hline & $04-02-86$ & 14.61 & 76 & -- & 6.9 & -- & -- & 1,150 & -- & 280 & 110 & -- & -- \\
\hline
\end{tabular}


Table 1. Summary of chemical and physical analyses of water from wells completed in the Red River alluvial aquifer, Louisiana, 1965-92--continued

\begin{tabular}{|c|c|c|c|c|c|c|c|c|c|c|c|c|c|}
\hline $\begin{array}{l}\text { Alkalin- } \\
\text { ity, as } \\
\text { calcium } \\
\text { carbonate, } \\
\text { field } \\
(\mathrm{mg} / \mathrm{L} \text { as } \\
\left.\mathrm{CaCO}_{3}\right)\end{array}$ & $\begin{array}{l}\text { Sulfate, } \\
\text { dis- } \\
\text { solved } \\
(\mathrm{mg} / \mathrm{L} \\
\left.\text { as } \mathrm{SO}_{4}\right)\end{array}$ & $\begin{array}{l}\text { Chlo- } \\
\text { ride, } \\
\text { dis- } \\
\text { solved } \\
\text { (mg/L } \\
\text { as } \mathrm{Cl} \text { ) }\end{array}$ & $\begin{array}{l}\text { Fluo- } \\
\text { ride, } \\
\text { dis- } \\
\text { solved } \\
\text { (mg/L } \\
\text { as F) }\end{array}$ & $\begin{array}{l}\text { Silica, } \\
\text { dis- } \\
\text { solved } \\
\text { (mg/L } \\
\text { as } \\
\left.\mathrm{SiO}_{2}\right)\end{array}$ & $\begin{array}{l}\text { Solids, } \\
\text { residue } \\
\text { at } \\
100^{\circ} \mathrm{C} \text {, } \\
\text { dis- } \\
\text { solved } \\
\text { (mg/L) }\end{array}$ & $\begin{array}{l}\text { Solids, } \\
\text { sum of } \\
\text { constit- } \\
\text { uents, } \\
\text { dis- } \\
\text { solved } \\
(\mathrm{mg} / \mathrm{L})\end{array}$ & $\begin{array}{l}\text { Nitro- } \\
\text { gen, } \\
\text { nitrite } \\
\text { dis- } \\
\text { solved } \\
\text { (mg/L } \\
\text { as N) }\end{array}$ & $\begin{array}{l}\text { Nitro- } \\
\text { gen, } \\
\text { nitrate } \\
\text { total } \\
(\mathrm{mg} / \mathrm{L} \\
\left.\text { as } \mathrm{NO}_{3}\right)\end{array}$ & $\begin{array}{l}\text { Nitro- } \\
\text { gen, } \\
\text { nitrite } \\
\text { dis- } \\
\text { solved } \\
\text { (mg/L } \\
\text { as } \mathrm{NO}_{2} \text { ) }\end{array}$ & $\begin{array}{l}\text { Nitro- } \\
\text { gen, } \\
\text { nitrate } \\
\text { dis- } \\
\text { solved } \\
\text { (mg/L } \\
\text { as N) }\end{array}$ & $\begin{array}{l}\text { Nitro- } \\
\text { gen, } \\
\mathrm{NO}_{2}+\mathrm{NO}_{3} \\
\text { dis- } \\
\text { solved } \\
\text { (mg/L } \\
\text { as N) }\end{array}$ & $\begin{array}{l}\text { Iron, } \\
\text { dis- } \\
\text { solved } \\
\text { (mg/L } \\
\text { as Fe) }\end{array}$ & $\begin{array}{l}\text { Manga- } \\
\text { nese, } \\
\text { dis- } \\
\text { solved } \\
\text { (mg/L } \\
\text { as } \mathrm{Mn} \text { ) }\end{array}$ \\
\hline 450 & 0.8 & 28 & 0.4 & 25 & 491 & 509 & -- & 11 & - & -- & -- & 6.8 & 0.60 \\
\hline-- & $<1.0$ & 32 & -- & - & -- & -- & -- & -- & -- & -- & -- & 7.6 & .63 \\
\hline-- & 8.6 & 44 & -- & -- & - & -- & -- & -- & -- & -- & -- & 7.5 & .65 \\
\hline -- & 3.2 & 34 & -- & -- & -- & -- & -- & -- & -- & - & -- & 8.1 & .60 \\
\hline-- & 4.6 & 36 & -- & -- & -- & -- & -- & -- & -- & -- & -- & 7.6 & .60 \\
\hline-- & 3.0 & 34 & -- & - & -- & - & - & -- & -- & -- & -- & 6.8 & .58 \\
\hline 420 & $<1.0$ & 35 & .3 & 35 & 530 & 537 & $<0.01$ & -- & 0.0 & -- & 5.0 & 7.6 & .56 \\
\hline 440 & $<1.0$ & 36 & .2 & 35 & 535 & 527 & -- & .05 & -- & -- & -- & 7.4 & .55 \\
\hline 420 & 2.6 & 39 & .3 & 31 & 520 & 512 & $\cdots$ & .25 & -- & -- & -- & - & .61 \\
\hline-- & $<1.0$ & 35 & -- & -- & -- & - & -- & -- & -- & -- & -- & 7.6 & .65 \\
\hline-- & .6 & 35 & -- & - & -- & -- & -- & -- & -- & -- & -- & 6.8 & .67 \\
\hline 450 & $<1.0$ & 35 & .1 & 36 & 531 & 551 & -- & 23 & -- & -- & -- & 6.3 & .60 \\
\hline 440 & .4 & 36 & .3 & 45 & 521 & 544 & -- & .11 & -- & -- & -- & 7.5 & .58 \\
\hline-- & $<1.0$ & 37 & -- & -- & -- & -- & -- & -- & -- & -- & -- & 7.3 & .59 \\
\hline-- & $<.2$ & 38 & -- & -- & -- & -- & -- & -- & -- & -- & -- & 7.2 & .60 \\
\hline-- & $<.2$ & 39 & -- & -- & -- & -- & -- & -- & -- & -- & -- & -- & .66 \\
\hline-- & $<.2$ & 52 & -- & -- & -- & -- & -- & -- & -- & -- & -- & -- & .57 \\
\hline- & 2.4 & 35 & -- & -- & -- & -- & -- & -- & -- & -- & -- & -- & .47 \\
\hline-- & 1.8 & 31 & -- & -- & -- & -- & -- & -- & -- & -- & -- & -- & .53 \\
\hline- & .4 & 24 & -- & -- & -- & -- & -- & -- & -- & -- & -- & -- & .51 \\
\hline-- & 1.6 & 25 & -- & -- & -- & -- & -- & - & - & -- & -- & -- & .53 \\
\hline-- & .2 & 28 & -- & -- & -- & -- & -- & -- & -- & -- & -- & -- & .58 \\
\hline-- & .2 & 27 & -- & -- & -- & -- & -- & -- & -- & -- & -- & -- & .53 \\
\hline-- & .2 & 21 & -- & -- & -- & -- & -- & -- & -- & -- & -- & -- & .60 \\
\hline-- & .6 & 19 & -- & -- & -- & -- & -- & -- & - & -- & -- & -- & .57 \\
\hline-- & 2.4 & 20 & -- & -- & -- & -- & -- & -- & -- & -- & -- & -- & .51 \\
\hline-- & .6 & 20 & -- & -- & -- & -- & -- & -- & -- & -- & -- & 7.9 & .55 \\
\hline-- & .8 & 19 & -- & -- & -- & -- & -- & -- & -- & -- & -- & 7.2 & .56 \\
\hline-- & .2 & 17 & -- & -- & -- & -- & -- & -- & -- & -- & -- & 7.7 & .58 \\
\hline- & 2.2 & 24 & -- & -- & -- & -- & -- & -- & - & -- & -- & 7.2 & .42 \\
\hline -- & .6 & 19 & -- & -- & -- & - & -- & -- & -- & -- & -- & 7.5 & .52 \\
\hline-- & .4 & 19 & -- & -- & -- & -- & -- & -- & -- & -- & -- & 7.5 & .60 \\
\hline 442 & .2 & 19 & -- & -- & - & -- & -- & -- & -- & -- & -- & 7.1 & .84 \\
\hline 459 & -- & 19 & .2 & 32 & 493 & 530 & $<.01$ & -- & -- & -- & $<.02$ & 6.3 & .92 \\
\hline 461 & .2 & 22 & .3 & 33 & 501 & 527 & $<.01$ & -- & -- & -- & $<.02$ & 7.5 & .69 \\
\hline 468 & 2.6 & 25 & .4 & 34 & 500 & 539 & $<.01$ & -- & -- & -- & $<.02$ & 7.8 & .64 \\
\hline 630 & 220 & 180 & .2 & 44 & -- & 1,240 & -- & 1.1 & - & -- & -- & 8.5 & 3.2 \\
\hline-- & 200 & 180 & -- & -- & -- & -- & -- & -- & -- & -- & -- & 7.9 & 2.6 \\
\hline-- & 150 & 170 & -- & -- & -- & -- & -- & -- & -- & -- & -- & 8.4 & 2.7 \\
\hline 630 & 180 & 180 & .2 & 39 & 1,330 & 1,190 & -- & 6.7 & -- & -- & -- & 7.8 & 2.6 \\
\hline 640 & 240 & 190 & .1 & 36 & 1,260 & 1,250 & -- & 7.8 & -- & -- & -- & 7.7 & 2.7 \\
\hline 750 & 220 & 180 & .2 & 46 & 1,580 & 1,340 & -- & .79 & -- & -- & -- & 8.2 & 2.7 \\
\hline-- & 210 & 170 & -- & -- & -- & -- & -- & -- & -- & -- & -- & -- & 2.3 \\
\hline-- & 290 & 200 & -- & -- & -- & -- & -- & -- & -- & -- & -- & 8.3 & 3.0 \\
\hline-- & 230 & 180 & -- & -- & -- & -- & -- & -- & -- & -- & -- & -- & -- \\
\hline-- & 140 & 220 & -- & -- & -- & -- & -- & -- & -- & -- & -- & 25 & 3.0 \\
\hline
\end{tabular}


Table 1. Summary of chemical and physical analyses of water from wells completed in the Red River alluvial aquifer, Louisiana, 1965-92--continued

\begin{tabular}{|c|c|c|c|c|c|c|c|c|c|c|c|c|c|}
\hline $\begin{array}{c}\text { Well } \\
\text { no. }\end{array}$ & Date & $\begin{array}{l}\text { Water } \\
\text { level } \\
\text { below } \\
\text { land } \\
\text { sur- } \\
\text { face } \\
\text { (ft) }\end{array}$ & $\begin{array}{l}\text { Depth } \\
\text { of } \\
\text { well, } \\
\text { total } \\
\text { (ft) }\end{array}$ & $\begin{array}{l}\text { Spe- } \\
\text { cific } \\
\text { con- } \\
\text { duct- } \\
\text { ance } \\
(\mu \mathrm{s} / \mathrm{cm})\end{array}$ & $\begin{array}{l}\text { pH, } \\
\text { field } \\
\text { (stand- } \\
\text { ard } \\
\text { units) }\end{array}$ & $\begin{array}{l}\text { Temper- } \\
\text { ature of } \\
\text { water } \\
\left({ }^{\circ} \mathrm{C}\right)\end{array}$ & $\begin{array}{l}\text { Color } \\
\text { (plat- } \\
\text { inum- } \\
\text { cobalt } \\
\text { units) }\end{array}$ & $\begin{array}{l}\text { Hard- } \\
\text { ness, } \\
\text { total } \\
\text { (mg/L } \\
\text { as } \\
\mathrm{CaCO}_{3} \text { ) }\end{array}$ & $\begin{array}{l}\text { Hard- } \\
\text { ness, } \\
\text { noncarb } \\
\text { whole } \\
\text { water } \\
\text { total } \\
\text { field } \\
(\mathrm{mg} / \mathrm{L} \text { as } \\
\left.\mathrm{CaCO}_{3}\right)\end{array}$ & $\begin{array}{l}\text { Calcium, } \\
\text { dis- } \\
\text { solved } \\
\text { (mg/L } \\
\text { as Ca) }\end{array}$ & $\begin{array}{l}\text { Magne- } \\
\text { sium, } \\
\text { dis- } \\
\text { solved } \\
\text { (mg/L } \\
\text { as Mg) }\end{array}$ & $\begin{array}{l}\text { Sodium, } \\
\text { dis- } \\
\text { solved } \\
\text { (mg/L } \\
\text { as Na) }\end{array}$ & $\begin{array}{l}\text { Potas- } \\
\text { sium, } \\
\text { dis- } \\
\text { solved } \\
\text { (mg/L } \\
\text { as K) }\end{array}$ \\
\hline \multirow[t]{6}{*}{$\mathrm{CT}-96$} & $08-28-86$ & 19.86 & 76 & -- & 6.8 & -- & -- & 1,100 & -- & 270 & 100 & -- & -- \\
\hline & $06-15-87$ & 11.98 & 76 & -- & 6.9 & -- & -- & 1,110 & -- & 280 & 100 & -- & -- \\
\hline & $09-19-88$ & 20.85 & 76 & 2,110 & 7.0 & -- & 10 & 1,100 & 0 & 280 & 90 & 100 & 4.2 \\
\hline & $04-18-89$ & 7.84 & 76 & -- & 6.9 & 21.0 & 10 & 990 & -- & 250 & 88 & 88 & 5.6 \\
\hline & $03-26-91$ & 10.17 & 76 & 1,930 & 6.9 & 22.0 & 5 & 950 & -- & 250 & 79 & 81 & 4.3 \\
\hline & $04-28-92$ & 12.96 & 76 & 1,910 & 6.8 & -- & -- & 870 & -- & 230 & 71 & 85 & 4.0 \\
\hline \multirow[t]{16}{*}{$R-733$} & $04-23-58$ & -- & 80 & -- & -- & -- & -- & 790 & -- & -- & -- & -- & -- \\
\hline & $10-08-58$ & -- & 80 & -- & -- & 21.0 & -- & 740 & -- & -- & -- & -- & -- \\
\hline & $06-02-67$ & -- & 80 & 1,980 & 6.4 & -- & -- & -- & -- & -- & -- & -- & -- \\
\hline & $07-08-80$ & -- & 80 & 1,060 & -- & -- & -- & 580 & -- & -- & -- & -- & -- \\
\hline & $09-25-81$ & 26.90 & 80 & -- & -- & -- & -- & 600 & -- & -- & -- & -- & -- \\
\hline & $04-16-82$ & 21.63 & 80 & -- & 6.8 & 20.0 & -- & 600 & -- & -- & -- & -- & -- \\
\hline & $09-22-83$ & 25.95 & 80 & -- & 7.5 & -- & -- & 610 & -- & 120 & 76 & -- & -- \\
\hline & $03-14-84$ & 13.22 & 80 & -- & 6.7 & 21.0 & -- & 620 & -- & 120 & 78 & -- & -- \\
\hline & $10-12-84$ & 23.57 & 80 & -- & -- & -- & -- & 620 & -- & 110 & 85 & -- & -- \\
\hline & $03-19-85$ & 11.57 & 80 & -- & 6.9 & 21.5 & -- & 620 & $\cdots$ & 120 & 77 & - & -- \\
\hline & $10-04-85$ & 23.12 & 80 & -- & -- & -- & -- & 650 & -- & 120 & 85 & -- & -- \\
\hline & $04-01-86$ & 18.60 & 80 & -- & 6.9 & -- & -- & 730 & -- & 140 & 92 & -- & -- \\
\hline & $10-30-86$ & 17.94 & 80 & -- & 6.6 & 20.5 & -- & 740 & -- & 140 & 95 & -- & -- \\
\hline & $06-15-87$ & 13.65 & 80 & -- & 6.8 & 20.5 & -- & 760 & -- & 150 & 93 & -- & -- \\
\hline & $07-01-88$ & 20.08 & 80 & 1,390 & 6.8 & 21.0 & 0 & 750 & 100 & 150 & 90 & 80 & 1.8 \\
\hline & $04-16-90$ & 5.18 & 80 & 1,480 & 7.0 & -- & 0 & 720 & -- & 130 & 95 & 75 & 1.6 \\
\hline \multirow[t]{8}{*}{$\mathrm{R}-744$} & $10-08-58$ & -- & 84 & -- & -- & 20.0 & - & 750 & -- & -- & -- & -- & - \\
\hline & $11-03-58$ & -- & 84 & -- & -- & -- & -- & 750 & -- & -- & -- & -- & -- \\
\hline & $06-02-67$ & -- & 84 & 1,810 & 6.3 & -- & -- & -- & -- & -- & -- & -- & -- \\
\hline & $04-14-76$ & 6.65 & 84 & 1,500 & 6.8 & 20.0 & 0 & 690 & 260 & 180 & 58 & 68 & 3.0 \\
\hline & $08-05-76$ & 8.33 & 84 & 1,490 & 7.0 & -- & -- & 690 & -- & -- & -- & -- & -- \\
\hline & $04-14-77$ & 6.75 & 84 & 1,490 & 7.0 & -- & -- & 690 & -- & -- & -- & -- & -- \\
\hline & $10-27-77$ & 8.99 & 84 & 1,480 & 6.8 & -- & 5 & 680 & 240 & 170 & 62 & 66 & 4.3 \\
\hline & $03-30-78$ & 6.95 & 84 & 1,120 & 6.5 & -- & -- & 680 & -- & -- & -- & -- & -- \\
\hline \multirow[t]{14}{*}{. } & $05-17-79$ & 6.25 & 84 & 1,440 & 6.7 & -- & -- & 680 & -- & -- & -- & -- & -- \\
\hline & $10-24-79$ & 9.02 & 84 & -- & 6.7 & 21.0 & -- & 660 & -- & -- & -- & -- & -- \\
\hline & $03-19-80$ & 6.05 & 84 & 1,410 & 7.0 & -- & -- & 650 & -- & -- & -- & -- & -- \\
\hline & $09-24-80$ & 12.27 & 84 & -- & 6.8 & 20.0 & -- & 700 & -- & -- & -- & -- & -- \\
\hline & $04-22-81$ & 12.32 & 84 & -- & 6.6 & 20.0 & -- & 680 & -- & -- & -- & -- & -- \\
\hline & $09-23-81$ & 13.85 & 84 & -- & 6.7 & 20.0 & -- & 700 & -- & -- & -- & -- & -- \\
\hline & $04-15-82$ & 8.29 & 84 & -- & 6.7 & 20.0 & -- & 690 & -- & -- & -- & -- & - \\
\hline & $09-01-82$ & 11.13 & 84 & -- & 6.8 & 20.0 & -- & 690 & -- & -- & -- & -- & -- \\
\hline & $04-20-83$ & 4.08 & 84 & -- & 6.8 & -- & -- & 700 & -- & 180 & 62 & -- & -- \\
\hline & $03-29-85$ & 5.91 & 84 & -- & 6.4 & 21.0 & -- & 620 & -- & 150 & 60 & -- & -- \\
\hline & $10-07-85$ & 8.78 & 84 & -- & 7.1 & 20.0 & -- & 650 & -- & 160 & 60 & -- & -- \\
\hline & $04-03-86$ & 6.96 & 84 & -- & 6.8 & 19.5 & -- & 750 & -- & 180 & 74 & -- & -- \\
\hline & $10-30-86$ & 9.21 & 84 & -- & 6.6 & 20.0 & -- & 710 & -- & 170 & 70 & -- & -- \\
\hline & $06-15-87$ & 6.44 & 84 & -- & 6.8 & 20.0 & -- & 740 & -- & 190 & 65 & -- & -- \\
\hline
\end{tabular}


Table 1. Summary of chemical and physical analyses of water from wells completed in the Red River alluvial aquifer, Louisiana, 1965-92--continued

\begin{tabular}{|c|c|c|c|c|c|c|c|c|c|c|c|c|c|}
\hline $\begin{array}{l}\text { Alkalin- } \\
\text { 1ty, as } \\
\text { calcium } \\
\text { carbonate, } \\
\text { fleld } \\
(\mathrm{mg} / \mathrm{L} \text { as } \\
\left.\mathrm{CaCO}_{3}\right)\end{array}$ & $\begin{array}{l}\text { sulfate, } \\
\text { dis- } \\
\text { solved } \\
(\mathrm{mg} / \mathrm{L} \\
\left.\text { as } \mathrm{SO}_{4}\right)\end{array}$ & $\begin{array}{l}\text { Chlo- } \\
\text { ride, } \\
\text { dis- } \\
\text { solved } \\
\text { (mg/L } \\
\text { as Cl) }\end{array}$ & $\begin{array}{l}\text { Fluo- } \\
\text { ride, } \\
\text { dis- } \\
\text { solved } \\
\text { (mg/L } \\
\text { as F) }\end{array}$ & $\begin{array}{l}\text { sllica, } \\
\text { dis- } \\
\text { solved } \\
\text { (mg/L } \\
\text { as } \\
\mathrm{SiO}_{2} \text { ) }\end{array}$ & $\begin{array}{l}\text { Solids, } \\
\text { residue } \\
\text { at } \\
100{ }^{\circ} \mathrm{C}, \\
\text { dis- } \\
\text { solved } \\
(\mathrm{mg} / \mathrm{L})\end{array}$ & $\begin{array}{l}\text { Solids, } \\
\text { sum of } \\
\text { constit- } \\
\text { uents, } \\
\text { dis- } \\
\text { solved } \\
(\mathrm{mg} / \mathrm{L})\end{array}$ & $\begin{array}{l}\text { Nitro- } \\
\text { gen, } \\
\text { nitrite } \\
\text { dis- } \\
\text { solved } \\
\text { (mg/L } \\
\text { as N) }\end{array}$ & $\begin{array}{c}\text { N1tro- } \\
\text { gen, } \\
\text { nitrate } \\
\text { total } \\
\text { (mg/L } \\
\left.\text { as } \mathrm{NO}_{3}\right)\end{array}$ & $\begin{array}{l}\text { Nitro- } \\
\text { gen, } \\
\text { nitrite } \\
\text { dis- } \\
\text { solved } \\
\text { (mg/L } \\
\text { as } \mathrm{NO}_{2} \text { ) }\end{array}$ & $\begin{array}{l}\text { Nitro- } \\
\text { gen, } \\
\text { nitrate } \\
\text { dis- } \\
\text { solved } \\
\text { (mg/L } \\
\text { as N) }\end{array}$ & $\begin{array}{l}\mathrm{N} 1 \text { tro- } \\
\text { gen, } \\
\mathrm{NO}_{2}+\mathrm{NO}_{3} \\
\text { dis- } \\
\text { solved } \\
\text { (mg/L } \\
\text { as N) }\end{array}$ & $\begin{array}{l}\text { Iron, } \\
\text { dls- } \\
\text { solved } \\
\text { (mg/L } \\
\text { as Fe) }\end{array}$ & $\begin{array}{c}\text { Manga- } \\
\text { nese, } \\
\text { dis- } \\
\text { solved } \\
\text { (mg/L } \\
\text { as } M \text { ) }\end{array}$ \\
\hline-- & 250 & 210 & -- & -- & -- & -- & -- & -- & -- & -- & -- & 13 & 2.6 \\
\hline 747 & 240 & 210 & -- & -- & -- & -- & -- & - & -- & -- & -- & 9.8 & 3.7 \\
\hline 789 & 210 & 180 & 0.4 & 39 & 1,130 & 1,390 & $<0.01$ & -- & -- & -- & 0.03 & 6.0 & 3.1 \\
\hline 767 & 180 & 170 & .2 & 39 & 1,370 & 1,290 & $<.01$ & -- & -- & -- & $<.02$ & 6.1 & 2.8 \\
\hline 788 & 110 & 160 & .2 & 39 & 1,200 & 1,200 & $<.01$ & -- & -- & -- & .02 & 5.9 & 2.1 \\
\hline 782 & 120 & 150 & .2 & 38 & 1,200 & 1,160 & $<.01$ & -- & -- & -- & $<.02$ & 5.5 & 2.0 \\
\hline-- & 350 & 60 & -- & -- & -- & -- & -- & -- & -- & -- & -- & -- & -- \\
\hline -- & -- & 68 & -- & -- & -- & -- & -- & -- & -- & -- & -- & -- & -- \\
\hline - & 350 & -- & -- & -- & -. & -- & -- & -- & - & -- & -. & -- & -- \\
\hline-- & 93 & 26 & -- & -- & -- & -- & -- & -- & -- & -- & -- & -- & .69 \\
\hline-- & 91 & 27 & -- & -- & -- & -- & -- & -- & -- & -- & -- & -- & .65 \\
\hline-- & 80 & 30 & -- & -- & -- & -- & -- & -- & -- & -- & -- & 4.6 & .71 \\
\hline-- & 110 & 32 & -- & -- & -- & -- & -- & -- & -- & - & -- & 3.3 & .72 \\
\hline-- & 120 & 31 & -- & -- & -- & -- & -- & -- & -- & -- & -- & 3.6 & .72 \\
\hline -- & 120 & 34 & -- & -- & -- & -- & -- & -- & -- & -- & -- & 3.4 & .74 \\
\hline-- & 120 & 21 & -- & -- & -- & -- & -- & -- & -- & -- & -- & 3.6 & .78 \\
\hline -- & 82 & 41 & -- & -- & -- & -- & -- & -- & -- & -- & -- & -- & .76 \\
\hline-- & 110 & 33 & -- & -- & -- & -- & -- & -- & -- & - & -- & 3.2 & .84 \\
\hline-- & 120 & 34 & -- & -- & $-\infty$ & - & -- & -- & -. & -- & -- & 3.1 & .96 \\
\hline 628 & 140 & 39 & -- & -- & -- & -- & -- & -- & -- & -- & -- & 4.8 & 1.2 \\
\hline 644 & 150 & 35 & .4 & 29 & 706 & 928 & $<.01$ & -- & -- & -- & .02 & 4.3 & 1.2 \\
\hline 686 & 190 & 35 & .3 & 31 & 946 & 974 & $<.01$ & -- & -- & -- & $<.02$ & 3.7 & 1.2 \\
\hline-- & -- & 150 & -- & -- & -- & -- & -- & -- & -- & -- & -- & -- & -- \\
\hline-- & -- & -- & -- & -- & -- & -- & -- & -- & -- & -- & -- & -- & - \\
\hline-- & 310 & -- & -- & -- & -- & -- & -- & -- & -- & -- & - & -- & -- \\
\hline 430 & 220 & 130 & .3 & 42 & 1,050 & 965 & -- & 0.0 & -- & -- & -- & 6.1 & .23 \\
\hline-- & 210 & 120 & -- & -- & $\cdots$ & $\cdots$ & -- & -- & -- & -- & - & 6.4 & .26 \\
\hline -- & 220 & 120 & -- & -- & -- & -- & - & -- & -- & - & - & 6.8 & .22 \\
\hline 450 & 210 & 120 & .1 & 36 & 995 & 947 & -- & .0 & -- & -- & -- & 6.7 & .25 \\
\hline-- & -- & 140 & -- & -- & -- & -- & -. & - & - & -- & -- & 5.2 & $.2 B$ \\
\hline-- & 190 & 140 & -- & -- & -- & -- & -- & -- & -- & -- & -- & 6.7 & .27 \\
\hline-- & 140 & 120 & -- & -- & -- & -- & -- & -- & -- & -- & -- & 6.2 & .23 \\
\hline-- & 170 & 120 & -- & -- & - & -- & -- & -- & -- & -- & -- & 7.0 & .27 \\
\hline-- & 190 & 130 & -- & -- & -- & -- & -- & -- & -- & -- & -- & 7.2 & .24 \\
\hline-- & 230 & 120 & -- & -- & -- & -- & -- & -- & -- & -- & -- & 7.3 & .26 \\
\hline- & 220 & 120 & -- & -- & -- & -- & -- & -- & -- & -- & - & 7.3 & .25 \\
\hline-- & 180 & 140 & -- & -- & -- & -- & -- & -- & - & -- & -- & 7.5 & .24 \\
\hline -- & 170 & 120 & -- & -- & -- & -. & -- & -- & -- & -- & -- & 7.1 & .25 \\
\hline-- & 230 & 120 & -- & -- & -- & -- & -- & -- & -- & -- & -- & 7.2 & .32 \\
\hline-- & 240 & 140 & -- & -- & -- & -- & -- & -- & -- & -- & -- & 6.8 & .36 \\
\hline-- & 290 & 140 & -- & -- & -- & -- & -- & -- & - & -- & -- & 5.7 & .36 \\
\hline-- & 230 & 130 & -- & -- & -- & -- & -- & - & -- & -- & -- & 7.6 & .46 \\
\hline-- & 200 & 120 & -- & -- & -- & -- & -- & -- & - & -- & -- & 6.9 & .24 \\
\hline 449 & 210 & 130 & -- & -- & -- & -- & -- & -- & -- & -- & -- & 7.4 & .28 \\
\hline
\end{tabular}


Table 1. Summary of chemical and physical analyses of water from wells completed in the Red River alluvial aquifer, Louisiana, 1965-92--continued

\begin{tabular}{|c|c|c|c|c|c|c|c|c|c|c|c|c|c|}
\hline $\begin{array}{c}\text { Well } \\
\text { no. }\end{array}$ & Date & $\begin{array}{l}\text { Water } \\
\text { level } \\
\text { below } \\
\text { land } \\
\text { sur- } \\
\text { face } \\
\text { (ft) }\end{array}$ & $\begin{array}{l}\text { Depth } \\
\text { of } \\
\text { well, } \\
\text { total } \\
\text { (ft) }\end{array}$ & $\begin{array}{l}\text { Spe- } \\
\text { cific } \\
\text { con- } \\
\text { duct- } \\
\text { ance } \\
(\mu s / c m)\end{array}$ & $\begin{array}{l}\mathrm{pH}, \\
\text { field } \\
\text { (stand- } \\
\text { ard } \\
\text { units) }\end{array}$ & $\begin{array}{l}\text { Temper- } \\
\text { ature of } \\
\text { water } \\
\left({ }^{\circ} \mathrm{C}\right)\end{array}$ & $\begin{array}{l}\text { Color } \\
\text { (plat- } \\
\text { inum- } \\
\text { cobalt } \\
\text { units) }\end{array}$ & $\begin{array}{l}\text { Hard- } \\
\text { ness, } \\
\text { total } \\
\text { (mg/I } \\
\text { as } \\
\mathrm{CaCO}_{3} \text { ) }\end{array}$ & $\begin{array}{l}\text { Hard- } \\
\text { ness, } \\
\text { noncarb } \\
\text { whole } \\
\text { water } \\
\text { total } \\
\text { field } \\
(\mathrm{mg} / \mathrm{L} \text { as } \\
\left.\mathrm{CaCO}_{3}\right)\end{array}$ & $\begin{array}{l}\text { Calcium, } \\
\text { dis- } \\
\text { solved } \\
\text { (mg/L } \\
\text { as Ca) }\end{array}$ & $\begin{array}{l}\text { Magne- } \\
\text { sium, } \\
\text { dis- } \\
\text { solved } \\
\text { (mg/L } \\
\text { as Mg) }\end{array}$ & $\begin{array}{l}\text { Sodium, } \\
\text { dis- } \\
\text { solved } \\
\text { (mg/L } \\
\text { as } \mathrm{Na} \text { ) }\end{array}$ & $\begin{array}{l}\text { Potas- } \\
\text { sium, } \\
\text { dis- } \\
\text { solved } \\
\text { (mg/I } \\
\text { as K) }\end{array}$ \\
\hline \multirow[t]{33}{*}{$R-963$} & $11-02-72$ & -- & 60 & 1,060 & -- & -- & -- & 510 & -- & 88 & 71 & $\ldots$ & - \\
\hline & $11-28-72$ & -- & 60 & 1,000 & -- & -- & -- & 540 & -- & 100 & 70 & -- & -- \\
\hline & $12-19-72$ & -- & 60 & 1,100 & -- & -- & -- & 530 & -- & 98 & 70 & -- & -- \\
\hline & $02-14-73$ & -- & 60 & 1,070 & -- & - & -- & 570 & -- & 110 & 71 & -- & -- \\
\hline & $06-19-73$ & -- & 60 & 1,110 & -- & -- & -- & 570 & $\cdots$ & 110 & 72 & -- & -- \\
\hline & $08-08-73$ & -- & 60 & -- & -- & -- & -- & 590 & -- & -- & - & -- & - \\
\hline & $03-25-74$ & 7.60 & 60 & 1,210 & 7.1 & -- & -- & 640 & -- & -- & -- & -- & -- \\
\hline & $02-19-75$ & 5.55 & 60 & 1,160 & 6.9 & 21.0 & -- & 600 & -- & -- & -- & -- & -- \\
\hline & $03-05-75$ & 5.48 & 60 & 1,160 & 6.8 & 20.5 & -- & 600 & -- & -- & $-\cdots$ & -- & -- \\
\hline & $06-17-75$ & 4.18 & 60 & 1,150 & 6.5 & 20.5 & 0 & 580 & 0 & 120 & 67 & 50 & 0.6 \\
\hline & $04-09-76$ & 9.29 & 60 & 1,140 & 6.6 & 20.5 & 5 & 590 & 0 & 130 & 64 & 43 & .7 \\
\hline & $11-01-76$ & 19.48 & 60 & 1,160 & 6.6 & -- & 0 & 530 & 0 & 110 & 62 & 44 & .7 \\
\hline & $04-15-77$ & 7.67 & 60 & 1,130 & 6.9 & -- & - & 580 & 0 & -- & -- & -- & -- \\
\hline & $10-27-77$ & 18.95 & 60 & 1,020 & 6.9 & -- & - & 600 & 50 & 120 & -- & -- & -- \\
\hline & $03-30-78$ & 12.76 & 60 & 953 & 6.9 & -- & -- & 490 & -- & -- & -- & -- & -- \\
\hline & $09-27-78$ & 21.50 & 60 & 862 & 6.9 & -- & -- & 480 & -- & -- & -- & -- & -- \\
\hline & $03-28-79$ & 7.93 & 60 & 902 & 7.0 & -- & -- & 490 & -- & -- & -- & -- & -- \\
\hline & $10-24-79$ & 17.47 & 60 & -- & 6.9 & 21.0 & -- & 530 & -- & -- & -- & -- & -- \\
\hline & $03-19-80$ & 11.58 & 60 & 936 & 6.8 & 20.5 & -- & 500 & -- & -- & -- & -- & -- \\
\hline & $09-23-80$ & 21.07 & 60 & -- & 6.9 & -- & -- & 490 & -- & -- & -- & - & -- \\
\hline & $04-22-81$ & 20.70 & 60 & -- & 6.7 & -- & -- & 490 & -- & -- & -- & -- & -- \\
\hline & $09-23-81$ & 21.60 & 60 & -- & 6.9 & -- & -- & 500 & -- & -- & -- & -- & -- \\
\hline & $04-15-82$ & 18.25 & 60 & -- & 6.9 & -- & -- & 510 & -- & -- & -- & -- & -- \\
\hline & $03-14-84$ & 8.57 & 60 & -- & -- & -- & -- & 510 & -- & 100 & 63 & -- & -- \\
\hline & $06-05-85$ & 11.18 & 60 & -- & 7.1 & 21.0 & -- & 600 & -- & 120 & 73 & -- & -- \\
\hline & $10-04-85$ & 17.70 & 60 & -- & 7.1 & 21.0 & -- & 500 & -- & 88 & 68 & -- & -- \\
\hline & $04-02-86$ & 13.23 & 60 & -- & 7.0 & 20.0 & -- & 570 & -- & 95 & 80 & -- & -- \\
\hline & $08-27-86$ & 16.30 & 60 & -- & 7.1 & 21.0 & -- & 510 & -- & 80 & 75 & -- & -- \\
\hline & $06-15-87$ & 10.35 & 60 & -- & 6.9 & 20.5 & -- & 580 & -- & 110 & 75 & -- & -- \\
\hline & $04-13-89$ & 6.26 & 60 & 866 & 7.0 & 21.0 & 10 & 460 & -- & 77 & 64 & 18 & .5 \\
\hline & $04-16-90$ & 4.51 & 60 & 855 & 7.1 & 21.0 & 0 & 470 & 0 & 84 & 64 & 20 & 1.0 \\
\hline & $03-28-91$ & 9.44 & 60 & 977 & 7.0 & 22.5 & 5 & 497 & -- & 92 & 65 & 32 & $<1.0$ \\
\hline & $04-01-92$ & 5.82 & 60 & 1,030 & 6.9 & 22.0 & -- & 550 & $\cdots$ & 98 & 74 & 35 & .8 \\
\hline \multirow[t]{18}{*}{$\mathrm{R}-1102$} & $04-14-76$ & 6.61 & 127 & 1,680 & 6.9 & 20.0 & 0 & 740 & 300 & 190 & 65 & 90 & 3.2 \\
\hline & $08-05-76$ & 3.30 & 127 & 1,680 & 6.9 & -- & -- & 770 & -- & $-\infty$ & - & -- & - \\
\hline & $04-14-77$ & 6.66 & 127 & 1,670 & 6.9 & 20.0 & -- & 750 & $\cdots$ & -- & -- & -- & -- \\
\hline & $10-27-77$ & 8.93 & 127 & 169 & 6.9 & - & 10 & 750 & 290 & 140 & 96 & 100 & 4.7 \\
\hline & $03-30-78$ & 6.87 & 127 & 1,700 & 6.6 & -- & -- & 850 & -- & - & -- & -- & -- \\
\hline & $09-27-78$ & 10.73 & 127 & 1,630 & 6.9 & -- & -- & 760 & - & -- & -- & -- & - \\
\hline & $05-21-80$ & 4.85 & 127 & -- & 7.0 & 20.0 & -- & 720 & -- & -- & -- & -- & -- \\
\hline & $09-24-80$ & 12.24 & 127 & -- & 7.0 & 20.0 & -- & 720 & -- & -- & -- & -- & -- \\
\hline & $04-22-81$ & 12.27 & 127 & -- & 6.8 & 20.0 & -- & 720 & - & -- & -- & -- & -- \\
\hline & $09-23-81$ & 13.84 & 127 & -- & 6.9 & -- & -- & 720 & -- & -- & -- & -- & -- \\
\hline & $04-15-82$ & 9.24 & 127 & -- & 6.9 & -- & -- & 700 & -- & -- & -- & -- & -- \\
\hline & $09-01-82$ & 11.02 & 127 & -- & 6.9 & - & -- & 680 & -- & -- & -- & -- & -- \\
\hline & $10-07-85$ & 10.38 & 127 & -- & 7.2 & 20.0 & -- & 670 & -- & 170 & 59 & -- & -- \\
\hline & $04-03-86$ & 8.61 & 127 & -- & 7.0 & -- & -- & 730 & -- & 180 & 67 & -- & -- \\
\hline & $08-27-86$ & 9.70 & 127 & -- & 6.8 & 20.5 & -- & 760 & -- & 190 & 70 & -- & -- \\
\hline & $06-15-87$ & 6.46 & 127 & -- & 6.8 & 20.0 & -- & 740 & -- & 190 & 65 & -- & $\cdots$ \\
\hline & $06-28-88$ & 10.09 & 127 & 1,570 & 6.7 & 20.0 & 5 & 730 & 190 & 190 & 62 & 110 & 3.3 \\
\hline & $04-20-90$ & 6.12 & 127 & 1,580 & 7.0 & 20.0 & 5 & 720 & -- & 180 & 66 & 94 & 3.1 \\
\hline
\end{tabular}


Table 1. Summary of chemical and physical analyses of water from wells completed in the Red River alluvial aquifer, Louisiana, 1965-92--continued

\begin{tabular}{|c|c|c|c|c|c|c|c|c|c|c|c|c|c|}
\hline $\begin{array}{l}\text { Alkalin- } \\
\text { 1ty, as } \\
\text { calcium } \\
\text { carbonate, } \\
\text { field } \\
\text { (mg/L as } \\
\left.\mathrm{CaCO}_{3}\right)\end{array}$ & $\begin{array}{l}\text { Sulfate, } \\
\text { dis- } \\
\text { solved } \\
\text { (mg/L } \\
\left.\text { as } \mathrm{SO}_{4}\right)\end{array}$ & $\begin{array}{l}\text { Chlo- } \\
\text { ride, } \\
\text { dis- } \\
\text { solved } \\
\text { (mg/L } \\
\text { as Ci) }\end{array}$ & $\begin{array}{l}\text { Fluo- } \\
\text { ride, } \\
\text { dis- } \\
\text { solved } \\
\text { (mg/L } \\
\text { as F) }\end{array}$ & $\begin{array}{l}\text { Silica, } \\
\text { dis- } \\
\text { solved } \\
\text { (mg/L } \\
\text { as } \\
\mathrm{SiO}_{2} \text { ) }\end{array}$ & $\begin{array}{l}\text { Solids, } \\
\text { residue } \\
\text { at } \\
100{ }^{\circ} \mathrm{C}, \\
\text { dis- } \\
\text { solved } \\
\text { (mg/L) }\end{array}$ & $\begin{array}{l}\text { Solids, } \\
\text { sum of } \\
\text { constit- } \\
\text { uents, } \\
\text { dis- } \\
\text { solved } \\
\text { (mg/L) }\end{array}$ & $\begin{array}{l}\text { Nitro- } \\
\text { gen, } \\
\text { nitrite } \\
\text { dis- } \\
\text { solved } \\
(\mathrm{mg} / \mathrm{L} \\
\text { as } \mathrm{N})\end{array}$ & $\begin{array}{l}\text { Nitro- } \\
\text { gen, } \\
\text { nitrate } \\
\text { total } \\
(\mathrm{mg} / \mathrm{L} \\
\left.\text { as } \mathrm{NO}_{3}\right)\end{array}$ & $\begin{array}{l}\text { Nitro- } \\
\text { gen, } \\
\text { nitrite } \\
\text { dis- } \\
\text { solved } \\
\text { (mg/L } \\
\text { as } \mathrm{NO}_{2} \text { ) }\end{array}$ & $\begin{array}{l}\text { Nitro- } \\
\text { gen, } \\
\text { nitrate } \\
\text { dis- } \\
\text { solved } \\
\text { (mg/L } \\
\text { as } N \text { ) }\end{array}$ & $\begin{array}{l}\mathrm{N} 1 \text { tro- } \\
\text { gen, } \\
\mathrm{NO}_{2}+\mathrm{NO}_{3} \\
\text { dis- } \\
\text { solved } \\
\text { (mg/L } \\
\text { as } \mathrm{N} \text { ) }\end{array}$ & $\begin{array}{l}\text { Iron, } \\
\text { dis- } \\
\text { solved } \\
\text { (mg/L } \\
\text { as Fe) }\end{array}$ & $\begin{array}{l}\text { Manga- } \\
\text { nese, } \\
\text { dis- } \\
\text { solved } \\
\text { (mg/L } \\
\text { as } \mathrm{Mn} \text { ) }\end{array}$ \\
\hline-- & -- & 10 & -- & -- & -- & -- & -- & -- & -- & -- & -- & -- & -- \\
\hline-- & -- & 10 & -- & -- & -- & -- & -- & -- & -- & -- & -- & -- & -- \\
\hline-- & -- & 12 & -- & -- & -- & -- & -- & -- & -- & -- & -- & -- & -- \\
\hline-- & -- & 8.0 & -- & -- & -- & -- & -- & -- & -- & -- & -- & -- & -- \\
\hline-- & -- & 12 & -- & -- & -- & -- & -- & -- & -- & -- & -- & -- & -- \\
\hline-- & -- & 12 & -- & -- & -- & - & -- & -- & -- & -- & -- & -- & -- \\
\hline-- & 46 & 12 & -- & -- & -- & -- & -- & -- & -- & -- & -- & 1.6 & -- \\
\hline-- & 44 & 16 & -- & -- & -- & -- & -- & -- & -- & -- & -- & 3.1 & 1.3 \\
\hline -- & 43 & 16 & -- & -- & -- & -- & -- & -- & -- & -- & -- & 2.8 & .12 \\
\hline 600 & 39 & 14 & 0.4 & 27 & 701 & 681 & -- & 0.36 & -- & -- & -- & -- & 1.6 \\
\hline 600 & 44 & 12 & .5 & 29 & 683 & 686 & - & .53 & -- & -- & -- & 2.6 & 1.6 \\
\hline 580 & 37 & 11 & .2 & 30 & 671 & 649 & -- & 1.4 & -- & -- & -- & 2.0 & 1.6 \\
\hline 630 & 45 & 9.9 & -- & -- & -- & -- & -- & -- & -- & -- & -- & 2.1 & 1.7 \\
\hline 550 & 52 & 6.6 & -- & -- & -- & -- & -- & -- & -- & -- & -- & 1.9 & 1.6 \\
\hline-- & 34 & 5.0 & -- & -- & -- & -- & -- & -- & -- & -- & -- & 1.7 & 1.6 \\
\hline-- & 24 & 4.1 & -- & -- & -- & -- & -- & -- & -- & -- & -- & 1.4 & 1.4 \\
\hline-- & 40 & 4.0 & -- & -- & -- & -- & -- & -- & -- & -- & -- & 2.4 & 1.7 \\
\hline-- & 45 & 7.0 & -- & -- & -- & -- & -- & -- & -- & -- & -- & -- & 1.8 \\
\hline-- & 27 & 5.6 & -- & -- & -- & -- & -- & -- & -- & -- & -- & 1.8 & 1.6 \\
\hline-- & 25 & 2.1 & -- & -- & -- & -- & -- & -- & -- & -- & -- & 1.8 & 1.5 \\
\hline-- & 34 & 2.9 & - & -- & -- & -- & -- & -- & -- & - & -- & 1.9 & 1.6 \\
\hline-- & 28 & 1.8 & -- & -- & -- & -- & -- & -- & -- & -- & -- & 1.8 & 1.6 \\
\hline-- & 28 & 4.2 & -- & -- & -- & -- & -- & -- & -- & -- & -- & 1.8 & 2.2 \\
\hline-- & 30 & 2.1 & -- & -- & -- & -- & -- & -- & -- & -- & -- & -- & 1.7 \\
\hline- & 36 & 4.4 & -- & -- & -- & -- & -- & -- & -- & -- & -- & 1.7 & 1.6 \\
\hline-- & 36 & 5.4 & -- & -- & -- & -- & -- & -- & -- & -- & -- & 2.2 & 2.5 \\
\hline-- & 25 & 3.4 & -- & -- & -- & -- & -- & -- & -- & -- & -- & 1.8 & 1.6 \\
\hline -- & 27 & 1.7 & -- & -- & -- & -- & -- & -- & -- & -- & -- & 2.0 & 1.7 \\
\hline 509 & 31 & 3.2 & -- & -- & -- & -- & -- & -- & -- & -- & -- & 1.9 & 2.0 \\
\hline 474 & 27 & 2.6 & .6 & 27 & 484 & 504 & $<0.01$ & -- & -- & -- & $<0.02$ & 1.6 & 1.1 \\
\hline 497 & 30 & $7 . \dot{4}$ & .4 & 28 & 513 & 536 & $<.01$ & -- & -- & -- & $<.02$ & 1.7 & 1.6 \\
\hline 547 & 26 & 2.0 & .5 & 28 & 560 & -- & $<.01$ & -- & -- & -- & .02 & 2.2 & 2.1 \\
\hline 564 & 44 & 5.4 & .6 & 30 & 594 & 629 & $<.01$ & -- & -- & -- & $<.02$ & 1.8 & 1.6 \\
\hline 440 & 300 & 160 & .3 & 38 & 1,170 & 1,120 & -- & .0 & - & -- & -- & 6.1 & .20 \\
\hline-- & 290 & 140 & -- & -- & -- & -- & -- & -- & -- & -- & -- & 5.7 & .21 \\
\hline-- & 280 & 140 & -- & -- & -- & -- & -- & -- & -- & -- & -- & 5.7 & .20 \\
\hline 460 & 280 & 140 & .1 & 33 & 1,140 & 1,070 & -- & -- & -- & -- & -- & -- & .20 \\
\hline-- & 270 & 150 & -- & -- & -- & -- & -- & -- & -- & -- & -- & 4.7 & .23 \\
\hline-- & 250 & 140 & -- & -- & -- & -- & -- & -- & -- & $-\sim$ & -- & 4.2 & .23 \\
\hline-- & 240 & 140 & -- & -- & -- & -- & -- & -- & -- & -- & -- & 5.8 & .22 \\
\hline-- & 270 & 140 & -- & -- & -- & -- & -- & -- & -- & - & -- & 6.0 & .21 \\
\hline-- & 290 & 140 & -- & -- & -- & -- & -- & -- & -- & -- & -- & 6.0 & .21 \\
\hline-- & 270 & 140 & -- & -- & -- & -- & -- & -- & -- & -- & -- & 6.1 & .18 \\
\hline-- & 280 & 150 & -- & -- & -- & -- & -- & -- & -- & -- & -- & 5.0 & .24 \\
\hline-- & 200 & 130 & -- & -- & -- & -- & $-\infty$ & -- & -- & -- & -- & 4.3 & .24 \\
\hline-- & 200 & 120 & -- & -- & -- & -- & -- & -- & -- & $-\sim$ & -- & 6.7 & .44 \\
\hline-- & 190 & 120 & -- & -- & -- & -- & -- & -- & -- & -- & -- & 7.2 & .24 \\
\hline-- & 260 & 130 & -- & -- & -- & -- & -- & -- & -- & -- & -- & 6.8 & .52 \\
\hline 431 & 200 & 140 & -- & -- & -- & -- & -- & -- & -- & -- & -- & 7.1 & .52 \\
\hline 434 & 260 & 120 & .2 & 35 & 745 & 1,040 & $<.01$ & -- & -- & -- & $<.02$ & 6.9 & .22 \\
\hline 462 & 270 & 140 & .2 & 35 & 1,070 & 1,070 & $<.01$ & -- & -- & -- & $<.02$ & 6.1 & .18 \\
\hline
\end{tabular}

